\title{
ESTUDO DO DANO POR UMIDADE DE MISTURAS DENSAS COM LIGANTES ASFÁLTICOS CONVENCIONAL E MODIFICADO COM POLÍMERO SBS
}

\begin{abstract}
Dissertação apresentada ao Departamento de Engenharia de Transportes da Escola de Engenharia de São Carlos, da Universidade de São Paulo, como parte dos requisitos para obtenção do título de Mestre em Engenharia Civil
\end{abstract}

Área de Concentração: Infraestrutura de Transportes

Orientadora: Profa. Dra. Ana Paula Furlan

São Carlos

Agosto 
AUTORIZO A REPRODUÇÃO TOTAL OU PARCIAL DESTE TRABALHO, POR QUALQUER MEIO CONVENCIONAL OU ELETRÔNICO, PARA FINS DE ESTUDO E PESQUISA, DESDE QUE CITADA A FONTE.

Anitelli, Andre A597e Estudo do dano por umidade de misturas asfálticas
com ligantes asfálticos convencional e modificado com polímero SBS / Andre Anitelli; orientadora Ana Paula Furlan. São Carlos, 2013.

Dissertação (Mestrado) - Programa de Pós-Graduação em Engenharia de Transportes e Área de Concentração em Infra-Estrutura de Transporte -- Escola de Engenharia de São Carlos da Universidade de São Paulo, 2013.

1. Misturas Asfálticas Densas. 2. Envelhecimento em Curto e em Longo Prazo. 3. Propriedades Mecânicas. 4. Suscetibilidade ao Dano por Umidade. 5. Asfaltos Convencionais e Modificados por Polímeros. I. Título. 


\section{FOLHA DE JULGAMENTO}

Candidato: Engenheiro ANDRÉ ANITELLI.

Título da dissertação: "Estudo do dano por umidade de misturas densas com ligantes asfálticos convencional e modificado com polímero SBS".

Data da defesa: 12/08/2013

\section{Comissão Julgadora:}

Profa. Dra. Ana Paula Furlan (Orientadora)

(Escola de Engenharia de São Carlos/EESC)

Prof. Dr. Glauco Túlio Pessa Fabbri

(Escola de Engenharia de São Carlos/EESC)

Prof. Dr. Marcelo de Castro Takeda

(Universidade Federal de São Carlos/UFSCar)

\section{Resultado:}

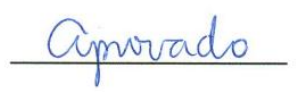

Apovado

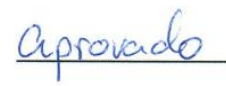

Coordenador do Programa de Pós-Graduação em Engenharia de Transportes: Prof. Associado Antônio Nélson Rodrigues da Silva

Presidente da Comissão de Pós-Graduação:

Prof. Titular Denis Vinicius Coury 


\section{Agradecimentos}

À Profa. Dra Ana Paula Furlan, pela orientação, incentivo, amizade e, sobretudo pela confiança em mim depositada ao longo do desenvolvimento da dissertação, sem os quais certamente este trabalho não teria sido realizado.

Aos meus pais Amauri Anitelli e Elza Maria Gama Anitelli e ao meu irmão Felipe Anitelli, pelo constante apoio e incentivo

À coordenação de Aperfeiçoamento de Pessoal de Nível Superior (CAPES), pela concessão da bolsa de estudos

A todos os professores e técnicos do Departamento de Engenharia de Transportes da EESC-USP. 


\title{
RESUMO
}

\author{
ANITELLI, A. ESTUDO DO DANO POR UMIDADE DE MISTURAS ASFÁLTICAS \\ COM LIGANTES ASFÁLTICOS CONVENCIONAL E MODIFICADO COM \\ POLÍMERO SBS. 2013. 107 p. Dissertação (Mestrado) - Escola de Engenharia de São \\ Carlos, Universidade de São Paulo, São Carlos, 2013.
}

O objetivo desta pesquisa foi contribuir para o entendimento sobre a suscetibilidade ao dano por umidade de misturas asfálticas densas à luz dos ensaios da ASTM D 4867 e AASHTO T 283. Para isso, foi desenvolvido um programa experimental completo que considerou a variação, em dois níveis, dos seguintes fatores: tipo de asfalto (CAP 50/70 e CAP 50/70+SBS), presença de aditivo (sem e com cal) e modo de preparo (envelhecimentos em curto e em longo prazos). O programa experimental resultou em 8 tipos de misturas asfálticas (condições experimentais) que foram caracterizadas em suas propriedades originais e após um condicionamento térmico composto de uma fase de congelamento $\left(-18^{\circ} \mathrm{C}\right.$ por 16 horas) e uma fase de descongelamento $\left(60^{\circ} \mathrm{C}\right.$ por 24 horas $)$. A partir das análises dos resultados foi possível constatar que (i) nenhuma mistura testada foi considerada suscetível ao dano por umidade, mas a relação de resistência à tração das misturas com CAP 50/70 de ambos os métodos se encontraram no limiar dos valores limites; (ii) as misturas com asfalto modificado, em geral, apresentaram maiores valores de módulo de resiliência e resistência à tração e foram mais resistentes à ação da água; (iii) a adição de cal não promoveu mudanças notáveis nas propriedades originais, no entanto contribuiu para a manutenção ou para o aumento da resistência ao dano por umidade; (iv) os envelhecimentos em curto e longo prazos dos métodos da ASTM e da AASHTO não provocaram mudanças importantes nas propriedades originais e após o condicionamento as misturas testadas exibiram tendências de comportamentos similares.

PALAVRAS-CHAVE: Misturas Asfálticas Densas, Envelhecimento em Curto e em Longo Prazo, Propriedades Mecânicas, Suscetibilidade ao Dano por Umidade, Asfaltos Convencionais e Modificados com Polímeros. 
ANITELLI, A. STUDY OF MOISTURE DAMAGE OF CONVENTIONAL AND POLYMER MODIFIED ASPHALT MIXTURES. 2013. 107 p. Thesis (Ms) - Engineering School of São Carlos, University of São Paulo, 2013.

This research presents a contribution to understanding hot mix asphalt (HMA) moisture damage susceptibility according to ASTM D 4867 and AASHTO T 283 tests. A full factorial experiment design was carried out considering the factor variations, on two levels: asphalt type (CAP 50/70 and CAP 50/70+SBS), additive presence (with or without hydrated lime) and mixture procedure (short and long term aging). The experimental program resulted in 8 types of asphalt mixes (experimental conditions) which were characterized by the original properties and after a thermal conditioning wich consisted of a freezing phase $\left(-18{ }^{\circ} \mathrm{C}\right.$ for 16 hours) and a thawing phase $\left(60^{\circ} \mathrm{C}\right.$ for 24 hours). Findings indicate that (i) no one mix was considered susceptible to moisture damage, however the ITR (indirect tensile ratio) of the CAP 50/70 mixes resulted ITR near to protocol admissible values; (ii) in general, CAP 50/70+SBS mixes presented higher resilient modulus, indirect tensile strength and indirect tensile ratio values, (iii) the addition of hydrated lime did not show remarkable changes in original properties, nevertheless it contributed for maintaining or increasing the moisture damage resistance; (iv) short and long term aging procedures (ASTM and AASHTO) did not cause important changes in original properties and after conditioning the mixes showed similar behavior tendencies.

KEY WORDS: Hot Mixture Asphalt, Short and Long Term Aging, Mechanical Properties, Moisture Damage Susceptibility, Conventional and Polymer Modified Asphalts. 


\section{Sumário}

\section{Página}

Agradecimentos V

Resumo VII

Abstract IX

Sumário XI

Lista de Figuras XIII

Lista de Tabelas XV

Lista de Abreviatura e Siglas XVII

1. INTRODUÇÃO E JUSTIFICATIVA

1.1 Considerações Iniciais 19

1.2 Objetivo 21

1.3 Estrutura do Trabalho 21

2. REVISÃO BIBLIOGRÁFICA 23

2.1 Introdução 23

2.2 Adesão, descolamento e dano por umidade 24

2.3 Propriedades dos agregados 26

2.4 Cal como aditivo em misturas asfálticas 28

2.5 Propriedades dos ligantes asfálticos 29

2.6 Propriedade da mistura asfáltica 33

2.7 Ensaios de avaliação da adesividade da mistura asfáltica 35

2.7.1 Ensaios de avaliação visual de adesividade 35

2.7.2 Ensaios de propriedades mecânicas 37

2.7.3 Preparo das misturas asfálticas 38

2.7.3.1 ASTM 38

2.7.3.2 AASHTO 40

3. MATERIAIS E MÉTODOS 43

3.1 Introdução 43 
3.2.1 Agregado___ 45

3.2.2 Ligantes asfálticos__ 46

3.2.3 Aditivos 48

3.3 Métodos _ 49

3.3.1 Programa experimental ___ 49

3.3.2 Teor de asfalto de projeto ___ 49

3.3.3 Absorção de asfalto pelo agregado ___ 51

3.4 Propriedades mecânicas das misturas asfálticas ___ 53

3.4.1 Módulo de resiliência ___ 53

3.4.2 Resistência à tração por compressão diametral____ 55

3.4.3 Ensaios de avaliação da suscetibilidade ao dano por umidade ___ 55

3.4.4 Tratamento dos dados __ 57

4. APRESENTAÇÃO E ANÁLISE DOS RESULTADOS___ 59

4.1. Introdução _ـ 59

4.2. Avaliação das propriedades originais __ 60

4.2.1 Propriedades volumétricas __ 60

4.2.2 Propriedades mecânicas originais ___ 62

4.2.3 Suscetibilidade térmica das misturas asfálticas __ 64

4.2.4 Suscetibilidade ao dano por umidade das misturas asfálticas___ 74

4.3 Avaliação visual___ 79

4.4 Apreciação estatística dos resultados ___ 81

5. CONCLUSÃO _ _ 88

Referências bibliográficas ___ 91

Anexos _ 95 


\section{Lista De Figuras}

Figura 2.1: Relação entre resistência e porcentagem de vazios 34

Figura 2.2: Ensaio de adesividade do agregado graudo 36

Figura 2.3: Ensaio de adesividade do agregado miúdo 36

Figura 3.1: Gráfico de distribuição Granulométrica - Faixa C 46

Figura 3.2: Curvas de Viscosidade versus Temperatura dos Asfaltos 47

Figura 3.3: Volume de Vazios versus Teor de Asfalto 51

Figura 4.1: Absorção de Asfalto pelo Agregado 62

Figura 4.2: MR e RT das Misturas Testadas 64

Figura 4.3: MR versus Temperatura 67

Figura 4.4: Comportamento dos Parâmetros de Rigidez em Função de MR 69

Figura 4.5: RR versus Temperatura 71

Figura 4.6: Atraso versus Temperatura 72

Figura 4.7: RT do grupo de controle e Condicionado 76

Figura 4.8: RRT das Misturas Testadas 77

Figura 4.9: Registro Fotográfico do Plano de Ruptura de CPs 79

Figura 4.10: Efeitos Principais das Variáveis no Valor Médio de MR 83

Figura 4.11: Efeitos Principais das Variáveis no Valor Médio de RT 84

Figura 4.12: Efeitos de Interações das Variáveis no Valor Médio de RT 84

Figura 4.13: Efeitos Principais das Variáveis no Valor Médio de RT 86

Figura 4.14: Efeitos de Interações das Variáveis no Valor Médio de RT 86 


\section{Lista De Tabelas}

Tabela 2.1: Principais procedimentos de ASTM D 4867 e da AASHTO T 283 42

Tabela 3.1: Porcentagem de Massa Retida das Frações de Agregado 45

Tabela 3.2: Absorção dos agregados Grosso e Miúdo 46

Tabela 3.3: Temperatura de Usinagem e Compactação dos Asfaltos 48

Tabela 3.4: Características da Cal 48

Tabela 3.5: Propriedades Volumétricas das Misturas Dosadas 51

Tabela 3.6: Principais procedimentos da ASTM D 4867 e da AASHTO T 283 57

Tabela 4.1: Características Volumétricas das Misturas Asfálticas 60

Tabela 4.2: Absorção de Asfalto pelo Agregado 61

Tabela 4.3: MR e RT das Misturas Testadas $\left(25^{\circ} \mathrm{C}\right)$ 63

Tabela 4.4: Rigidez e Parâmetros de Rigidez das Misturas Produzidas - ASTM 65

Tabela 4.5: Rigidez e Parâmetros de Rigidez das Misturas Produzidas - AASHTO 65

Tabela 4.6: RT e RRT das Misturas Testadas 74 


\section{Lista de Abreviaturas e Siglas}

AASHTO American Association of States Highway and Transportation Officials

ASTM American Society for Testing and Materials

CAP cimento asfáltico de petróleo

CBUQ concreto asfáltico usinado a quente

CGS compactador giratório SUPERPAVE®

cm centímetro

DNER Departamento Nacional de Estradas de Rodagem

DNIT Departamento Nacional de Infraestrutura de Transportes

FI faixa inferior

FS faixa superior

$\mathrm{Gmb}$ densidade aparente

Gmm densidade máxima teórica

Kgf quilograma-força

LVDT linear variable differential transducers

$\mathrm{MPa} \quad$ megapascal

MR módulo de resiliência

MRI módulo instantâneo

MRT módulo total

N número de aplicações de carga

NCHRP National Cooperative Highway Research Program

${ }^{\circ} \mathrm{C} \quad$ graus Celsius

PG performance grade - grau de desempenho

RBV relação betume-vazios

RR recuperação retardada

RT resistência à tração

SBS estireno-butadieno-estireno 
SUPERPAVE® Superior Performing Asphalt Pavements

TUC temperatura de usinagem e compactação

VAM vazios do agregado mineral

Vv volume de vazios 


\section{INTRODUCÃO E JUSTIFICATIVA}

\subsection{Considerações iniciais}

A influência destrutiva da umidade em revestimentos asfálticos tem sido investigada por décadas e ainda hoje ela é um elemento importante a ser discutido. Segundo Kennedy et al. (1983 b), o principal acelerador dos defeitos em misturas asfálticas é a umidade, que pode levar ao descolamento do ligante asfáltico do agregado.

Ensaios de laboratório têm sido desenvolvidos com objetivo de avaliar a suscetibilidade das misturas asfálticas ao dano por umidade e, caso seja identificada esta suscetibilidade, permitir a mudança de algum elemento da mistura para melhorar essa característica, o que pode ser sugerido a partir de mudanças na faixa granulométrica, por exemplo, ou pelo uso de algum aditivo melhorador de adesividade.

Segundo Lottman (1978), os principais mecanismos de ação da água nos revestimentos asfálticos, que levam à perda de ligação adesiva ou descolamento da película de asfalto do agregado, devem-se à pressão provocada pela passagem de veículos, à expansão da água na formação de cristais de gelo, à expansão devida a altas temperaturas e aos ciclos de gelo/degelo, com expansão e contração diferenciais dos materiais.

Condições ambientais como ciclo hidrológico, congelamento/descongelamento e temperatura são fontes que influenciam diretamente no potencial de dano das misturas asfálticas, no entanto merece ser destacada que a ação deletéria da água ocorre se, além de permitida sua 
entrada no sistema, esse volume permanecer aprisionado nos vazios da mistura asfáltica, por isso o volume de vazios é a principal variável associada ao dano por umidade.

Terrel e Al-Swailmi (1993) observaram que apesar das misturas asfálticas com elevada quantidade de vazios, da ordem de $15 \%$, apresentarem maior capacidade de volume de água nos vazios, elas apresentam poucos danos pois são altamente permeáveis e não retém água por muito tempo. Já as misturas asfálticas com baixo volume de vazios, menores que $4 \%$, são praticamente impermeáveis à água.

O intervalo de volume de vazios entre 4 e $8 \%$, onde se encontram a maioria dos concretos asfálticos, foi denominado pelos mesmos autores, Terrel e Al-Swailmi (1993), como vazios péssimos, pois nesse intervalo os vazios não estão totalmente interconectados e a água permanece confinada nos vazios, provocando danos à mistura asfáltica.

O dano causado pela presença de umidade na mistura asfáltica acarreta uma série de consequências que refletem na vida de serviço do revestimento asfáltico, levando a maiores necessidades de intervenções e manutenções (KENNEDY et al., 1983 a). O descolamento do ligante asfáltico do agregado modifica a coesão da mistura e acarreta mudanças de propriedades importantes como a resistência à tração, a rigidez e a flexibilidade. Na tentativa de minimizar os efeitos causados pela água uma série de aditivos pode ser incorporada a mistura asfáltica.

Além dos problemas relativos ao mecanismo de ação da água no material, é complicado fazer um prognóstico do dano que um revestimento asfáltico pode vir a sofrer em serviço, visto que o descolamento não se inicia na superfície de rolamento dos revestimentos asfálticos. Nas últimas décadas, o dano ocasionado pela água tem sido investigado a partir de análises da variação de propriedades mecânicas de misturas asfálticas originais e submetidas a condicionamentos térmicos (LOTTMAN, 1982b). A propriedade que é normalmente relacionada ao descolamento é a resistência a tração

Desta forma é feita uma avaliação da variação da resistência à tração de uma mistura asfáltica que passou por um condicionamento particular e é observada a taxa de retenção da 
propriedade. Alguns pesquisadores que propuseram esse tipo de ensaio estabelecem dois tipos de comportamentos, o das misturas suscetíveis ao dano por umidade, que apresentam taxas de retenção menores que dado valor, e misturas não suscetíveis ao dano por umidade, que apresentam altas taxas de retenção de propriedades. Um dos ensaios mais populares dessa categoria é o AASHTO T 283, que recomenda que a retenção da RT seja superior a $80 \%$ após o condicionamento térmico para ser considerada uma mistura não suscetível a umidade.

Esta pesquisa propõe estudar os efeitos de alguns fatores no dano por umidade de misturas asfálticas densas a partir de duas sistemáticas de ensaio diferentes. Assim pretende-se entender as implicações não somente das variações do tipo de materiais, mas também do uso de procedimentos de ensaios diferentes.

\subsection{Objetivos}

O objetivo principal desta pesquisa é verificar a suscetibilidade ao dano por umidade de misturas asfálticas densas produzidas com diferentes materiais e testar se os procedimentos simuladores do envelhecimento em curto e longo prazos potencializam efeitos do dano por umidade nas misturas asfálticas.

Pretende-se tambem entender o efeito do modo de usinagem ou preparação das misturas asfálticas, a partir da adoção de dois procedimentos laboratoriais utilizados na avaliação do dano por umidade (ASTM D 4867 e AASHTO T 283).

Como objetivo secundário, este trabalho buscou entender a suscetibilidade térmica das misturas asfálticas, tendo como parâmetro de avaliação o módulo de resiliência realizados em diferentes temperaturas.

\subsection{ESTRUTURA DO TRABALHO}

O capítulo 1 desta dissertação relata de uma forma sucinta o problema objeto deste estudo, suas consequências e algumas soluções prévias. 
O capítulo 2 trata da revisão bibliográfica de alguns fatores de influência no dano causado pela umidade na mistura asfáltica e algumas propriedades dos agregados, dos asfaltos, de aditivos e modificadores e das misturas asfálticas. Além disso, é feita uma revisão sobre ensaios de avaliação de adesividade e de dano por umidade de misturas asfálticas.

No capítulo 3 são apresentados os materiais empregados na composição das misturas asfálticas e os métodos utilizados na caracterização dos materiais e das propriedades mecânicas das misturas antes e depois do protocolo de ensaio de dano por umidade.

No capítulo 4 são apresentados e analisados os resultados de ensaios das propriedades mecânicas e de avaliação do dano por umidade da mistura asfáltica. É apresentado um tratamento estatístico dos resultados e a modelação do comportamento de propriedades mecânicas de misturas asfálticas em condições antes e após serem submetidas aos ensaios de dano por umidade.

No capítulo 5 são apresentadas as conclusões dessa pesquisa e algumas sugestões de trabalhos futuros. 


\section{REVISÃO BIBLIOGRÁFICA}

\subsection{Introdução}

Dos defeitos mais comuns que ocorrem na camada asfáltica estão a trinca por fadiga e a deformação permanente. A trinca por fadiga ocorre pela ação das cargas do tráfego devido aos esforços de flexão alternada. Do ponto de vista teórico, o pavimento com maior flexibilidade resiste mais ao trincamento por fadiga, porém outros fatores como condição climáticas/ambientais e características do tráfego também devem ser levados em consideração. No pavimento em serviço, as trincas causadas pela fadiga e não restauradas, permitem a entrada de água no pavimento. Com o passar do tempo e com as solicitações do tráfego, essa umidade pode causar o descolamento e o arrancamento da película de asfalto da mistura e, posteriormente, se não tratada, pode atingir e danificar as camadas subjacentes do pavimento.

A deformação permanente é um defeito que causa a distorção da superfície de rolamento, caracteriza-se por deformações longitudinais que acometem a camada de revestimento asfáltico ou são resultantes da densificação dos materiais ou ruptura de outras camadas do pavimento. As principais causas do afundamento em trilhas de rodas são o excesso de finos e/ou de asfalto na mistura asfáltica, densificação e rupturas das camadas inferiores, mas também pode ser decorrente da compactação inadequada das camadas do pavimento no momento da execução. 
Para melhorar o desempenho da mistura asfáltica e evitar a deformação permanente, é aconselhável a escolha de uma mistura asfáltica mais rígida, porém, para evitar a trinca por fadiga na camada asfáltica de rolamento opta-se por uma camada mais flexível para melhorar a distribuição das tensões. Deste modo, conforme se opta por certo tipo de mistura asfáltica para melhorar uma característica especificamente, pode-se ter potencializado outro defeito, contudo, a melhor solução ou escolha ainda passa pela harmonização das resistências e espessuras das camadas do pavimento

A umidade no pavimento pode levar ao descolamento da película de ligante asfáltico do agregado. Esse efeito acelera os mecanismos de deterioração da deformação permanente e da trinca por fadiga. A variação de temperatura e o ciclo hidrológico pode potencializar a intensidade dos efeitos da água no revestimento asfáltico. A água da chuva pode percolar através dos vazios na mistura asfáltica, e/ou ficar confinada em sua estrutura e, combinada à ação do tráfego, causar danos à mistura asfáltica por excesso de pressão nos poros ou lavagem hidráulica, levando ao desprendimento ou deslocamento da película de asfalto do agregado.

De acordo com Terrel \& Al-Swailmi (1993), o volume de vazios é a principal variável que potencializa o dano causado pela presença de água na mistura asfáltica, porque é neste espaço que a água se aloja ou percola. Como essa característica volumétrica sofre a influência de inúmeros fatores, o estudo do dano por umidade das misturas asfálticas perpassa o entendimento da influência dos materiais que as compõem e das técnicas empregadas na sua produção. Assim, esta pesquisa busca contribuir para o entendimento da importância do papel de diferentes tipos de asfalto, da presença da cal e do envelhecimento na suscetibilidade à umidade de alguns tipos de misturas asfálticas densas.

\subsection{Adesão, coesão e descolamento}

A adesão é consequência da interação físico-química entre o ligante asfáltico e os minerais da superfície do agregado. Essa afinidade que o asfalto apresenta por dado tipo de agregado resulta de interações químicas particulares e podem ser melhores na medida em que a superfície do agregado possua textura rugosa. Uma vez desenvolvida a adesão entre os 
materiais, a ação da água pode, eventualmente, modificar a coesão do material gerado, ou seja, a adesão acontece entre dois materiais diferentes (agregado e asfalto) e a coesão é uma característica da mistura asfáltica.

A ruptura da película adesiva ocorre por haver um plano de ruptura interfacial, completo ou parcial, na ligação entre asfalto e agregado, como falha de recobrimento do agregado pelo asfalto ou presença de umidade na superfície do agregado. Já a ruptura coesiva se caracteriza pela ruptura do ligante.

No que se refere ao dano por umidade, a ruptura da ligação entre asfalto e agregado pode acontecer por (i) descolamento, a água é o agente do deslocamento da película de asfalto; (ii) desprendimento, a presença de umidade na superfície do agregado impede o desenvolvimento de ligações adesivas com o asfalto; (iii) emulsificação, a presença de água no sistema emulsifica o ligante asfáltico (efeito é considerado reversível); (iv) excesso de pressão ou lavagem hidráulica, a água percola sob pressão nos vazios da mistura, descolando a película de asfalto (MAZIDJADEH e BROVOLD, 1968).

A umidade na mistura asfáltica pode causar perda de coesão pela difusão da água no cimento asfáltico o que leva à perda de rigidez e ao descolamento do ligante asfáltico do agregado. A coesão e a adesão estão intimamente ligadas ao desempenho do revestimento asfáltico na vida de serviço.

De acordo com Liberatori (2006) o fenômeno da adesão de um filme de asfalto sobre a superfície de um agregado mineral envolve o desenvolvimento de interações eletrostáticas que dependem fundamentalmente da natureza química do par. A superfície do agregado é heterogênea e contém cargas elétricas que atraem os grupos polares do asfalto, consequentemente, podem acabar atraindo também a umidade. A resistência do filme asfáltico à ação deslocadora da água será maior quanto mais compatíveis forem os materiais.

O deslocamento da película de ligante asfáltico do agregado é causado pela ação da água combinada com as cargas de tráfego e/ou clima. Esse deslocamento é normalmente atribuído à perda da ligação adesiva entre agregado e ligante asfáltico, e ocorre devido ao 
enfraquecimento da ligação adesiva entre o agregado e o filme de ligante asfáltico, provocado pela presença de água no sistema, e consequentemente afeta a coesão da mistura asfáltica (FHWA, 2003).

A suscetibilidade ao dano por umidade indica se a mistura pode apresentar problemas de descolamento devido à ação da água em algum tempo. Esse tipo de avaliação ganhou aceitação a partir de 1970. Consiste da avaliação laboratorial do comportamento da mistura asfáltica compactada frente a mecanismos de simulação que combinam: simulação de envelhecimentos em curto ou em longo prazos da mistura asfáltica, saturação parcial de vazios da mistura por meio de vácuo, esforço de arrancamento da película de asfalto a partir de ciclos térmicos; e, a verificação da mudança do comportamento mecânico da mistura, que normalmente privilegiam a apreciação de propriedades de tração direta ou indireta.

\subsection{Propriedades dos agregados}

Os agregados apresentam características diferentes de composição mineralógica, resistência, durabilidade, sanidade, absorção, forma, angularidade e textura superficial, entre outros. Essas características podem afetar diretamente a ligação entre o asfalto e o agregado, ou seja, a adesão desenvolvida entre os materiais é ligada às características particulares do agregado e do asfalto. A escolha adequada dos materiais é imprescindível para o desenvolvimento da boa ligação adesiva.

Deste modo, por exemplo, a faixa granulométrica influencia diretamente em propriedades mecânicas, hidráulicas e de durabilidade das misturas asfálticas, principalmente nas propriedades mecânicas, porque os agregados fornecem pontos de atrito nos revestimentos e podem, com isso aumentar a resistência da mistura e melhorar a distribuição das cargas do tráfego para as camadas subjacentes (ROBERTS et al., 1991).

Assim, a busca por um agregado de qualidade para ser aplicado em pavimentação deve considerar, dentre outros fatores um material que apresente dureza e resistência para garantir que os esforços aplicados, nos processos construtivos e ao longo da vida em serviço, sejam 
absorvidos e distribuídos sem que haja quebra ou mudança de características de forma do agregado. Assim sendo, é importante lembrar que a dureza reflete na forma final do agregado britado e na sua polaridade, na suscetibilidade ao desgaste, entre outros.

A forma e angularidade do agregado alteram algumas propriedades de resistência e trabalhabilidade de uma mistura asfáltica. Os agregados esféricos podem se movimentar uns sobre os outros quando solicitados e produzem travamentos ruins. Já agregados lamelares podem ser suscetíveis à quebra e com isso aumentar o consumo de asfalto ou o volume de vazios e diminuir a resistência da mistura asfáltica.

Segundo Hicks (1991), Kim et al. (1992) e Kennedy et al. (1983 b) outras características dos agregados devem ser observadas como, por exemplo, absorção. A absorção do asfalto pelo agregado pode não ser favorável ao comportamento das misturas asfálticas, uma vez que diminui a espessura da película de asfalto, tornando-as mais suscetíveis às tensões, ao envelhecimento e ao intemperismo, especialmente a ação da água.

Quanto à capacidade de absorção do agregado, a partir da porosidade de um agregado pode-se inferir se um agregado é mais ou menos absorvente, de modo que quanto maior for a porosidade do material maior será a absorção de asfalto. Quando em viscosidade adequada, o asfalto consegue fluir para dentro da irregularidades e poros do agregado tornando as ligações adesivas mais resistentes devido ao aumento da área superficial disponível (TAYLOR e KHOSLA, 1983).

Também a natureza é imprescindível na seleção do agregado. A identificação da composição mineralógica do agregado permite uma previsão do seu emprego em misturas asfálticas. Os agregados podem ser classificados em três grupos em função do teor de sílica $\left(\mathrm{SiO}_{2}\right)$ : ácidos, intermediários e básicos.

O teor de sílica do agregado pode interferir na qualidade das ligações adesivas, de modo que teores mais altos tornam a superfície do agregado mais ácida, prejudicando o balanceamento de cargas elétricas com os componentes do asfalto (YOON e TARRER, 1988). Normalmente 
os agregados ácidos possuem má adesividade ou interação química fraca com a maioria dos asfaltos (LIBERATORI et al., 2006).

Agregados com alto teor de sílica, como os granitos, são chamados de hidrofílicos, pois apresentam grande afinidade com a água, e agregados com baixos teores de sílica, como os basaltos e os calcários, são chamados de hidrofóbicos. Em geral, os agregados básicos desenvolvem melhor adesividade com asfalto do que os ácidos.

$\mathrm{Na}$ dificuldade de se obter agregados de composição mineralógica adequada para mistura asfáltica, pode-se optar pela utilização de aditivos, cuja função é a de modificar a composição química e elétrica da superfície do agregado ou do ligante asfáltico, e reduzir a tensão superficial entre o ligante asfáltico e o agregado, melhorando o recobrimento do ligante asfáltico na superfície do agregado.

\subsection{Cal como aditivo em misturas asfálticas}

O fíler é o material de enchimento que preenche parte dos vazios da mistura e aumenta sua estabilidade, pode também melhorar o desempenho reológico, mecânico, térmico e de sensibilidade à água da mistura asfáltica. Os fíleres são classificados em inertes, quando é produto da rocha matriz (pó de pedra), ou em ativos, materiais sintéticos e de propriedades diferentes das da rocha que deu origem ao material pétreo (cal, cimento, etc.).

Um dos fíleres ativo mais popular empregado é a cal hidratada. A cal atua como material ativo na mistura asfáltica e altera suas propriedades, melhorando sua trabalhabilidade e sua estabilidade e aumentando sua rigidez e resistência ao envelhecimento e ao dano por umidade. No estudo sobre o efeito da cal na reologia e no envelhecimento da mistura asfáltica, Lesuer et. al (1998) apontam que a cal melhorou as resistências ao dano por umidade e à deformação permanente e reduziu os efeitos de envelhecimento e de fratura em baixas temperaturas das misturas asfálticas. 
Explica-se que cal promove efeitos mais significativos em comparação com outros fíleres, como o cimento e o pó de pedra, porque suas partículas têm dimensões menores, favorecendo algum acúmulo de cal na película de asfalto. Assim, há também mudanças de características reológicas do asfalto. Little e Epps (2001) concluíram que, além da melhora da resistência ao dano por umidade, a adição de cal enrijece o asfalto e a mistura asfáltica, e melhora a resistência ao crescimento de fissuras, em condições de baixas temperaturas,.

Dos aditivos utilizados, a cal é a mais aceita, sendo uma grande aliada ao combate ao dano por umidade na mistura asfáltica. Tunnicliff e Root (1984), Hicks (1991) Little e Epps (2001) constataram que a cal endurece o ligante asfáltico, altera as propriedades dos finos e melhora a estabilidade da mistura. A cal aumenta a resistência ao dano causado pela umidade na mistura, deixa a mistura asfáltica mais rígida e reduz a taxa de oxidação, porém o aumento da rigidez torna a mistura mais vulnerável às trincas por fadiga.

A cal reduz a tensão superficial entre o ligante asfáltico e o agregado. Os íons de cálcio na cal reagem com os ácidos carboxílicos no ligante asfáltico e substituem alguns cátions na superfície agregado, promovendo uma forte ligação entre as moléculas de sílica do agregado e de nitrogênio no ligante asfáltico. Outros efeitos positivos da adição de cal são aumento na viscosidade de asfalto e redução na formação de produtos de oxidação no ligante asfáltico devido ao envelhecimento (MERCADO, 2007).

Lesueur e Little (1998), em seu estudo sobre os efeitos da cal hidratada na mistura asfáltica comenta que a cal hidratada é um aditivo multifuncional bastante promissor para misturas asfálticas. A cal proporciona vários efeitos que levam ao melhoramento da resistência à umidade e redução do descolamento, melhora a resistência à deformação permanente a altas temperaturas por meio do efeito de enchimento, mitiga os efeitos do endurecimento em longo prazo e de fraturas a baixas temperaturas.

\subsection{Propriedades dos asfaltos}

O cimento asfáltico de petróleo (CAP) é produzido a partir de processos de refinamento do petróleo cru e é utilizado para diversos fins, dentre eles, a pavimentação asfáltica. É um 
material termoplástico, de comportamento reológico complexo e dependente de temperatura, que se altera com o intemperismo, perdendo suas propriedades originais (BALBO, 2007).

De acordo com o Manual do Asfalto (1989), os ligantes asfálticos em temperatura ambiente são um material de cor escura, semi-sólido e altamente viscoso, composto principalmente de moléculas complexas de hidrocarbonetos, combinadas com outros átomos, como oxigênio, nitrogênio e enxofre. $\mathrm{O}$ asfalto é classificado como material termoplástico, porque amolece quando aquecido, e enrijece quando resfriado.

A temperatura é um fator muito importante nas características físicas do ligante asfáltico, pois ela altera sua viscosidade; essa característica permite a eficiência das operações de usinagem e compactação. É importante controlar a temperatura no momento da usinagem da mistura, pois somente assim o asfalto se apresenta com baixíssima viscosidade e consegue escoar e recobrir mais facilmente a superfície do agregado.

O asfalto deve envolver e ligar os agregados, não se descolar e resistir à ação do clima e da água. Dos fatores relacionados ao asfalto, a viscosidade é a característica mais frequentemente ligada ao fenômeno de adesão e de absorção. A viscosidade do asfalto pode ser entendida como uma medida de mobilidade molecular e a magnitude das forças atrativas em líquidos e é influenciada diretamente pela temperatura. As forças intermoleculares diminuem em temperaturas mais altas e isso implica em aumento do poder de molhagem, esse processo é o que permite que a asfalto consiga cobrir uma área maior de superfície do agregado. Além disso, o fato do asfalto ter uma viscosidade mais baixa em temperaturas mais altas, pode haver alguma absorção de asfalto pelo agregado (MAZIDJADEH E BROVOLD, 1968).

Em contrapartida, se aquecido em temperaturas mais altas que as recomendadas, há a queima de componentes do asfalto e a mistura apresenta um enrijecimento maior. No que se refere ao revestimento em serviço, há também enrijecimento, contudo o agente causador é a oxidação.

O processo de envelhecimento em revestimentos asfálticos dá-se em duas fases: em curto e em longo prazo. O envelhecimento em curto prazo ocorre no processo de usinagem, quando a mistura é exposta a altas temperaturas resultando na perda de voláteis e na queima de 
componentes orgânicos do asfalto. Com isso o asfalto ganha consistência e a mistura se torna mais rígida, então, em alguns casos, não é incomum entender que algum envelhecimento da mistura asfáltica seja benéfico, pois poderia torná-la mais resistente à deformação permanente e à ação da água, por exemplo. Já o envelhecimento em longo prazo ocorre quando a mistura asfáltica fica exposta às condições climáticas locais e reage com o oxigênio da atmosfera ou sofre a ação da luz (principalmente da radiação ultravioleta).

As condições ambientais podem provocar alterações nas propriedades das misturas asfálticas. Lottman (1978) verificou que os asfaltos de corpos-de-prova produzidos em laboratório apresentaram viscosidade diferentes em relação ao de amostras extraídas de revestimentos em serviço, além disso, constatou a redução da penetração dos asfaltos recuperados dos testemunhos, por consequência do envelhecimento de longo prazo.

Gouveia et al. (2004) verificaram que diferentes modos de preparo de misturas asfálticas resultaram em diferentes taxas de absorção de asfalto pelo agregado. Além disso, constatou-se que as misturas asfálticas cujos agregados apresentaram maiores taxas de absorção de asfalto foram as que apresentaram também maiores valores de módulo de resiliência. Esse aumento de rigidez pode ser entendido considerando que a absorção reduz a espessura da película de asfalto tornando o comportamento da mistura asfáltica mais frágil e também mais sensível a reações oxidativas.

Cerca de $5 \%$ da mistura asfáltica é composta pelo asfalto. O bom desempenho da camada asfáltica em campo está ligado ao bom desenvolvimento da adesão agregado/asfalto e por consequência da coesão da mistura. Para melhorar as características de adesão e coesão, podese também utilizar a alternativa da modificação do asfalto. Dentre os modificadores mais utilizados estão os polímeros (elastômeros, plastômeros entre outros) e agentes rejuvenescedores (como ácidos polifosfóricos).

A modificação pode contribuir para a adequação da viscosidade do asfalto, para melhorar suas propriedades reológicas ou as propriedades mecânicas da mistura, ou, no caso dos ácidos, aumentar a estabilidade à estocagem dos asfaltos modificados por polímeros. É importante destacar que alguns tipos de ácidos (polifosfórico) podem contribuir para o aumento da 
resistência ao dano por umidade, isso pode ser explicado pelo ganho de viscosidade que os asfaltos apresentam quando da sua incorporação.

Já é bastante conhecido que asfaltos mais viscosos apresentam maior resistência ao deslocamento da película na presença da água que os menos viscosos (HICKS, 1991; TAYLOR \& KHOSLA, 1983). Assim, no que se refere aos ligantes modificados, pode-se esperar que o aumento da viscosidade do asfalto causado pela incorporação de polímeros melhore outras características originais, como a flexibilidade e rigidez.

O polímero mais empregado em misturas asfálticas no Brasil é o estireno-butadieno-estireno (SBS). A melhora em algumas características das misturas com asfalto modificado com SBS vem sendo verificada em pesquisas há muito tempo. Azevedo e Filho (2009) citam que foram observadas em misturas asfálticas modificadas com polímeros a redução da suscetibilidade térmica, a melhora nas características adesivas e coesivas da mistura asfáltica, a elevação do ponto de amolecimento, o aumento da resistência à deformação permanente, e as maiores resistências ao desgaste e ao envelhecimento.

Taira et al. (2003), avaliando a suscetibilidade térmica de misturas asfálticas densas com ligantes convencionais e modificados com SBS, concluíram que a temperatura exerce influência significativa nos valores de módulo de resiliência, assim como sua interação com o teor de ligante asfáltico da mistura. Além disso, os autores observaram que a adição do polímero SBS diminuiu a susceptibilidade térmica das misturas asfálticas, principalmente no intervalo de temperaturas próximo ao das de serviço.

Apesar das misturas asfálticas com SBS apresentarem melhora em suas características, o custo ainda é uma questão preocupante. O ácido polifosfórico é um produto relativamente novo, que vem sendo utilizado como agente melhorador de adesividade, catalisador para modificadores poliméricos de asfalto e, além disso, há indícios de que esse produto atue melhorando a susceptibilidade térmica dos asfaltos, além disso a combinação de ácido polifosfórico com polímeros permite reduzir a proporção de polímero a ser adicionada ao ligante asfáltico (LEITE et al., 2004, BUNCHER, 2005, MARTIN e BAUMGARDNER, 2006). 


\subsection{Propriedades das misturas asfálticas}

O volume de vazios é um dos principais fatores que contribuem para o dano por umidade das misturas asfálticas, porém a extensão do dano causado não é proporcional ao aumento de volume de vazios, pois se a mistura asfáltica tiver alto volume de vazios, a água consegue percolar através dos vazios da mistura asfáltica. Por outro lado, se a mistura apresenta baixo volume de vazios, ela se enquadra na condição de material impermeável.

Segundo Mercado (2007), permeabilidade pode ser definida como a capacidade de um material poroso de permitir o fluxo de água através de seus vazios. Este parâmetro tem sido associado à ocorrência de danos causados pela umidade. Estudos mostram que a quantidade de vazios do material, o tamanho e a graduação dos agregados, a quantidade de ligante asfáltico, bem como o modo de compactação são variáveis que afetam a permeabilidade. Ainda segundo o mesmo autor, devido à heterogeneidade da massa asfáltica, nem sempre é fácil desenvolver uma relação direta entre essas variáveis e a permeabilidade. Além disso, as características inerentes à estrutura de vazios como conteúdo, distribuição de tamanho e conectividade também precisam ser considerados.

A figura 2.1 mostra as condições da mistura asfáltica quanto ao volume de vazios. Terrel e Al Swailmi (1993) avaliaram alguns tipos de misturas asfálticas quanto ao dano por umidade e constataram que misturas asfálticas cujo volume de vazios se enquadraram dentro do intervalo de vazios péssimos apresentaram perdas de resistência maiores frente ao condicionamento térmico.

Para Terrel e Al-Swailmi (1993), a condição da mistura asfáltica mais suscetível ao dano por umidade está entre a condição de drenagem livre, com alto volume de vazios, e a condição impermeável, com baixo volume de vazios. Para esses pesquisadores, existem três situações que classificam a mistura asfáltica quanto ao volume de vazios, são elas:

i-) Impermeável ou baixo volume de vazios na mistura $\left(\mathrm{Vv}_{\mathrm{V}}<4 \%\right)$ em conjunção com alto teor de ligante asfáltico; 
ii-) Vazios médios ou péssimos $(4 \% \leq \mathrm{Vv} \leq 13 \%)$, que é a mistura asfáltica de graduação densa;

iii-) Drenagem livre ou graduação aberta (Vv> 13\%), com vazios interconectados.

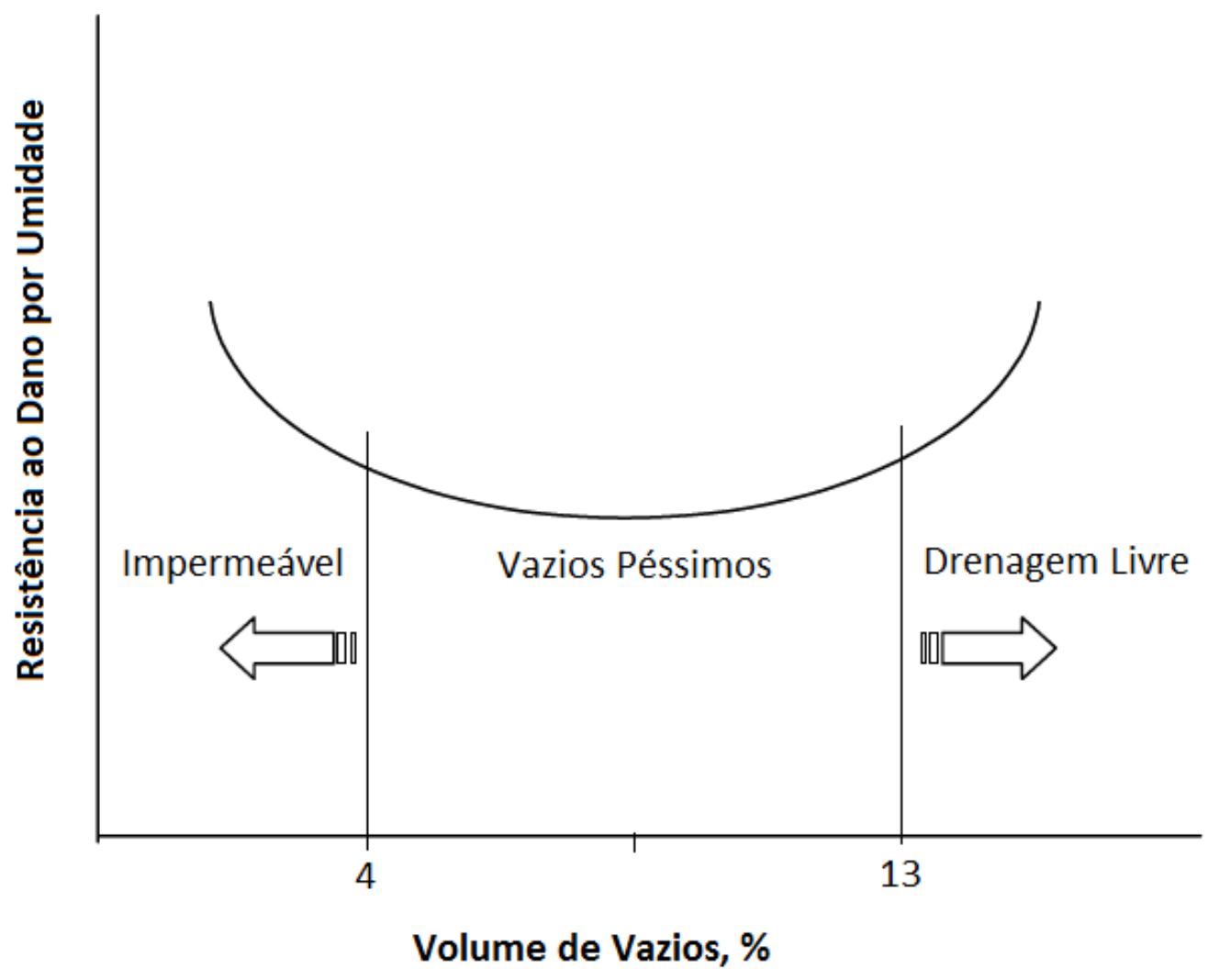

FIGURA 2.1: Relação entre resistência e volume de vazios

(Fonte: TERREL e AL SWAILMI, 1993)

\subsection{Avaliação da adesividade e do dano por umidade em misturas asfálticas}

\subsubsection{Ensaios de avaliação visual de adesividade}

Adesividade de agregado ao material betuminoso é a propriedade que tem o agregado de ser aderido por material betuminoso. Ela é avaliada pelo não descolamento do asfalto que recobre o agregado, quando uma mistura não compactada de agregado-asfalto, em dada fração granulométrica, é imersa em água e soluções de carbonato de sódio ferventes ( DNER-ME 079/94). A avaliação da perda de adesividade do asfalto na fração graúda do agregado é feita a partir da seleção de uma fração granulométrica de agregado que é misturada a dada 
quantidade de asfalto, após o que é feita a imersão da mistura não compactada em água a $40^{\circ} \mathrm{C}$ por um período de 72 horas.

A avaliação é feita de maneira visual, observando-se a ocorrência da exposição da superfície do agregado. No caso do ensaio com agregado graúdo, uma vez identificado qualquer descolamento a mistura é então classificada como não satisfatória. De forma similar, no ensaio com agregados miúdos, quando se observa a exposição da superfície do agregado é feita uma notação da concentração da solução (10 concentrações ao todo) e de acordo com a solução em que foi detectado o descolamento a mistura é classificada como de adesividade: má, satisfatória, boa e ótima.

A figura 2.2 apresenta o aspecto de duas amostras após imersão de um ensaio de adesividade do agregado graúdo, sendo que uma amostra foi considerada de adesividade satisfatória e outra, de adesividade insatisfatória.

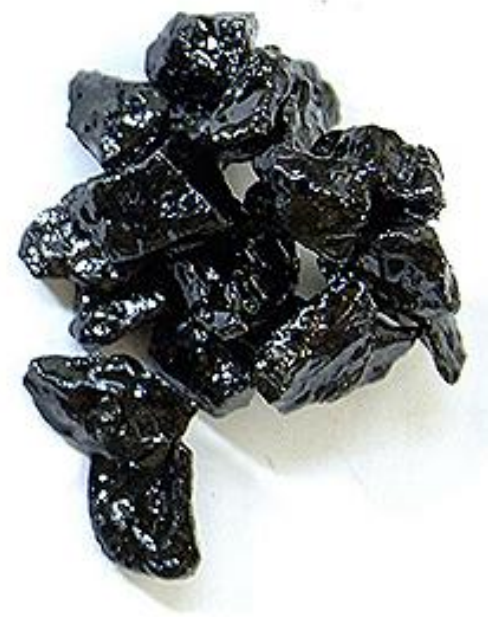

Adesividade satisfatória

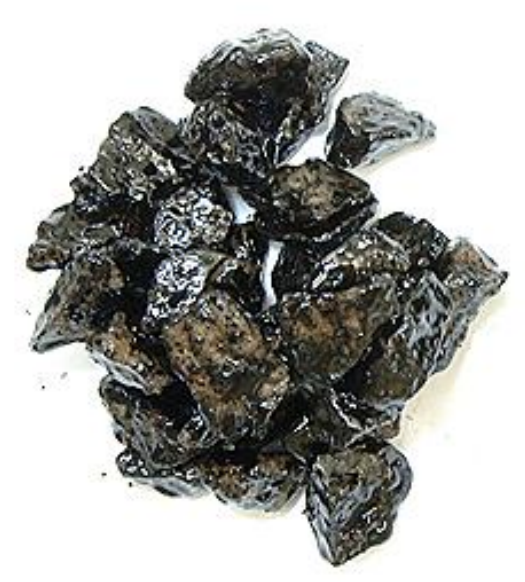

Adesividade Insatisfatória

FIGURA 2.2: Amostras de misturas asfálticas após ensaio de adesividade do agregado graúdo

A figura 2.3 apresenta amostras de misturas asfálticas que passaram pelo ensaio de adesividade do agregado miúdo, com resultado satisfatório, ou seja, não descolamento da película de asfalto (esquerda) e insatisfatório, com descolamento da película de asfalto (direita). 


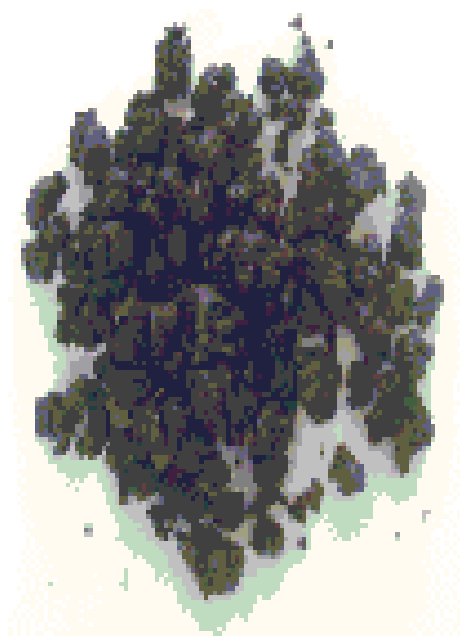

Adesividade Boa

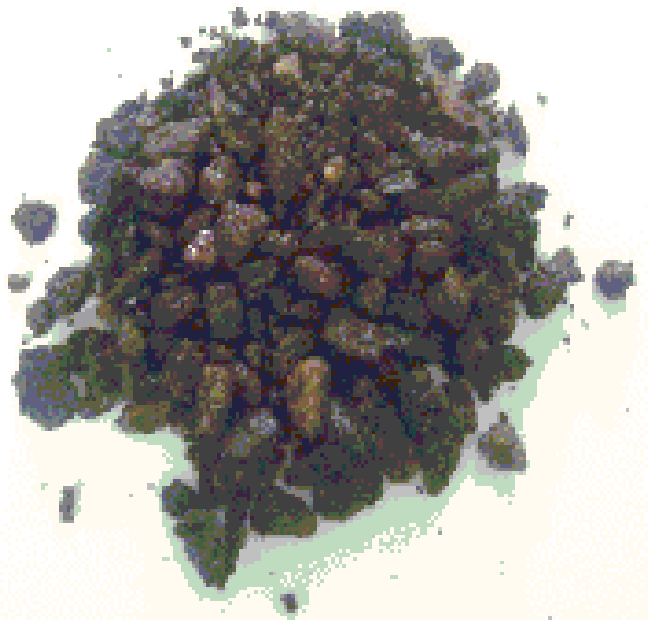

Adesividade má

FIGURA 2.3: Amostras de misturas asfálticas após ensaio de adesividade do agregado miúdo

A facilidade de execução, o baixo custo de equipamentos e a simplicidade de procedimentos são vantagens destes métodos de avaliação. No entanto, em ambos os ensaios não são fornecidos muitas informações a respeito da adesividade, uma vez que o resultado é classificado de acordo com a falha ou não na adesividade.

Os ensaios de adesividade do agregado graúdo e miúdo realizados em laboratório são relativamente rápido, mas divergências nos resultados obtidos podem ser iminentes. No entanto, com os dados obtidos pode-se ter uma análise prévia da necessidade do uso ou não de um aditivo melhorador de adesividade.

\subsubsection{Ensaios de propriedades mecânicas}

Atualmente, os métodos normalizados pela AASHTO e pela ASTM são os procedimentos laboratoriais mais aceitos para a avaliação da sensibilidade das misturas asfálticas ao dano por umidade. Esses métodos têm o objetivo comum de avaliar o dano por umidade em misturas asfálticas compactadas, avaliando a perda de uma propriedade mecânica da mistura asfáltica parcialmente saturada e submetida a algum ciclo simulador esforços de arrancamento da película de asfalto, seja pelo efeito do tráfego ou pela ação de temperaturas diferenciais de congelamento e descongelamento dos materiais. 
A mistura asfáltica é compactada em volumes de vazios recomendados e os corpos de prova são divididos em dois grupos, sendo um grupo tido como o de referência ou de controle, e outro que é submetido à saturação parcial e condicionamento térmico. Em seguida os corpos de prova são submetidos ao ensaio de resistência à tração por compressão diametral. A relação de resistência à tração obtida dos corpos de prova condicionados e não condicionados é dada em porcentagem e indica se a mistura é ou não suscetível ao dano por umidade.

Apesar dos métodos de ensaio AASHTO T 283 e ASTM D 4867 apresentarem alguns procedimentos diferentes, o objetivo final de ambos é avaliar a sensibilidade da mistura asfáltica ao dano por umidade, em longo e curto prazo, respectivamente.

\subsubsection{Preparo de misturas asfálticas da AASHTO T 283 e da ASTM D 4867}

As principais diferenças entre os dois métodos ASTM D 4867 e AASHTO T 283 estão no tipo de condicionamento térmico e no envelhecimento da mistura em longo prazo da AASHTO T 283. Devido ao modo de preparo das misturas asfálticas, convencionou-se classificá-los de ensaios de dano por umidade em longo prazo (AASHTO T283) e em curto prazo (ASTM D4867).

O método da AASHTO T 283 é destinado a avaliar o dano por umidade que as misturas asfálticas devem apresentar em longo prazo, por isso, há no método um procedimento de envelhecimento da mistura asfáltica. Após a mistura do agregado com o ligante asfáltico, a mistura é colocada num recipiente capaz de conter o volume espalhado com uma espessura de uma polegada, onde é deixada para resfriar. Em seguida a mistura asfáltica é colocada numa estufa ventilada a $60^{\circ} \mathrm{C}$ por 16 horas, sendo revolvida de tempos em tempos. Efetuado o procedimento de envelhecimento, a mistura asfáltica não compactada é então aquecida na temperatura de compactação pelo período de 2 horas e compactada até atingir o volume de vazios de $7 \%$. 


\subsubsection{1) ASTM D 4867}

Este método contém procedimentos para testes em concreto asfáltico no propósito de medir o efeito da água na resistência à tração da mistura asfáltica e tem como base os estudos de Tunnicliff e Root (1984). Este método pode ser usado para avaliar a necessidade de incorporação de aditivos melhoradores de adesividade, incluindo aditivos líquidos e sólidos pulverulentos como a cal ou o cimento Portland. No caso de identificada a necessidade de dope ou aditivo, o ensaio permite determinar qual a sua dosagem para maximizar sua eficácia.

Um conjunto de 6 réplicas é dividido em dois subconjuntos. O primeiro grupo é chamado de grupo de controle e o outro grupo de condicionado, pois será submetido à saturação parcial e ao condicionamento térmico antes do ensaio mecânico para medida de propriedade, o que é feito a partir do ensaio de resistência à tração por compressão diametral.

O potencial de dano por umidade é indicado pela relação da resistência à tração (RRT), dada pela divisão da resistência à tração do grupo condicionado e a resistência à tração do grupo de controle, conforme mostrado na expressão 2.1.

$$
R R T=\frac{R T_{\text {condicionado }}}{R T_{\text {controle }}} \times 100
$$

A ASTM D 4867 recomenda um procedimento de preparo da mistura asfáltica, que consiste em estabilizar a temperatura da mistura não compactada por 2 horas, na temperatura de compactação. Após as duas horas em estufa, os CP são então compactados para um volume de vazios de 6 a $8 \%$.

Os corpos de prova do grupo "condicionado" devem ser saturados com água numa bomba de vácuo a $500 \mathrm{mmHg}$ por 5 minutos ou até que a quantidade de água necessária tenha entrado. A saturação recomendada pela norma deve ficar num intervalo de 55 a $80 \%$. Caso o grau de saturação fique abaixo dos 55\%, o CP é novamente submetido à bomba de vácuo, atentando para não ser ultrapassado o tempo de 30 minutos. Por outro lado, se o grau de saturação ficar acima dos $80 \%$, o corpo-de-prova deve ser descartado. 
Os corpos de prova saturados devem ser submetidos a um condicionamento térmico, que consiste da imersão em água a $60^{\circ} \mathrm{C}$ por 24 horas, em seguida, os $\mathrm{CP}$ são imersos num banho em água a $25^{\circ} \mathrm{C}$ para a estabilização da temperatura e, enfim, devem ser realizados os ensaios para a determinação da resistência à tração por compressão diametral. Há na norma a opção de proceder, antes da imersão, o congelamento do $\mathrm{CP}$ a uma temperatura de $-18^{\circ} \mathrm{C}$ por 15 horas seguidas.

A relação de resistência à tração deve ser calculada com base na razão entre a $\mathrm{RT}$ dos corpos de prova do grupo condicionado e do grupo não condicionado. Após terem sido moldados, os corpos de prova grupo não condicionado são armazenados em local com temperatura controlada até que termine o ciclo de condicionamento térmico do grupo condicionado. A fim de padronizar os procedimentos, os ensaios para a determinação de RT são executados nos CP dos dois grupos num mesmo momento. As misturas asfálticas testadas são classificadas como sensíveis ao dano por umidade quando a RRT é menor que $70 \%$.

\subsubsection{2) AASHTO T 283}

O procedimento original para determinação da resistência de misturas asfálticas ao dano por umidade foi desenvolvido por Lottman no final da década de 1970 (LOTTMAN, 1978). O condicionamento incluía a saturação em vácuo por 30 minutos seguido por um período de 30 minutos em pressão atmosférica. As amostras eram congeladas a uma temperatura de $-18^{\circ} \mathrm{C}$ por 15 horas seguidas por 24 horas em banho de água a $60^{\circ} \mathrm{C}$.

Alternativamente Lottman propôs outro tipo de condicionamento térmico, onde para cada ciclo, o corpo de prova era congelado por 4 horas e depois aquecido a $60^{\circ} \mathrm{C}$. Desse modo um ciclo completo durava 8 horas e o condicionamento total incluía 18 ciclos.

O ensaio AASHTO T 283 é uma modificação do ensaio Lottman original. Entre as modificações está a aplicação do vácuo até que se atinja 55\% a $80 \%$ de saturação. Passou-se a utilizar para a determinação de RT a velocidade de $5 \mathrm{~cm} / \mathrm{min}$ e a temperatura de $25^{\circ} \mathrm{C}$ com a 
finalidade de que a prensa Marshall pudesse ser utilizada e para que fosse eliminada a refrigeração para a ruptura dos corpos de prova.

O ensaio AASHTO T 283 tornou-se obrigatório nos procedimentos do método de dosagem Superpave $^{\circledR}$. Apesar de ter se baseado em observações de pavimentos em serviço, o principal problema do AASHTO T 283 é a sua reprodutibilidade e habilidade em prever a suscetibilidade a umidade com confiança razoável (SOLAIMANIAN e KENNEDY, 2000).

Em 1999 foi concluído o estudo "Evaluation of Water Sensivity Tests" que recomenda algumas alterações no método AASHTO T 283 para melhor adaptação ao sistema Superpave $^{\circledR}$. Os pesquisadores investigaram diversos fatores que podem afetar os resultados do ensaio, incluindo diferentes formas de compactação, diâmetro dos corpos de prova, grau de saturação e ciclos de congelamento e descongelamento (LIBERATORI - 2006). Dentre as principais mudanças na norma de 1999 para a de 2003, destacam-se:

i. Para corpos de prova produzidos em laboratório, dimensões de $150 \mathrm{~mm}$ de diâmetro e $63,5 \mathrm{~mm}$ de espessura são normalmente utilizadas. Para tanto, deve ser preparada uma quantidade suficiente de material para produzir os seis corpos de prova dos dois grupos e corpos de prova para determinação do número de giros necessário (para o volume de vazios recomendados) e para determinar a massa específica máxima da mistura, se os valores não são conhecidos.

ii. A parcial saturação dos corpos de prova deve estar contida no intervalo entre 70 a $80 \%$. Para a saturação parcial do corpo de prova compactado é utilizada uma bomba de vácuo na pressão de $500 \mathrm{mmHg}$, que proporciona a entrada de água.

Seguidas as devidas recomendações, o procedimento segue para o condicionamento térmico. Na AASHTO T 283 o condicionamento térmico é composto de um ciclo de congelamento e outro de descongelamento. Após a saturação dos corpos de prova, o ciclo de congelamento é efetuado num freezer à temperatura de $-18{ }^{\circ} \mathrm{C}$ num período de 16 a 18 horas. Ao final das 16 horas, os corpos de prova são então imersos num banho com água à temperatura de $60{ }^{\circ} \mathrm{C}$ por 24 horas. 
Depois de realizado o ciclo de congelamento e descongelamento, os corpos de prova tem sua temperatura estabilizada a $25^{\circ} \mathrm{C}$ por 2 horas e são submetidos a um ensaio de tração por compressão diametral na velocidade de $2 \mathrm{in} / \mathrm{min}$. Ao final do ensaio de resistência à tração, a média das RT dos dois grupos é comparada dividindo a média do grupo condicionado pela média do grupo de controle, semelhante à expressão 2.1 do método da ASTM D 4867.

Para misturas dosadas a partir do método Marshall, a relação de resistência à tração inferior a $70 \%$ indica que a mistura é suscetível ao dano por umidade. Para misturas produzidas a partir do método de dosagem Superpave ${ }^{\circledR}$, o critério de RRT $\leq 80 \%$ indica misturas suscetíveis.

A Tabela 2.1 mostra um resumo dos principais procedimentos das normas ASTM D 4867 e AASHTO T 283.

Tabela 2.1: Principais procedimentos da ASTM D 4867 e da AASHTO T 283

\begin{tabular}{|c|c|c|c|c|c|c|}
\hline Norma & $\begin{array}{l}\mathbf{V v} \\
(\%)\end{array}$ & Envelhecimento & Saturação & \multicolumn{2}{|c|}{ Ciclo térmico } & RRT \\
\hline $\begin{array}{l}\text { ASTM } \\
(1999)\end{array}$ & $6-8 \%$ & Não há & $\begin{array}{c}\text { Vácuo: } \\
500 \text { mmHg } \\
\text { por } 5 \text { minutos } \\
\text { Saturação: } \\
55-80 \%\end{array}$ & $\begin{array}{c}-18^{\circ} \mathrm{C} \text { por } 16 \\
\text { horas }\end{array}$ & $\begin{array}{c}\text { Aquecimento } \\
60^{\circ} \mathrm{C} \text { por } 24 \\
\text { horas }\end{array}$ & $70 \%$ \\
\hline $\begin{array}{l}\text { AASHTO } \\
(2003)\end{array}$ & $6-8 \%$ & $\begin{array}{c}\text { Mistura não } \\
\text { compactada } 60^{\circ} \mathrm{C} \\
\text { por } 16 \text { horas }\end{array}$ & $\begin{array}{c}\text { Vácuo: } \\
500 \text { mmHg } \\
\text { por } 5 \text { minutos } \\
\text { Saturação: } \\
70-80 \%\end{array}$ & $\begin{array}{c}\text { Congelamento } \\
\text { opcional }\end{array}$ & $\begin{array}{c}60^{\circ} \mathrm{C} \text { por } 24 \\
\text { horas }\end{array}$ & $80 \%$ \\
\hline
\end{tabular}




\section{MATERIAIS E MÉTODOS}

\subsection{INTRODUÇÃO}

Neste capítulo são apresentados os materiais utilizados nesta pesquisa, suas caracterizações, e os procedimentos laboratoriais que foram necessários para a apreciação do dano por umidade das misturas asfálticas. O programa experimental consistiu da observação e da comparação de propriedades volumétricas e mecânicas de diferentes misturas asfálticas, avaliadas à luz de dois diferentes procedimentos de avaliação de dano por umidade, o método de ensaio da AASHTO T 283 e o da ASTM D 4867.

O programa fatorial da pesquisa é resultado da variação dos fatores selecionados:

(i) tipo de asfalto, variando em dois níveis, um em que se empregou um CAP convencional e outro um CAP modificado com polímero;

(ii) presença ou não de aditivo, variando em dois níveis, um em que as misturas asfálticas não tiveram a adição de aditivo e outro em que as misturas tiveram a adição de cal hidratada, e;

(iii) tipo de preparo da mistura asfáltica, variando em dois níveis, um que as misturas asfálticas foram submetidas ao envelhecimento em curto prazo (como recomendado pela norma ASTM) e outro que em as misturas asfálticas foram submetidas ao envelhecimento em longo prazo (com recomendado pela norma da AASHTO). 
Cada um dos níveis adotados para os fatores do programa experimental teve por objetivo responder questões particulares. A consideração do fator "tipo de asfalto", representada pelo emprego de um asfalto convencional e um modificado com polímero, pretendeu entender se a modificação do ligante com o polímero provocaria mudanças importantes na sensibilidade das misturas asfálticas frente à ação da água. Para isso, foi necessário selecionar um asfalto modificado que tivesse sido produzido a partir do mesmo asfalto de base.

O fator "aditivo", representado pela presença ou não de cal, buscou entender não somente se a cal reduziria a suscetibilidade à umidade das misturas asfálticas, mas também, se haveria algum problema decorrente da interação da cal com asfalto modificado que levasse a constatar comportamentos mecânicos e de durabilidade indesejáveis.

O fator "tipo de preparo" da mistura, representado pelo tipo de envelhecimento a que a mistura asfáltica é submetida antes da compactação, objetivou observar se os ensaios apresentam a mesma tendência de resultados e se o emprego de diferentes materiais, como as misturas com asfalto modificado com polímero apresentariam comportamentos similares ou superiores quando comparados aos das misturas asfálticas produzidas com asfaltos convencionais.

Oportunamente foram realizados ensaios para a determinação do módulo de resiliência (MR) em diferentes temperaturas para a avaliação da suscetibilidade térmica das misturas asfálticas. Assim sendo, foram determinados os MR nas temperaturas de 10,25 e $40{ }^{\circ} \mathrm{C}$, a fim de se levantar uma curva de variação de rigidez dos materiais quanto à variação de temperatura. Além de fornecer um modo alternativo de avaliação e melhorar a compreensão sobre o comportamento dos materiais, esse tipo de avaliação teve por objetivo tentar relacionar as suscetibilidades térmica e ao dano por umidade das misturas testadas.

A partir dos fatores e níveis adotados, foi possível desenvolver um experimento fatorial completo envolvendo 3 fatores que, variando em 2 níveis, resultou em 8 condições experimentais. Com a necessidade de produzir 6 réplicas por condição experimental, então 
foram produzidos no total 48 corpos de provas, sem considerar aqueles necessários para a dosagem das misturas asfálticas.

A seguir, neste capítulo, são apresentadas as descrições das características dos materiais e dos métodos aplicados nesta pesquisa.

\subsection{MATERIAIS}

\subsubsection{Agregado}

O agregado utilizado nesta pesquisa é um agregado de natureza granítica, que foi fornecido pela pedreira São Jerônimo, localizada na cidade de Valinhos, SP. Após a coleta do material, o agregado foi lavado e seco, separado e manipulado a fim de ser enquadrado na curva de distribuição granulométrica representada pelo centro da faixa C do DNIT, conforme apresentado na tabela 3.1 e na figura 3.1.

TABELA 3.1: Porcentagens de massa retida das frações de agregado para enquadramento no centro da faixa $\mathrm{C}$ do DNIT

\begin{tabular}{ccccc}
\hline $\begin{array}{c}\text { Abertura da } \\
\text { peneira }(\mathbf{m m})\end{array}$ & $\begin{array}{c}\text { \% Retida } \\
\text { Limite Inferior }\end{array}$ & $\begin{array}{c}\text { \% Retida } \\
\text { Limite Superior }\end{array}$ & Centro da Faixa & $\begin{array}{c}\text { Quantidade } \\
\text { por CP (g) }\end{array}$ \\
\hline $19,10-12,70$ & 20 & 0 & 10 & 120 \\
$12,70-9,52$ & 10 & 10 & 10 & 120 \\
$9,52-4,76$ & 26 & 18 & 22 & 264 \\
$4,76-2,00$ & 22 & 22 & 22 & 264 \\
$2,00-0,42$ & 14 & 24 & 19 & 228 \\
$0,42-0,177$ & 4 & 10 & 7 & 84 \\
$0,177-0,074$ & 2 & 6 & 4 & 48 \\
$0,074-$ Fundo & 2 & 10 & 6 & 72 \\
\hline TOTAL & $100 \%$ & $100 \%$ & $100 \%$ & $1200 \mathrm{~g}$ \\
\hline
\end{tabular}




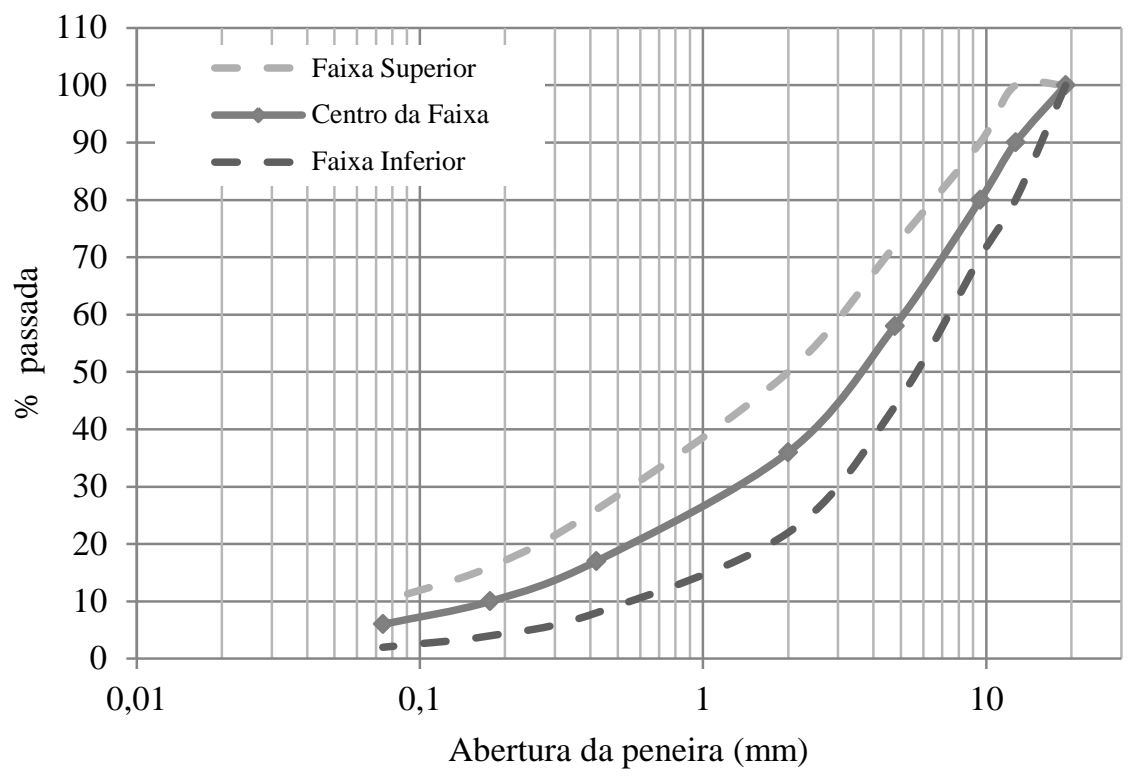

FIGURA 3.1: Gráfico de distribuição granulométrica da faixa "C" do DNIT

Depois do procedimento de enquadramento, foram separadas as quantidades de agregado necessárias para a produção de corpos de prova de 1.200 gramas e acondicionados em sacos plásticos para uso posterior em dosagem e moldagem.

O agregado granítico foi submetido aos ensaios das densidades aparente e real dos agregados grossos e finos (ASTM 127/01 e 128/01). Os resultados da massa específica aparente, massa específica real a da absorção são apresentados na tabela 3.2.

TABELA 3.2: Absorção dos agregados grosso e miúdo

\begin{tabular}{lccc}
\cline { 2 - 4 } & $\begin{array}{c}\text { Massa Específica Aparente } \\
\left(\mathbf{g} / \mathbf{c m}^{\mathbf{3}}\right)\end{array}$ & $\begin{array}{c}\text { Massa Específica Real } \\
\left(\mathbf{g} / \mathbf{c m}^{\mathbf{3}}\right)\end{array}$ & $\begin{array}{c}\text { Absorção de água } \\
(\mathbf{\%})\end{array}$ \\
\hline Agregado Grosso & 2,599 & 2,756 & 0,61 \\
Agregado Fino & 2,562 & 2,576 & 2,58 \\
\hline
\end{tabular}

\subsubsection{Ligantes asfálticos}

Foram utilizados dois tipos de ligantes asfálticos, um CAP 50/70 e esse mesmo CAP 50/70 modificado com polímero SBS, denominado comercialmente de Stylink ${ }^{\circledR}$ (que tem sua 
especificação por grau de desempenho como PG 76-22). Ambos os asfaltos foram cedidos pela empresa Betunel Indústria e Comércio Ltda., localizada na cidade de Ribeirão Preto, SP.

Para a caracterização dos asfaltos, foram realizados ensaios de viscosidade Brookfield de acordo com a norma ASTM D4402-02. Assim, foi possível a determinação da curva de viscosidade versus temperatura, apresentada na figura 3.2. Nela se observa que o asfalto modificado (Stylink ${ }^{\circledR}$ ) exibiu, em geral, para iguais temperaturas, viscosidade maior que as do asfalto convencional (CAP 50-70).

A partir dos resultados dos ensaios de viscosidade, foram determinadas as temperaturas ideais de aquecimento dos asfaltos para usinagem (mistura) e compactação da mistura asfáltica. A ASTM D 4402 recomenda que a temperatura de usinagem do asfalto seja aquela em que apresente viscosidade de 0,17 \pm 0,02 Pa.s, já para temperatura de compactação, a viscosidade deve ser de 0,28 \pm 0,03 Pa.s. A norma recomenda que a temperatura do agregado na usinagem esteja entre 10 a $15^{\circ} \mathrm{C}$ acima da temperatura asfalto. A Tabela 3.3 apresenta as faixas de temperaturas de usinagem e compactação dos asfaltos testados.

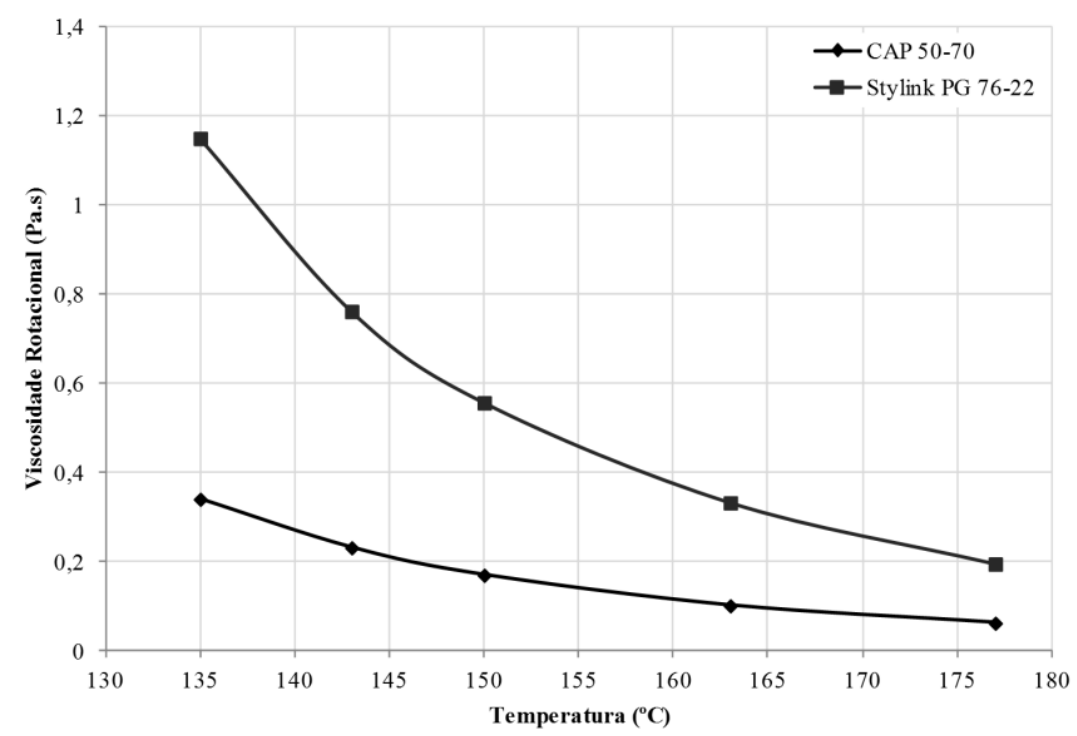

FIGURA 3.2: Curvas de viscosidade versus temperatura dos asfaltos testados

TABELA 3.3: Temperaturas de usinagem e compactação dos asfaltos 


\begin{tabular}{lcc}
\cline { 2 - 3 } & $\begin{array}{c}\text { Intervalo de temperatura }\left({ }^{\mathbf{0}} \mathbf{C}\right) \\
\text { Usinagem }\end{array}$ & $\begin{array}{c}\text { para operações de } \\
\text { Compactação }\end{array}$ \\
\hline CAP 50/70 & 147 a 153 & a 142 \\
CAP 50/70+SBS & 178 a 182 & 165 a 171 \\
\hline
\end{tabular}

Para a operação de usinagem, foram utilizadas as temperaturas de $150{ }^{\circ} \mathrm{C}$ e $180{ }^{\circ} \mathrm{C}$ para o aquecimento do CAP 50/70 e CAP 50/70+SBS, respectivamente. Já para a operação de compactação, foram utilizadas as temperaturas de $140{ }^{\circ} \mathrm{C}$ e $168{ }^{\circ} \mathrm{C}$ para o aquecimento do CAP 50/70 e CAP 50/70+SBS, respectivamente. Essas temperaturas representam a média do intervalo de temperatura das operações.

\subsubsection{Aditivos}

Para este trabalho o aditivo selecionado foi uma cal hidratada cálcica tipo CH1 (Supercal®), cuja composição se enquadra aos valores dos intervalos apresentados na Tabela 3.4. A cal foi acrescentada aos agregados pouco antes da compactação dos corpos-de-prova. A quantidade de cal adicionada ao agregado foi de 1,5\%.

TABELA 3.4: Características da cal utilizada (Fonte: Supercal®)

\begin{tabular}{lc}
\hline Componentes & Intervalos (\%) \\
\hline $\mathrm{CaO}$ & 70 a 74 \\
$\mathrm{MgO}$ & 0,1 a 1,4 \\
$\mathrm{Insolúvel} \mathrm{em} \mathrm{HCl}$ & 0,5 a 2,5 \\
$\mathrm{Fe}_{2} \mathrm{O}_{3}+\mathrm{Al}_{2} \mathrm{O}_{3}$ & 0,2 a 0,8 \\
$\mathrm{Perda}^{2}$ ao fogo & 23 a 27 \\
$\mathrm{CO}_{2}(\%)$ & 1,5 a 3,5 \\
$\mathrm{SO}_{3}(\%)$ & 0,1 a 0,0 \\
$\mathrm{CaO}+\mathrm{MgO}$ Base de não-volátil (\%) & - \\
$\mathrm{MgO} \mathrm{Não} \mathrm{hidratado}$ & 0,5 a 1,8 \\
\hline
\end{tabular}

\subsection{MÉTODOS}

\subsubsection{Programa experimental}

O programa de experimentos desta pesquisa foi desenvolvido a fim de entender o efeito de alguns fatores preponderantes na suscetibilidade ao dano por umidade de misturas asfálticas. 
Convenientemente, outra pesquisa focando deformação permanente de misturas asfálticas está ligada a esta e se utilizou de alguns dos materiais e procedimentos laboratoriais.

A associação entre as pesquisas permitiu a utilização dos resultados de caracterização de materiais e de dosagens das misturas, assim como alguns dos resultados de ensaios de propriedades mecânicas originais. Ao todo foram moldados 72 corpos-de-prova que alternaram os fatores (i) tipo de asfalto, (ii) presença de aditivo e (iii) modo de preparo da mistura. Desse total, esta pesquisa consumiu 48 dos corpos-de-prova para as análises que se apresentam, excluindo os corpos de prova utilizados nas diversas dosagens.

Seguindo as recomendações de Furlan (2006), a execução dos ensaios de propriedades mecânicas dos CPs de controle e condicionados foram realizados em um intervalo de tempo máximo de três dias, para evitar algum efeito não controlado devido ao tempo de armazenamento.

Paralelamente, durante a execução dos ensaios não destrutivos, foi desenvolvido um estudo sobre a suscetibilidade térmica das misturas asfálticas, onde os CPs desta pesquisa passaram por uma série de ensaios de módulo de resiliência (MR) em três diferentes temperaturas. Com esse projeto foi possível levantar as curvas de rigidez versus temperatura das misturas asfálticas e compreender a suscetibilidade térmica das diversas misturas asfálticas testadas.

\subsubsection{Teor de asfalto de projeto (TP)}

Para a determinação do teor de asfalto de projeto da mistura, foram obedecidas as recomendações Superpave ${ }^{\circledR}$. Para a definição dos teores de asfalto a serem testados na dosagem das misturas asfálticas foi utilizado o método da superfície específica, que permitiu uma primeira previsão do consumo de asfalto necessário para o recobrimento dos agregados, ou teor inicial (ti). Foram moldados corpos-de-prova em três outros teores de asfalto além do teor inicial (ti-0,5\%, ti+0,5\% e ti+1\%). A compactação dos CPs foi realizada num Compactador Giratório Superpave (CGS), para valores de pressão aplicada de $600 \mathrm{kPa}$, ângulo de rotação de $1,25^{\circ}$ e uma velocidade de 30 RPM. 
A compactação dos corpos de prova foi efetuada após o procedimento de estabilização da temperatura das misturas asfálticas, que consistiu da permanência em estufa, da massa não compactada, na temperatura de compactação. Segundo a AASHTO PP2 esse procedimento poderia ainda permitir alguma absorção de ligante asfáltico pelo agregado.

Como a compactação foi feita num compactador giratório, foram seguidas parcialmente as instruções do Método de Dosagem Superpave ${ }^{\circledR}$, como o tipo de tráfego, número de giros e critérios volumétricos. Assim sendo, as misturas asfálticas foram dosadas considerando o tráfego médio a alto, o número de 160 giros $\left(\mathrm{N}_{\text {máximo }}\right)$ para a finalização da compactação dos CPs e o número de 100 giros $\left(\mathrm{N}_{\text {projeto }}\right)$ para se atingir o $\mathrm{Vv}$ de $4 \%$, vazios do agregado mineral (VAM) superior a $11 \%$ e relação betume vazios (RBV) entre $65 \%$ e $75 \%$.

Outros parâmetros de controle relacionados aos valores de massa específica também foram testados. De acordo com a Dosagem Superpave ${ }^{\circledR}$, para o tráfego de médio a alto, a massa específica máxima $(\mathrm{Gmm})$ deve ser maior ou igual a $89 \%$ no $\mathrm{N}_{\text {inicial }}$ (8 giros), para garantir a estrutura do esqueleto mineral; e menor ou igual a $98 \%$ no $\mathrm{N}_{\text {máximo }}(160$ giros), para evitar compactação excessiva.

Para todas as dosagens efetuadas, foram preparados 3 CPs por teor de asfalto, sendo 2 CPs para a dosagem propriamente e $1 \mathrm{CP}$ para a determinação da densidade máxima teórica (DMT) a partir do ensaio de Rice (ASTM D 2041).

As dosagens das misturas produzidas com os dois tipos de asfalto (CAP 50/70 e CAP 50/70+SBS) resultaram nas curvas de volume de vazios versus teor de asfalto apresentadas na figura 3.3. Uma das exigências do Superpave ${ }^{\circledR}$ é que a quantidade de asfalto usada deve ser tal que a mistura atinja 4\% de vazios no número de giros do projeto (100 giros). De posse dos resultados de dosagem apresentados na figura 3.3, ao se verificar na curva o valor de $4 \%$ de volume de vazios tem-se o teor de 4,3\%, para o CAP 50/70, e 4,5\%, para o CAP 50/70+SBS. 

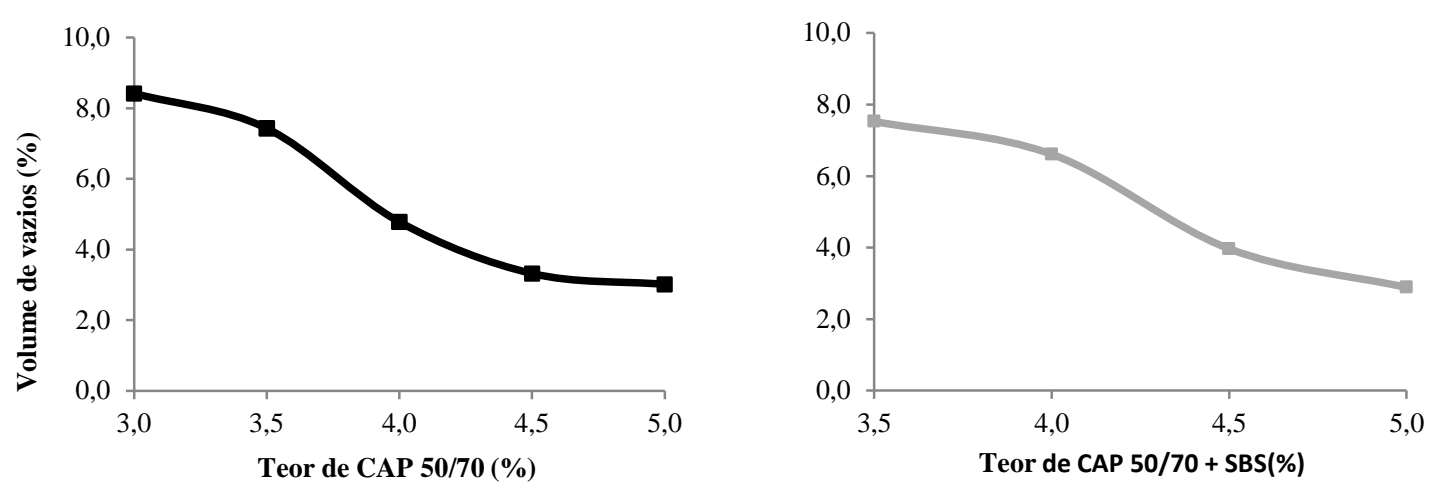

FIGURA 3.3: Volume de vazios versus teor de asfalto

A Tabela 3.5 apresenta um resumo das características volumétricas (em termos médios) das dosagens das misturas para os dois diferentes tipos de asfalto, nela se observa que os valores dos parâmetros de controle foram obedecidos, como: $\mathrm{Vv}$ de $4 \%$, VAM $\geq 11 \%$ e $65 \% \leq \mathrm{RBV} \leq 75 \%$. Há que se antecipar uma preocupação deste autor com relação aos $\mathrm{TP}$ encontrados, que, ainda que os parâmetros de controle tenham obedecido às recomendações do Superpave ${ }^{\circledR}$, foram valores muito baixos.

TABELA 3.5: Propriedades volumétricas das misturas dosadas

\begin{tabular}{ccc}
\hline & CAP 50/70 & CAP 50/70+SBS \\
\hline TP(\%) & 4,3 & 4,5 \\
Vv (\%) & 4,0 & 4,0 \\
$\mathbf{G m b}\left(\mathbf{g} / \mathbf{c m}^{3}\right)$ & 2,361 & 2,359 \\
DMT $\left(\mathbf{g} / \mathbf{c m}^{3}\right)$ & 2,465 & 2,475 \\
VAM (\%) & 13,5 & 14,4 \\
RBV $(\%)$ & 74,2 & 72,9 \\
\hline
\end{tabular}

\subsubsection{Absorção de asfalto pelo agregado}

Nesta pesquisa foram utilizados dois métodos de ensaio para a determinação do dano por umidade de misturas asfálticas. A principal diferença entre os procedimentos está na simulação dos envelhecimentos em curto (ASTM D 4867) e em longo prazo (AASHTO T 283), que é procedido a partir de diferentes modos de preparo das misturas asfálticas. 
O procedimento de envelhecimento em curto prazo da ASTM D 4867 preconiza que, antes da compactação dos corpos-de-prova, a mistura asfáltica seja mantida em estufa durante 2 horas na temperatura de compactação. Já no método da AASHTO T 283, a mistura não compactada é mantida numa estufa ventilada a $60{ }^{\circ} \mathrm{C}$ por 16 horas, e, a seguir, permanece por duas horas em estufa na temperatura de compactação.

Esses procedimentos de simulação envolvem variadas temperaturas combinadas a períodos relativamente longos, provocando com isso o enrijecimento do asfalto por efeito de algum envelhecimento ou de alguma absorção de asfalto pelo agregado. Por isso, procedeu-se uma avaliação da absorção de asfalto pelos agregados, com o intuito de entender o efeito dos procedimentos de envelhecimento (ASTM e AASHTO) na absorção de asfalto.

A determinação da taxa de absorção de asfalto pelo agregado foi obtida a partir da relação entre as densidades efetiva e aparente do agregado, como mostra a Equação 3.1. A densidade efetiva foi calculada a partir da Equação 3.2, sendo que o valor de DMT foi obtido do ensaio Rice.

$$
\begin{gathered}
A b s_{a s f}=\frac{\rho_{e f}-\rho_{a p}}{\rho_{e f} \times \rho_{a p}} \times \rho_{b} \times 100 \\
\rho_{e f}=\frac{1-P b}{\frac{1}{D M T}-\frac{P b}{\rho_{b}}}
\end{gathered}
$$

Onde:

$\rho_{\text {ef }}$ é a densidade efetiva do agregado, $\rho_{\mathrm{ap}}$ é a densidade aparente do agregado,

DMT é a densidade máxima teórica, $\mathrm{Pb}$ é o teor de asfalto, $\rho_{\mathrm{b}}$ é a densidade do asfalto. 


\subsection{PROPRIEDADES MECÂNICAS DAS MISTURAS ASFÁLTICAS}

\subsubsection{Módulo de Resiliência}

Para avaliação da suscetibilidade térmica das misturas asfálticas foram realizados ensaios para obtenção do módulo de resiliência em diferentes temperaturas. O procedimento consistiu da aplicação de 100 ciclos de carregamento de magnitude fixa, com 1,0 segundo de duração, sendo cada ciclo constituído por um período de carregamento de 0,1 segundo e um período de repouso de 0,9 segundo.

Para uma maior confiabilidade dos dados, os primeiros 30 ciclos foram descartados, sendo assim, os 70 últimos valores foram os ciclos que serviram para o cálculo de MR, com esse procedimento conseguiu-se um desvio padrão dos valores inferior a $5 \%$.

Os ensaios de módulo de resiliência foram executados em todos os corpos-de-prova, e em alguns casos mais de uma vez. Os ensaios foram considerados válidos quando um valor de deformação inicial fosse atingido, adotou-se o intervalo de deformações iniciais entre 0,0018 a $0,0023 \mathrm{~mm}$, sendo às vezes necessário ajustar a carga para que os valores ficassem neste intervalo.

Além disso, como se tratou de um estudo da suscetibilidade térmica, foi adotada uma ordem de procedimento dos ensaios nas diferentes temperaturas, a saber: 10, 25 e $40^{\circ} \mathrm{C}$. Esse cuidado foi tomado para evitar alguma deterioração decorrente das deformações que os CPs pudessem apresentar.

Os CPs foram colocados numa câmara climatizada e permaneceram por, no mínimo, 24 horas para estabilização da temperatura dos corpos-de-prova. Para auxiliar a manutenção da temperatura dos corpos-de-prova no ensaio, foi utilizada uma estufa climatizada com regulagem de temperatura.

O valor do MR foi calculado de acordo com a norma da AASHTO TP 31, e é expresso por: 


$$
M R=\frac{F}{\Delta h}(0,9976 \mu+0,2692)
$$

Onde:

MR é o módulo de resiliência, em MPa;

F é a carga vertical repetida aplicada diametralmente ao corpo-de-prova, em N;

$\Delta$ é o deslocamento total, em $\mathrm{mm}$;

H é a altura do corpo-de-prova, em mm;

$\mu$ e o coeficiente de Poisson $(0,30)$.

Foram calculados também dois parâmetros incidentais do ensaio de MR, que são: a recuperação retardada e o atraso. Furlan (2006) conceitua a recuperação retardada (RR) como a recuperação que ocorre no período de descarregamento, este parâmetro está indiretamente relacionado com a viscoelasticidade do material; com ele se pode detectar alterações de comportamento das misturas asfálticas quanto à forma de resposta resiliente e, inclusive, observar se um aumento de valor de MR implica em misturas asfálticas mais elásticas ou mais viscosas. O parâmetro é obtido a partir das expressões:

$$
\begin{array}{r}
R R=\left(\frac{M R_{I}-M R_{T}}{M R_{I}}\right) \times 100 \\
R R=\frac{\left(\frac{\sigma}{\varepsilon_{I}}-\frac{\sigma}{\varepsilon_{T}}\right)}{\left(\frac{\sigma}{\varepsilon_{I}}\right)}=\frac{\varepsilon_{T-} \varepsilon_{I}}{\varepsilon_{T}} \times 100
\end{array}
$$

Onde:

RR é a recuperação retardada, em \%;

$\mathrm{MR}_{\mathrm{I}}$ é o módulo instantâneo, em MPa;

$\mathrm{MR}_{\mathrm{T}}$ é o módulo total, em MPa;

$\sigma$ é a tensão aplicada;

$\varepsilon_{\mathrm{T}}$ é a deformação total;

$\varepsilon_{I}$ é a deformação elástica instantânea. 
Outro parâmetro de rigidez determinado a partir dos ensaios de módulo de resiliência é o atraso e é expresso em segundos. O atraso é uma medida de defasagem entre os picos dos pulsos de carga e de deslocamento. Esse parâmetro também tem relação com a viscoelasticidade do material, mas nesse caso a resposta é avaliada no período de carregamento (FURLAN, 2006).

\subsubsection{Resistência à tração por compressão diametral}

Os ensaios de resistência à tração foram realizados a $25^{\circ} \mathrm{C}$ e em conformidade com a norma DNER ME 138/94. Com a média da resistência a tração do grupo condicionado e do de controle em mãos, verificou-se então a relação de resistência à tração (RRT). A resistência à tração foi determinada a partir da seguinte expressão:

$$
\sigma_{R}=\frac{2 F}{\pi d h}
$$

Onde:

$\sigma_{\mathrm{R}}$ é a resistência a tração, em $\mathrm{MPa}$;

F é a carga de ruptura, em N;

d é o diâmetro médio do corpo-de-prova, em mm.

\subsubsection{Ensaios de avaliação da suscetibilidade ao dano por umidade}

Os métodos empregados para a avaliação da suscetibilidade ao dano por umidade das misturas asfálticas são os ensaios normalizados pela ASTM e pela AASHTO, que avaliam a tendência da sensibilidade à ação da água em curto e em longo prazos, respectivamente. Esses métodos avaliam o dano por umidade de misturas asfálticas compactadas a partir da redução de uma propriedade mecânica, quando um CP é submetido à saturação parcial e a algum ciclo térmico, cuja função é descolar a película de asfalto do agregado provocada pelos efeitos do 
tráfego ou da ação de temperaturas diferenciais de congelamento e descongelamento dos materiais.

Ambas as normas preconizam que a mistura asfáltica seja compactada para resultar no volume de vazios de $7 \%$ ou o de campo. Após a produção dos CPs e levantadas as características volumétricas, eles são divididos em dois grupos, sendo um grupo, o de referência ou de controle, e outro, o condicionado, porque deve ser submetido à saturação parcial e condicionamento térmico.

O condicionamento térmico da ASTM D 4867 consiste da imersão dos CPs, parcialmente saturados, em banho a $60^{\circ} \mathrm{C}$ por um período de $24 \mathrm{~h}$. Já o condicionamento térmico da AASHTO T 283, o CP parcialmente saturado é embalado em filme plástico e colocado em um saco plástico com $10 \mathrm{ml}$ de água destilada e é levado a um ciclo de congelamento onde é exposto a uma temperatura de $-18^{\circ} \mathrm{C}$ por 16 horas. Em seguida, os CPs são submetidos a um banho a $60^{\circ} \mathrm{C}$ por 24 horas.

Após o condicionamento térmico os CPs tem sua temperatura estabilizada em $25^{\circ} \mathrm{C}$ e levados à ruptura no ensaio de tração por compressão diametral. A relação de resistência à tração é obtida pela razão entre a média da RT do grupo condicionado e a do grupo de controle. $\mathrm{O}$ valor de RRT é um indicador da suscetibilidade da mistura ao dano por umidade, assim, para a ASTM, esse valor é de $70 \%$ e para a AASHTO é de $80 \%$.

Conforme recomendam os métodos da ASTM D4867 e AASTHO T283, os relatórios dos ensaios devem também conter apontamentos das características das superfícies de ruptura dos CPS, observando-se se houve descolamento, quebra de agregados ou alguma particularidade.

A Tabela 2 apresenta um resumo dos procedimentos dos ensaios, onde se observa melhor as suas particularidades. Para manter condições experimentais similares entre os métodos foi adotado o mesmo intervalo do grau de saturação (70 a 80\%) e o mesmo ciclo térmico de condicionamento, composto de uma fase de congelamento $\left(-18^{\circ} \mathrm{C}\right.$ durante $\left.16 \mathrm{~h}\right)$ e outra de descongelamento $\left(60^{\circ} \mathrm{C}\right.$ durante $\left.24 \mathrm{~h}\right)$, seguido da execução do ensaio resistência à tração por compressão diametral. 
TABELA 3.6: Principais procedimentos da ASTM D 4867 e da AASHTO T 283

\begin{tabular}{|c|c|c|c|c|c|c|}
\hline Norma & $\begin{array}{l}\mathrm{Vv} \\
(\%)\end{array}$ & Envelhecimento & Saturação & \multicolumn{2}{|c|}{ Ciclo térmico } & RRT \\
\hline $\begin{array}{l}\text { ASTM } \\
(1999)\end{array}$ & $6-8 \%$ & Não há & $\begin{array}{c}\text { Vácuo: } \\
500 \text { mmHg } \\
\text { por } 5 \text { minutos } \\
\text { Saturação: } \\
55-80 \%\end{array}$ & $\begin{array}{c}-18^{\circ} \mathrm{C} \text { por } 16 \\
\text { horas }\end{array}$ & $\begin{array}{c}\text { Aquecimento } \\
60^{\circ} \mathrm{C} \text { por } 24 \\
\text { horas }\end{array}$ & $70 \%$ \\
\hline $\begin{array}{l}\text { AASHTO } \\
(2003)\end{array}$ & $6-8 \%$ & $\begin{array}{l}\text { Mistura não } \\
\text { compactada } 60^{\circ} \mathrm{C} \\
\text { por } 16 \text { horas }\end{array}$ & $\begin{array}{c}\text { Vácuo: } \\
500 \mathrm{mmHg} \\
\text { por } 5 \text { minutos } \\
\text { Saturação: } \\
70-80 \%\end{array}$ & $\begin{array}{c}-18^{\circ} \mathrm{C} \text { por } 16 \\
\text { horas }\end{array}$ & $\begin{array}{c}60^{\circ} \mathrm{C} \text { por } 24 \\
\text { horas }\end{array}$ & $80 \%$ \\
\hline
\end{tabular}

\subsubsection{Tratamento dos dados}

Os resultados dos ensaios efetuados nesta pesquisa foram avaliados a partir da interpretação de gráficos de comportamento para o entendimento do efeito isolado das variáveis. Em seguida os resultados foram analisados a partir da técnica da Análise de Variância (ANOVA) com auxílio do programa computacional Minitab versão 14, com isso foi possível não somente ratificar os resultados da análise dos efeitos isolados, mas entender a importância da interação dos efeitos, assim como modelar propriedades a partir das variáveis. 


\section{APRESENTAÇÃO E ANÁLISE DOS RESULTADOS}

\subsection{INTRODUÇÃO}

Neste capítulo são apresentados e analisados os resultados dos ensaios para a avaliação da suscetibilidade térmica e ao dano por umidade. Para tanto, foi observada a tendência de comportamento do efeito dos fatores selecionados para o programa experimental. A avaliação da suscetibilidade térmica foi feita com base na observação da variação dos valores de MR e dos parâmetros de rigidez em função do aumento da temperatura; e a análise da suscetibilidade ao dano por umidade baseou-se nos valores de RRT. Foi também elaborado um estudo sobre os efeitos das variáveis do programa experimental sobre a absorção de asfalto pelo agregado.

Os resultados foram avaliados em termos médios, considerando $3 \mathrm{CPs}$, buscando destacar o efeito isolado da variável em determinada propriedade. Esses resultados foram analisados estatisticamente, a partir da ANOVA, com o intuito de observar também os efeitos de interação dos fatores nas propriedades mecânicas e de durabilidade, além de ratificar as análises de tendências de comportamento.

A apresentação dos resultados e suas análises foram efetuadas considerando inicialmente a apreciação das propriedades originais das misturas asfálticas, como forma de caracterizá-las em termos de rigidez e resistência; em seguida, foi analisada a capacidade de retenção da propriedade das misturas asfálticas. 


\subsection{Avaliação das propriedades originais}

\subsubsection{Propriedades volumétricas}

Para a execução dos ensaios de propriedades mecânicas (originais) e de durabilidade (dano por umidade) foram moldados seis CPs por condição experimental, reproduzindo as condições de teor de asfalto de projeto (TP) obtidas da dosagem. Vale destacar que foram realizadas dosagens das misturas com o asfalto convencional e com o asfalto modificado e os TPs foram mantidos mesmo quando da adição de cal e das mudanças nos modos de preparo (ASTM e AASHTO). A Tabela 4.1 apresenta algumas das principais características volumétricas dos diferentes grupos de misturas asfálticas, nela se pode notar que os CPs foram compactados para encontrarem volume de vazios entre 6 e $8 \%$, como recomendado, para a execução dos ensaios de dano por umidade das duas normas testadas.

TABELA 4.1: Características volumétricas das misturas asfálticas

\begin{tabular}{|c|c|c|c|c|c|c|c|}
\hline Tipos de & nisturas & Tipo de asfalto & $\begin{array}{c}\text { Gmb } \\
\left(\mathrm{g} / \mathrm{cm}^{3}\right)\end{array}$ & $\begin{array}{c}\mathbf{G m m} \\
\left(\mathrm{g} / \mathrm{cm}^{3}\right)\end{array}$ & $\begin{array}{l}\text { Vv } \\
(\%)\end{array}$ & $\begin{array}{c}\text { VAM } \\
(\%)\end{array}$ & $\begin{array}{r}\text { RBV } \\
(\%) \\
\end{array}$ \\
\hline \multirow{4}{*}{ ASTM } & \multirow{2}{*}{ Sem cal } & 4,3\% CAP 50/70 & 2,273 & 2,441 & 6,9 & 16,4 & 57 \\
\hline & & 4,5\% CAP 50/70+ SBS & 2,267 & 2,437 & 6,7 & 17,1 & 72 \\
\hline & \multirow{2}{*}{ Com cal } & 4,3\% CAP 50/70 & 2,274 & 2,434 & 6,9 & 16,1 & 54 \\
\hline & & $4,5 \%$ CAP 50/70+ SBS & 2,273 & 2,434 & 6,6 & 16,7 & 69 \\
\hline \multirow{4}{*}{ AASHTO } & \multirow{2}{*}{ Sem cal } & 4,3\% CAP 50/70 & 2,291 & 2,465 & 8,3 & 16,7 & 60 \\
\hline & & $4,5 \%$ CAP 50/70+ SBS & 2,295 & 2,475 & 8,3 & 17,5 & 78 \\
\hline & \multirow{2}{*}{ Com cal } & 4,3\% CAP 50/70 & 2,293 & 2,466 & 7,8 & 16,6 & 60 \\
\hline & & 4,5\% CAP 50/70+ SBS & 2,290 & 2,458 & 6,7 & 17,0 & 73 \\
\hline
\end{tabular}

O fato dos modos de preparo das misturas asfálticas dos métodos de avaliação de suscetibilidade ao dano por umidade serem diferentes podem resultar em diferentes taxas de absorção de asfalto. Além disso, poderia ser questionado se a absorção de asfalto pelo agregado pode ser vantajosa no que se refere à resistência ao dano por umidade, por isso, foi feita uma apreciação das taxas de absorção das misturas asfálticas produzidas (ASTM e AASHTO). A tabela 4.2 mostra um resumo dos resultados de absorção de asfalto obtidos para as diferentes misturas produzidas. As taxas de absorção foram calculadas considerando a densidade do asfalto de $1,02 \mathrm{~g} / \mathrm{cm}^{3}$ e a densidade máxima teórica de 2,593 g/ $\mathrm{cm}^{3}$. 
TABELA 4.2: Absorção de asfalto pelo agregado

\begin{tabular}{|c|c|c|c|c|c|}
\hline \multicolumn{2}{|c|}{ Tipos de misturas } & Tipo de asfalto & $\begin{array}{r}\text { DMT } \\
\left(\mathrm{g} / \mathrm{cm}^{3}\right)\end{array}$ & $\begin{array}{c}\rho_{\text {efetiva }} \\
\left(\mathrm{g} / \mathbf{c m}^{3}\right)\end{array}$ & $\begin{array}{c}\text { Asfalto absorvido } \\
(\%)\end{array}$ \\
\hline \multirow{4}{*}{ ASTM } & \multirow{2}{*}{ Sem cal } & 4,3\% CAP 50/70 & 2,441 & 2,602 & 0,22 \\
\hline & & $4,5 \%$ CAP 50/70+ SBS & 2,437 & 2,608 & 0,31 \\
\hline & \multirow{2}{*}{ Com cal } & 4,3\% CAP 50/70 & 2,434 & 2,594 & 0,09 \\
\hline & & 4,5\% CAP 50/70+ SBS & 2,434 & 2,604 & 0,25 \\
\hline \multirow{4}{*}{ AASHTO } & \multirow{2}{*}{ Sem cal } & $4,3 \%$ CAP 50/70 & 2,469 & 2,635 & 0,71 \\
\hline & & $4,5 \%$ CAP 50/70+ SBS & 2,472 & 2,650 & 0,93 \\
\hline & \multirow{2}{*}{ Com cal } & 4,3\% CAP 50/70 & 2,467 & 2,633 & 0,68 \\
\hline & & 4,5\% CAP 50/70+ SBS & 2,456 & 2,631 & 0,65 \\
\hline
\end{tabular}

Observando-se os resultados de absorção, pode-se concluir que o modo de preparo foi o fator com efeito mais intenso na taxa de absorção das misturas, e que as misturas AASHTO apresentaram taxas de absorção cerca de 3 vezes maiores que as misturas ASTM, com destaque para a mistura com CAP50/70 e cal que apresentou valor de absorção 7,5 vezes maior quando produzida a partir do método da AASHTO. Esse comportamento pode ser decorrente da combinação do procedimento de envelhecimento em longo prazo $\left(60^{\circ} \mathrm{C}\right.$ por 16h) combinado ao de estabilização de temperatura de compactação (temperatura de compactação por $2 \mathrm{~h})$.

A figura 4.1 apresenta um gráfico com os valores das taxas de absorção das diferentes misturas, nela se pode observar que as misturas CAP 50/70+SBS obtiveram as maiores taxas para ambos os modos de preparo. Uma hipótese para explicar essa constatação pode ser as altas temperaturas de usinagem e compactação das misturas com o asfalto modificado quando comparadas às temperaturas das misturas com o asfalto convencional. Isso porque, por vezes, foi necessário trabalhar no limite superior do intervalo de temperatura da operação e isso pode ter reduzido a viscosidade do asfalto modificado e facilitado sua absorção pelo agregado.

Quanto ao efeito da cal na absorção de asfalto, observa-se que, de forma geral, a cal reduziu a taxa de absorção, mas esse efeito foi mais evidente nas misturas ASTM com CAP 50/70 e AASHTO com CAP+SBS. A intensidade do efeito da cal foi a menor entre os fatores testados. 


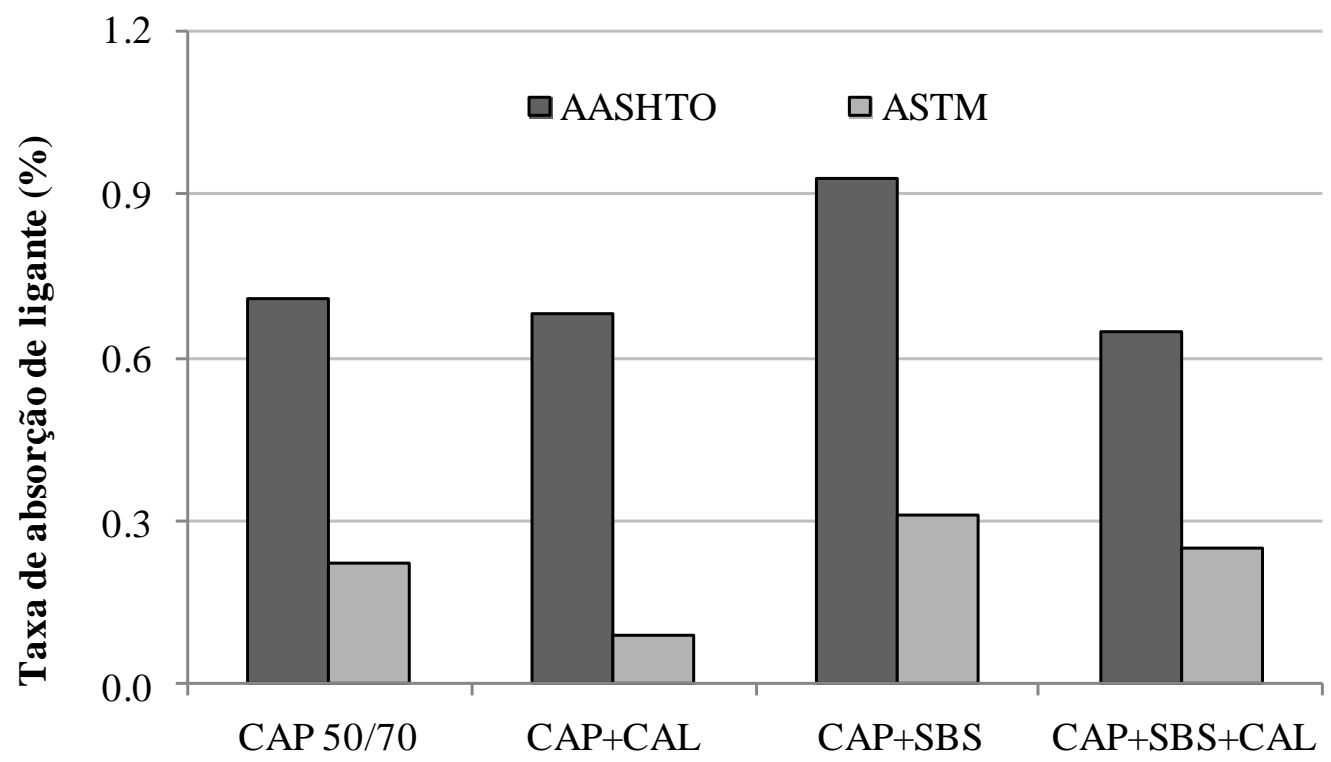

FIGURA 4.1: Absorção de asfalto pelo agregado

A Tabela 4.2 e a figura 4.1 permitem concluir que sempre houve alguma absorção de asfalto pelo agregado, ainda que em taxas relativamente baixas e que, de modo geral:

a) a simulação de envelhecimento em longo prazo do método da AASHTO levou às maiores taxas de absorção de asfalto pelo agregado, independente do tipo de asfalto e da presença ou não de cal nas misturas testadas; sendo este aumento da ordem de $300 \%$;

b) as misturas com asfalto modificado (CAP 50/70+SBS) apresentaram maiores taxas de absorção de asfalto que as misturas com asfalto convencional (CAP 50/70), sendo esse aumento de cerca de $40 \%$, e;

c) a cal atuou reduzindo as taxas de absorção de asfalto pelo agregado, tendo sido seu efeito o de menor intensidade, da ordem de $20 \%$.

\subsubsection{Propriedades mecânicas originais}

Para a caracterização das propriedades mecânicas originais (antes do condicionamento térmico) das misturas asfálticas, foram realizados ensaios de módulo de resiliência (MR) e resistência à tração (RT). Na tabela 4.3 são apresentados os resultados dos $\mathrm{MR}$ e $\mathrm{RT}$ a $25^{\circ} \mathrm{C}$ 
das misturas produzidas. Os valores das propriedades são apresentados em termos médios, para grupos de 3 corpos-de-prova, e apresentaram valores de desvio no grupo inferiores a $15 \%$.

A partir dos resultados da Tabela 4.3, pode-se notar que, de modo geral, foi observado que os valores de MR e RT sofreram pequena influencia da variação dos fatores experimentais. Considerando todas as condições experimentais, os valores do coeficiente de variação (razão do desvio padrão e a média) foram da ordem de $10 \%$ para MR e RT .

TABELA 4.3: MR e RT das misturas testadas $\left(25^{\circ} \mathrm{C}\right)$

\begin{tabular}{lcccc}
\hline & \multicolumn{2}{c}{ ASTM } & \multicolumn{2}{c}{ AASHTO } \\
\hline \multicolumn{1}{c}{ Propriedades } & MR & RT & MR & RT \\
Misturas com & $($ MPa $)$ & $(\mathbf{M P a})$ & $(\mathbf{M P a})$ & $(\mathbf{M P a})$ \\
\hline CAP 50/70 & 5331 & 1,41 & 4767 & 1,30 \\
CAP 50/70+Cal & 4923 & 1,40 & 6389 & 1,49 \\
CAP 50/70+SBS & 5287 & 1,73 & 5576 & 1,58 \\
CAP 50/70+SBS+Cal & 5675 & 1,62 & 5929 & 1,76 \\
\hline
\end{tabular}

A figura 4.2 apresenta os resultados de MR e RT de todas as misturas testadas, nela se pode visualizar algumas tendências de comportamentos. No que se refere aos efeitos e à intensidade dos efeitos das variáveis, pode se notar que as simulações de envelhecimento dos métodos ASTM e AASHTO, por exemplo, levaram a variações de valores de MR, em média, de $16 \%$, sendo que as misturas AASHTO apresentaram MR maiores, exceto para a mistura com CAP 50/70. No caso da RT, as variações foram, da ordem, de $10 \%$, sendo que as misturas com CAP 50/70 apresentaram redução de RT com o envelhecimento ASTM e as com CAP 50/70+SBS apresentaram aumento de RT. 

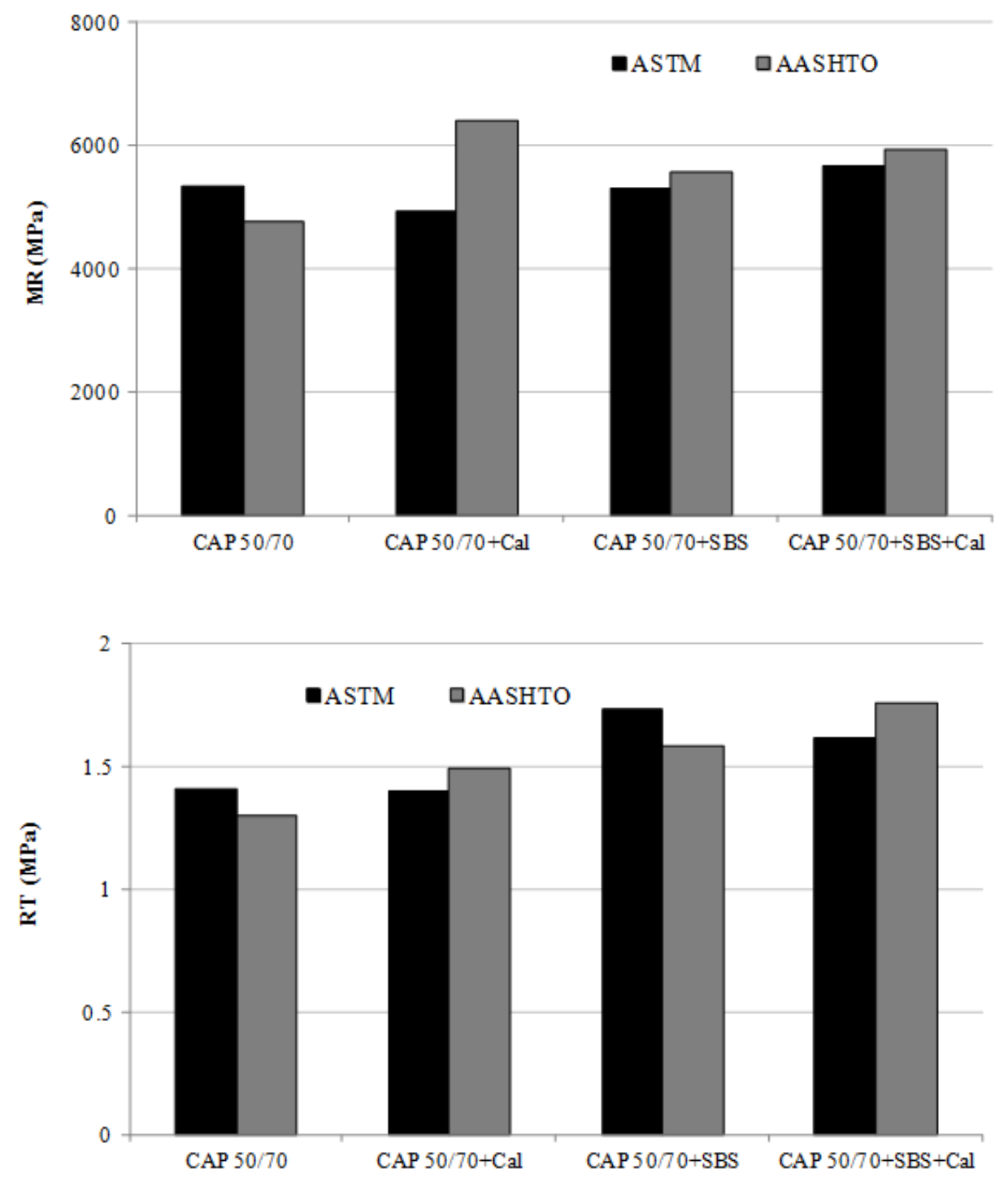

FIGURA 4.2: MR e RT das misturas testadas

Quanto ao efeito da mudança do tipo de asfalto, notou-se que as misturas com CAP 50/70+SBS apresentaram, de modo geral, maiores valores de MR e RT, com exceção da mistura com CAP50/70+cal. Já quanto à adição de cal, pode-se dizer que MR e RT exibiram tendência de aumento com a adição da cal exceto as misturas com CAP 50/70.

\subsubsection{Suscetibilidade térmica das misturas asfálticas}

A suscetibilidade térmica das misturas asfálticas foi estudada a partir dos resultados de ensaios de MR em três temperaturas: 10,25 e $40^{\circ} \mathrm{C}$. No anexo I, estão apresentados os 
valores de MR de todos os CPs testados. Para análise apresentada a seguir, é feita uma apreciação do valor médio de MR das tréplicas de cada condição experimental.

As tabelas 4.4 e 4.5 apresentam os resultados de MR, RR e atraso das misturas produzidas a partir do método da ASTM (que tem como característica o envelhecimento em curto prazo), e do método da AASHTO (que tem como característica o envelhecimento em longo prazo), respectivamente.

TABELA 4.4: Rigidez e parâmetros de rigidez das misturas produzidas a partir da ASTM

\begin{tabular}{|c|c|c|c|c|c|c|c|c|c|}
\hline Temperatura $\left({ }^{\circ} \mathrm{C}\right)$ & & 10 & & & 25 & & & 40 & \\
\hline $\begin{array}{l}\text { Propriedades } \\
\text { Misturas com }\end{array}$ & $\begin{array}{c}\text { MR } \\
\text { (MPa) }\end{array}$ & $\begin{array}{l}\text { RR } \\
(\%)\end{array}$ & $\begin{array}{l}\text { Atraso } \\
\left(10^{-2} s\right)\end{array}$ & $\begin{array}{c}\text { MR } \\
\text { (MPa) }\end{array}$ & $\begin{array}{l}\text { RR } \\
(\%)\end{array}$ & $\begin{array}{l}\text { Atraso } \\
\left(10^{-2} s\right)\end{array}$ & $\begin{array}{c}\text { MR } \\
\text { (MPa) }\end{array}$ & $\begin{array}{l}\text { RR } \\
(\%)\end{array}$ & $\begin{array}{l}\text { Atraso } \\
\left(10^{-2} s\right)\end{array}$ \\
\hline CAP 50/70 & 14845 & 20 & 4,1 & 5331 & 28 & 4,6 & 2005 & 15 & 5,1 \\
\hline CAP 50/70+Cal & 14709 & 19 & 4,1 & 4923 & 28 & 4,5 & 2124 & 28 & 5,1 \\
\hline CAP 50/70+SBS & 12468 & 18 & 4,1 & 5287 & 25 & 4,5 & 2012 & 29 & 4,9 \\
\hline CAP 50/70+SBS+Cal & 11655 & 20 & 4,2 & 5675 & 28 & 4,5 & 1960 & 29 & 5,0 \\
\hline
\end{tabular}

TABELA 4.5: Rigidez e parâmetros de rigidez das misturas produzidas a partir da AASHTO

\begin{tabular}{|c|c|c|c|c|c|c|c|c|c|}
\hline Temperatura & & 10 & & & 25 & & & 40 & \\
\hline $\begin{array}{l}\text { Propriedades } \\
\text { Misturas com }\end{array}$ & $\begin{array}{c}\text { MR } \\
(\mathrm{MPa})\end{array}$ & $\begin{array}{l}\text { RR } \\
(\%)\end{array}$ & $\begin{array}{l}\text { Atraso } \\
\left(10^{-2} s\right)\end{array}$ & $\begin{array}{c}\text { MR } \\
(\mathrm{MPa})\end{array}$ & $\begin{array}{l}\text { RR } \\
(\%)\end{array}$ & $\begin{array}{l}\text { Atraso } \\
\left(10^{-2} s\right)\end{array}$ & $\begin{array}{c}\text { MR } \\
\text { (MPa) }\end{array}$ & $\begin{array}{l}\text { RR } \\
(\%)\end{array}$ & $\begin{array}{l}\text { Atraso } \\
\left(10^{-2} s\right)\end{array}$ \\
\hline CAP 50/70 & 12618 & 24 & 4,1 & 4767 & 31 & 4,6 & 1065 & 25 & 5,0 \\
\hline CAP 50/70+Cal & 14209 & 21 & 4,1 & 6389 & 30 & 4,6 & 1745 & 28 & 5,0 \\
\hline CAP 50/70+SBS & 10230 & 24 & 4,2 & 5576 & 28 & 4,5 & 1540 & 23 & 4,9 \\
\hline CAP 50/70+SBS+Cal & 9751 & 24 & 4,0 & 5929 & 27 & 4,5 & 2327 & 26 & 4,9 \\
\hline
\end{tabular}

De modo geral, ambos os tipos de misturas (ASTM e AASHTO) sofreram grande influência da variação de temperatura, tendo uma redução de MR muito importante com o aumento da temperatura. No que se refere aos parâmetros de rigidez (RR e atraso), ainda que tenham exibido variações de valores com o aumento da temperatura, a intensidade do efeito não se mostrou tão importante quanto no MR.

Observando-se os valores das Tabelas 4.4 e 4.5, pode se dizer que a variação da temperatura de 10 para $25^{\circ} \mathrm{C}$ reduziu o MR em cerca de $60 \%$ para as misturas ASTM, e em $50 \%$ para as 
misturas AASHTO. Já para a variação de temperatura de 25 para $40^{\circ} \mathrm{C}$, a redução média de MR das misturas ASTM foi de 60\%, e das misturas AASHTO foi de $70 \%$.

Considerando variação de temperatura de 10 para $40^{\circ} \mathrm{C}$, observa-se que ambos os tipos de misturas (ASTM e AASHTO) apresentaram reduções de MR da mesma ordem, em média, de 85\%. É importante identificar o comportamento em intervalos de temperatura (por ex.: 10$25^{\circ} \mathrm{C}$ e $25-40^{\circ} \mathrm{C}$ ) para observar se há alguma peculiaridade do material que o torna mais adequado em determinadas faixas de temperaturas.

Com relação aos parâmetros de rigidez, observou-se que o aumento da temperatura, aumentou em 20\%, aproximadamente, os valores de RR e atraso das misturas ASTM e AASHTO. Quando esses parâmetros são observados considerando os intervalos de temperatura de 10 a $25^{\circ} \mathrm{C}$ e de 25 a $40^{\circ} \mathrm{C}$, observou-se que, de maneira geral, o comportamento de RR tende a se estabilizar com o aumento da temperatura e que o atraso exibiu variações de mesma ordem.

A figura 4.3 apresenta o comportamento de MR versus temperatura. Para efeito de comparação entre os dois métodos de produção da mistura, os resultados são apresentados em dois gráficos, AASHTO e ASTM. Nota-se que em ambos os métodos, a mistura asfáltica com CAP 50/70 sofreu uma queda maior quando do aumento da temperatura de 10 para $25^{\circ} \mathrm{C}$, enquanto que para o CAP 50/70+SBS essa variação foi mais constante ao longo do intervalo geral $\left(10^{\circ} \mathrm{C}\right.$ a $\left.40^{\circ} \mathrm{C}\right)$. 

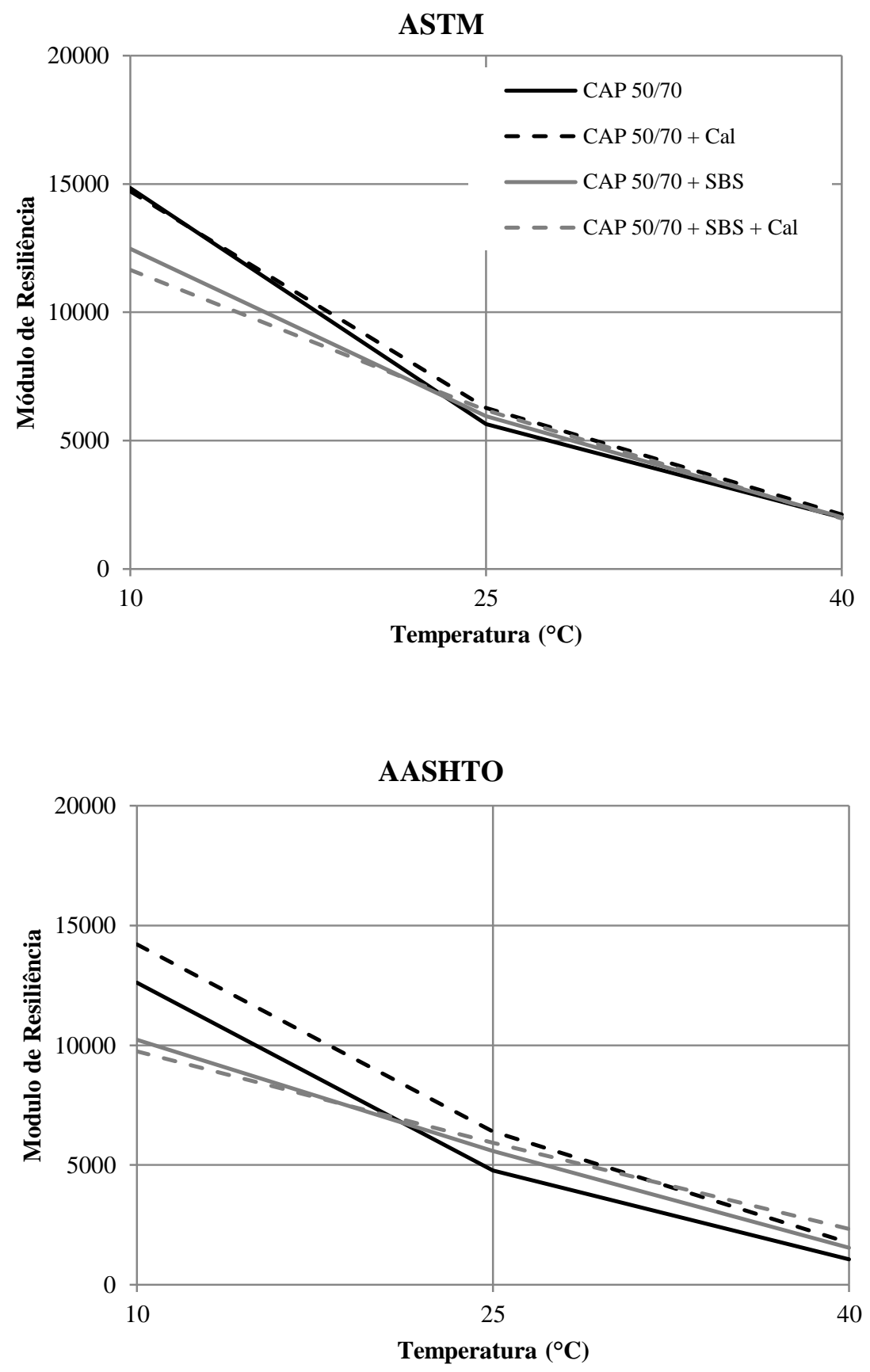

FIGURA 4.3: MR versus Temperatura

A partir da análise dos gráficos da figura 4.3, pode-se dizer que:

- A principal variável responsável pela mudança de MR foi a temperatura,

- No intervalo de temperatura de 10 a $25^{\circ} \mathrm{C}$, as misturas com CAP 50/70 exibiram MR mais elevados que as com CAP 50/70+SBS, 
- No intervalo de temperatura de 25 a $40^{\circ} \mathrm{C}$, as misturas com CAP 50/70 e CAP 50/70+SBS parecem convergir para MR de mesma ordem,

- As misturas com CAP 50/70+SBS foram menos suscetíveis à temperatura que as com CAP 50/70, o que pode ser inferido pela menor inclinação das curvas de MR x temperatura no intervalo de 10 a $40^{\circ} \mathrm{C}$,

- Os envelhecimentos de curto e longo prazo (ASTM e AASHTO) não provocaram mudanças importantes no comportamento de MR x temperatura,

A mistura asfáltica com CAP 50/70+SBS, no intervalo de $10^{\circ} \mathrm{C}$ a $40{ }^{\circ} \mathrm{C}$, apresentou uma queda de cerca de $85 \%$ no MR, contra $91 \%$ da mistura com CAP 50/70; para as misturas asfálticas com cal essa relação ficou em 76\% para as com CAP 50/70+SBS, e 87\% para as com CAP 50/70.

O comportamento dos parâmetros de rigidez em função da variação de temperatura também foi analisado. A figura 4.4 mostra os comportamentos da RR e do atraso em função de MR, sendo que a variação de MR é decorrente da variação da temperatura. Observando-se o comportamento das curvas das regressões tem-se que, com a redução da temperatura e consequente aumento de MR, há uma redução de RR e do atraso. Esse comportamento concorda com os observados por Furlan et. al. (2006) e por Pilatti et al. (2010), ou seja, alguma redução do atraso pode ser entendida como uma resposta mais rápida ao carregamento e alguma redução de RR significa que a recuperação é mais rápida no descarregamento. Esse comportamento é bastante coerente, uma vez que o aumento de MR, em função da redução da temperatura, torna a mistura mais rígida e mais elástica. Deve se destacar a qualidade dos ajustes da regressão linear, principalmente em relação ao atraso, que exibiu $\mathrm{R}^{2}=0,92$. 

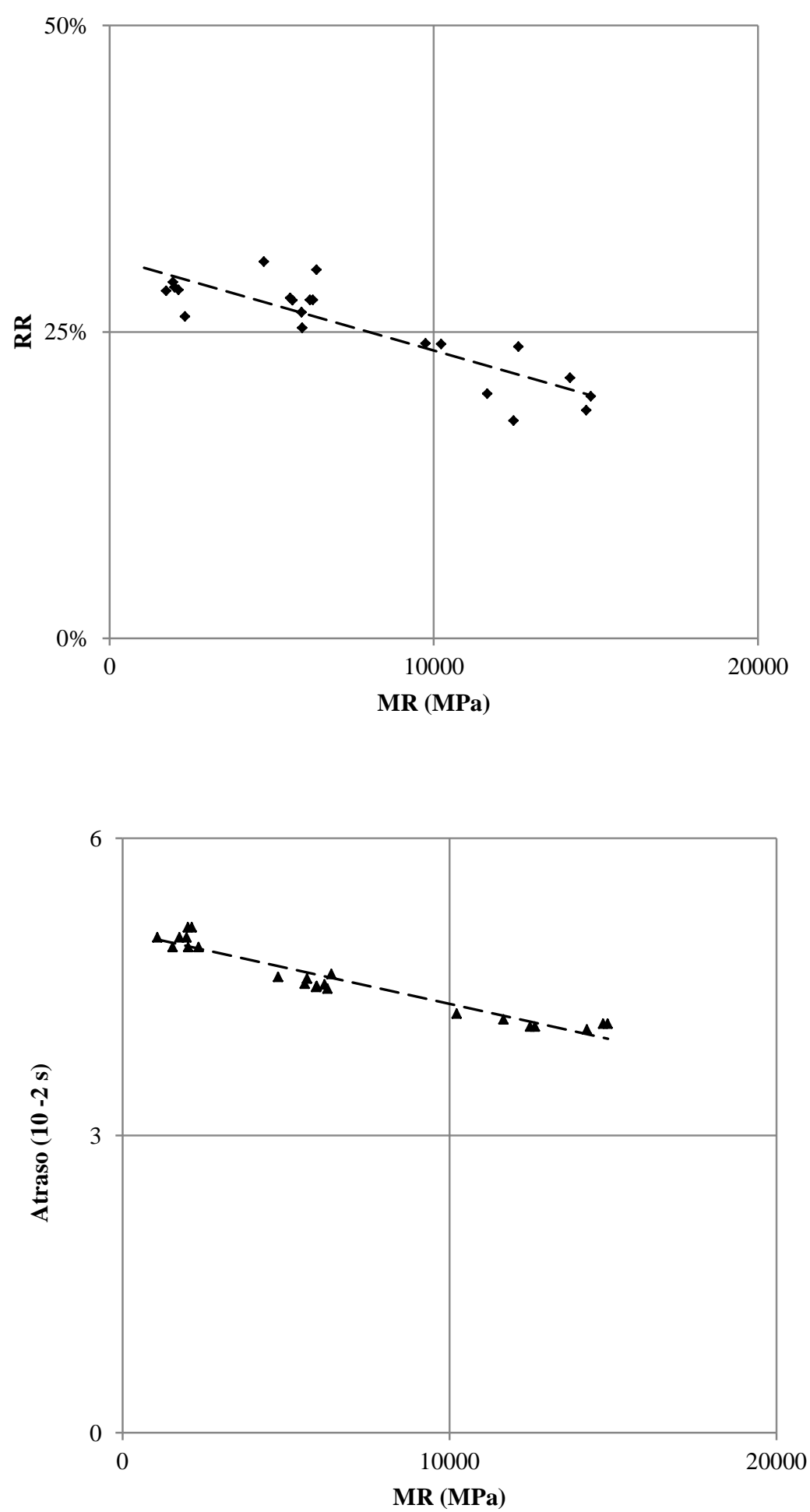

FIGURA 4.4: Comportamento dos parâmetros de rigidez em função de MR 
A figura 4.5 mostra o comportamento de RR em função da variação de temperatura, nela se observa algumas tendências com relação às variáveis do programa:

- a temperatura é um fator importante para a variação de RR, e teve efeito mais intenso sobre RR na faixa de temperatura mais amena;

- o envelhecimento em longo prazo (misturas AASHTO) pode ter contribuído para um discreto aumento de RR;

- as misturas produzidas com asfalto modificado exibiram RR menores que as produzidas com asfalto convencional;

- a cal propiciou o aumento de RR, principalmente na faixa de temperatura mais alta.

É importante ressaltar que RR tendeu a se estabilizar com o aumento da temperatura para a algumas misturas testadas, exceto para as misturas ASTM e AASHTO com CAP 50/70 e para a mistura AASHTO com CAP 50/70+SBS; os comportamentos diferentes exibidos por essas misturas podem ser considerados vantajosos, pois o aumento da temperatura não implicou em uma mistura de recuperação mais lenta, ao contrário, as misturas apresentaram respostas mais rápidas (elástica) com o aumento da temperatura. Essa observação pode ser explicada quando se considera que o envelhecimento, tanto em curto quanto em longo prazo, é responsável por algum enrijecimento da mistura asfáltica, ou ainda que o asfalto modificado pode contribuir para respostas mais rápidas em faixas de temperaturas mais altas. 


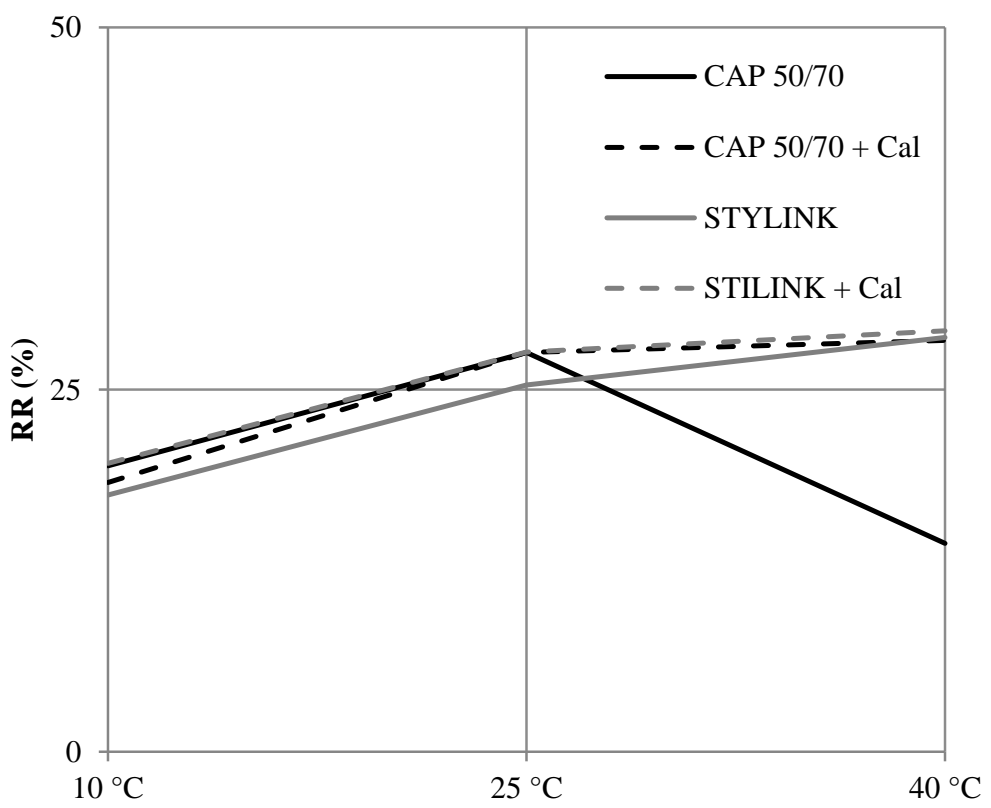

Temperatura $\left({ }^{\circ} \mathrm{C}\right)$

(Misturas ASTM)

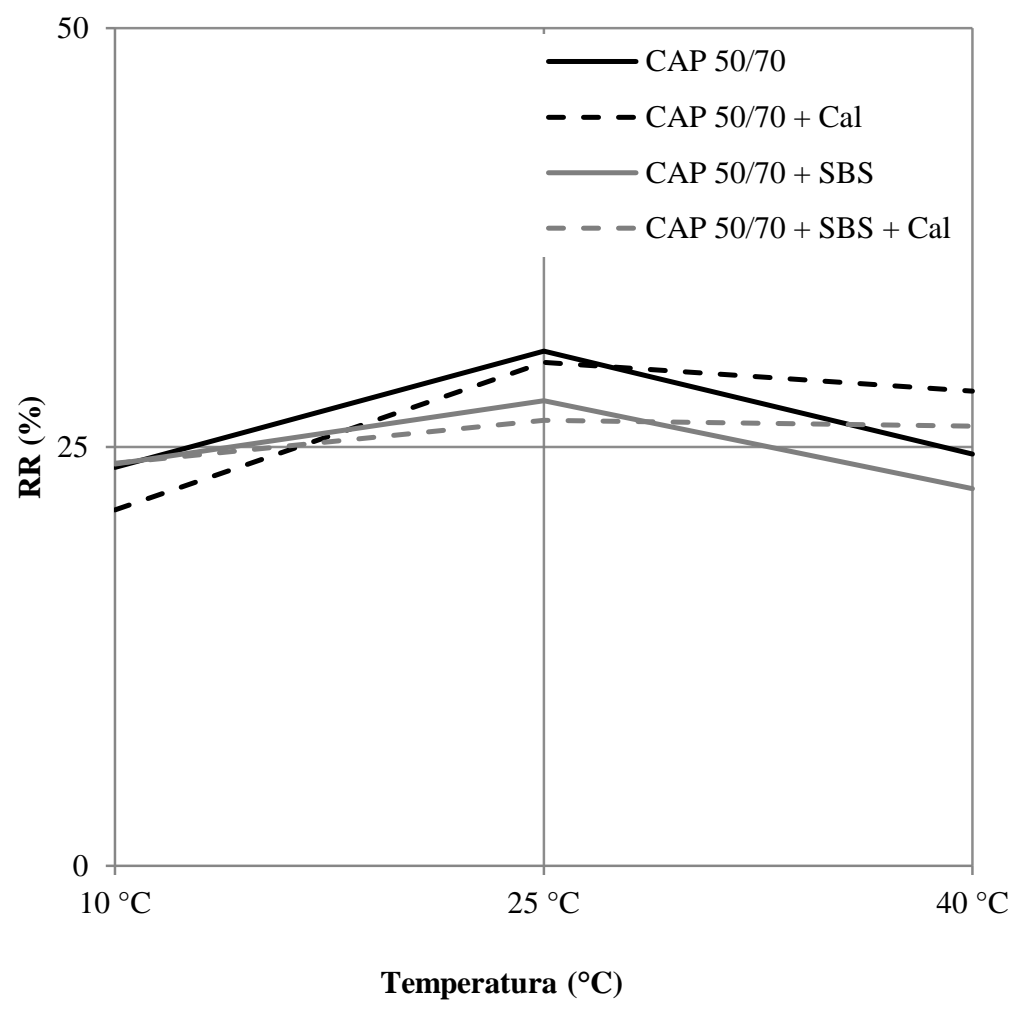

(Misturas AASHTO)

FIGURA 4.5: RR versus Temperatura 
No que se refere à adição da cal, a RR aumenta quando se adiciona a cal nas misturas com CAP 50/70 e CAP 50/70+SBS, principalmente no intervalo de temperatura de 25 a $40^{\circ} \mathrm{C}$. Aparentemente, a cal trouxe algum benefício quando adicionadas às misturas AASHTO, pois atuou reduzindo discretamente o RR no intervalo de 25 a $40^{\circ} \mathrm{C}$; é possível que esse benefício seja uma particularidade da combinação dos fatores adição de cal e envelhecimento em longo prazo.

A figura 4.6 mostra o comportamento do atraso em função da variação de temperatura, nela se observa algumas tendências com relação às variáveis do programa:

- a temperatura é um fator importante para a variação do atraso;

- os envelhecimentos em curto e longo prazo tiveram influência muito pequena no atraso;

- as misturas produzidas com asfalto modificado exibiram atrasos menores que as produzidas com asfalto convencional;

- não se observou tendência clara da adição de cal sobre o atraso das misturas testadas.

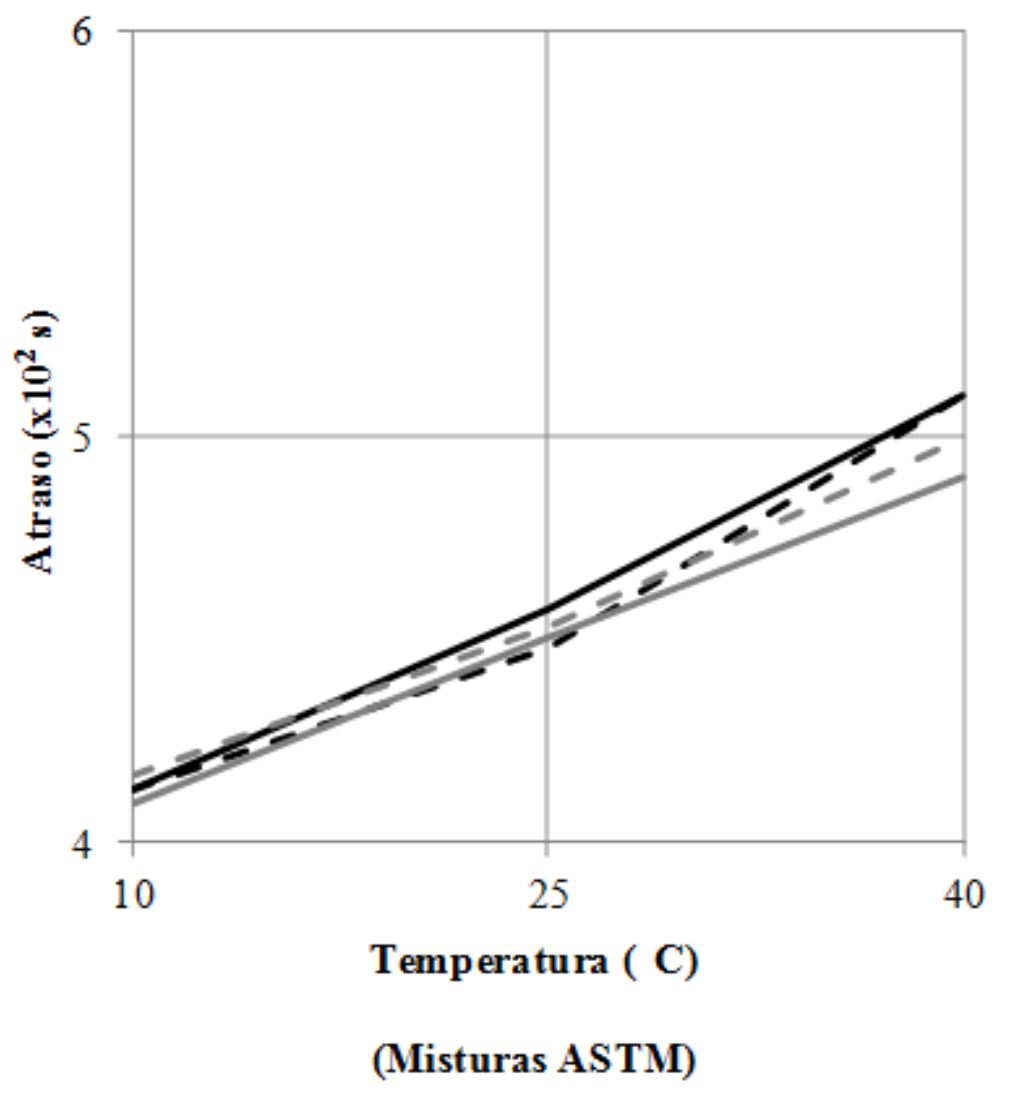




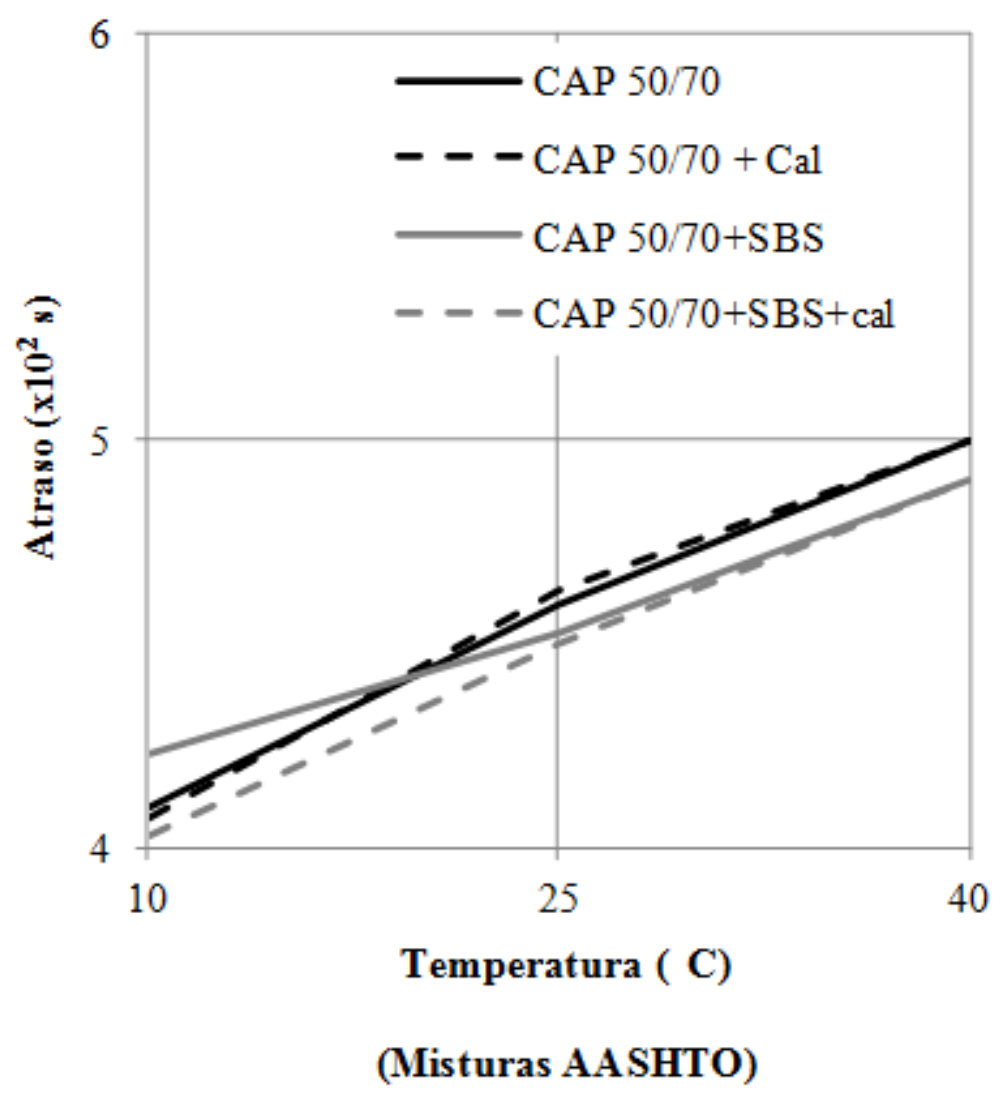

FIGURA 4.6: Atraso versus Temperatura

Quanto ao atraso, pode-se dizer que o aumento da temperatura causou o aumento do atraso, o que representa que as misturas asfálticas testadas tendem a apresentar respostas mais lentas frente ao carregamento em temperaturas mais altas $\left(25\right.$ a $\left.40^{\circ} \mathrm{C}\right)$. De modo geral houve um aumento de $20 \%$ no tempo de atraso, com o aumento da temperatura de $10{ }^{\circ} \mathrm{C}$ para $40{ }^{\circ} \mathrm{C}$.

No que se refere ao tipo de asfalto, notou-se que as misturas com CAP 50/70+SBS exibiram atrasos menores que as com CAP 50/70, o fato de a resposta ao carregamento ser mais rápida para o asfalto modificado pode ser explicada pela presença do polímero SBS que pode melhorar características de flexibilidade e rigidez das misturas asfálticas em amplos intervalos de temperatura. Não foi possível observar tendência clara de comportamento com a variação dos fatores envelhecimento em curto e longo prazo (ASTM e AASHTO) e adição de cal. 


\subsubsection{Suscetibilidade ao dano por umidade das misturas asfálticas}

A avaliação da resistência ao dano por umidade induzida que se apresenta neste item se baseia nos resultados de resistência à tração que as misturas asfálticas apresentaram antes e depois do condicionamento térmico preconizado pelas normas ASTM D 4867 e AASHTO T 283. É importante lembrar que, embora o ciclo de congelamento seja um procedimento opcional no método da ASTM, nessa pesquisa optou-se pela sua execução, como artifício para se observar o efeito do modo de produção das misturas, que contemplam envelhecimento em curto (ASTM) e longo prazo (AASHTO). Além disso, foi adotado um mesmo intervalo de grau de saturação (Gs), de 70 a $80 \%$, para as misturas independente do método, dessa forma, tentou-se evitar a influência dessa variável.

A Tabela 4.6 apresenta os resultados de RT e RRT de todas as misturas testadas, os valores apresentados são valores médios das tréplicas das condições experimentais. Os CPs dos grupos de controle (G1) e condicionado (G2) foram selecionados a partir da apreciação dos volumes de vazios (Vv). De modo geral, conseguiu-se estabelecer grupos de características volumétricas e de saturação similares, porém, como se observa na Tabela 4.6, as misturas produzidas de acordo com as recomendações da AASHTO (envelhecimento em longo prazo) apresentaram $\mathrm{Vv}$, em média, 0,4\% maiores.

O que se pode observar dos valores de RT apresentados na Tabela 4.6 é que nem sempre houve redução da propriedade em consequência do condicionamento térmico, isso implicaria dizer que as misturas asfálticas se tornam mais resistentes. De fato, o ganho de RT exibido por algumas misturas asfálticas foi de, no máximo, $10 \%$ maior que a RT original.

TABELA 4.6: RT e RRT das misturas testadas

\begin{tabular}{lccccc|ccccc}
\hline & \multicolumn{3}{c}{ ASTM } & \multicolumn{5}{c}{ AASHTO } \\
\hline & $\mathbf{V v}$ & $\mathbf{G s}$ & $\mathbf{R T}_{\mathbf{G 1}}$ & $\mathbf{R T}_{\mathbf{G} 2}$ & $\mathbf{R R T}$ & $\mathbf{V v}$ & $\mathbf{G s}$ & $\mathbf{R T}_{\mathbf{G 1}}$ & $\mathbf{R T}_{\mathbf{G} 2}$ & RRT \\
& $(\%)$ & $(\%)$ & $(\mathbf{M P a})$ & $(\mathbf{M P a})$ & $(\boldsymbol{\%})$ & $(\boldsymbol{\%})$ & $(\boldsymbol{\%})$ & $(\mathbf{M P a})$ & $(\mathbf{M P a})$ & $(\%)$ \\
\hline CAP 50/70 & 6,9 & 71,6 & 1,41 & 1,03 & 73 & 8,3 & 76,6 & 1,30 & 1,07 & 83 \\
CAP 50/70+Cal & 6,7 & 76,6 & 1,40 & 1,51 & 108 & 7,8 & 75,5 & 1,49 & 1,53 & 102 \\
CAP 50/70+SBS & 6,9 & 71,1 & 1,73 & 1,90 & 110 & 8,3 & 74,1 & 1,58 & 1,67 & 106 \\
CAP 50/70+SBS+Cal & 6,6 & 70,5 & 1,62 & 1,69 & 104 & 6,7 & 73,1 & 1,76 & 1,88 & 107 \\
\hline
\end{tabular}


A figura 4.7 apresenta as RT antes e após o condicionamento de todas as misturas testadas. Essa figura é adequada para notar alguma tendência de comportamento, ou seja, se há alguma particularidade associada à mudança do tipo de asfalto ou da adição de cal, no entanto, o comportamento observado após o condicionamento foi o mesmo identificado nas propriedades originais. Há, porém, uma discreta diferença de comportamento entre os métodos, para as misturas envelhecidas em curto prazo (ASTM), a que apresentou maior RT antes e após o condicionamento foi a mistura com CAP 50/70+SBS+cal, enquanto que para as misturas envelhecidas em longo prazo (AASHTO) a mistura de maior RT foi a com CAP 50/70+SBS.

Considerando que o desvio de grupo (razão entre desvio padrão e média do grupo) foi de, no máximo, $11 \%$, sendo seu valor médio de $7 \%$, pode-se dizer que o incremento de RT em $10 \%$ não se caracteriza necessariamente como ganho de resistência, porque o valor da propriedade é influenciado por fontes de erros experimentais como a heterogeneidade dos CPs e do grupo de CPs (características volumétricas e de saturação) e desvios de execução do ensaio (aquisição de dados e variação de temperatura). 

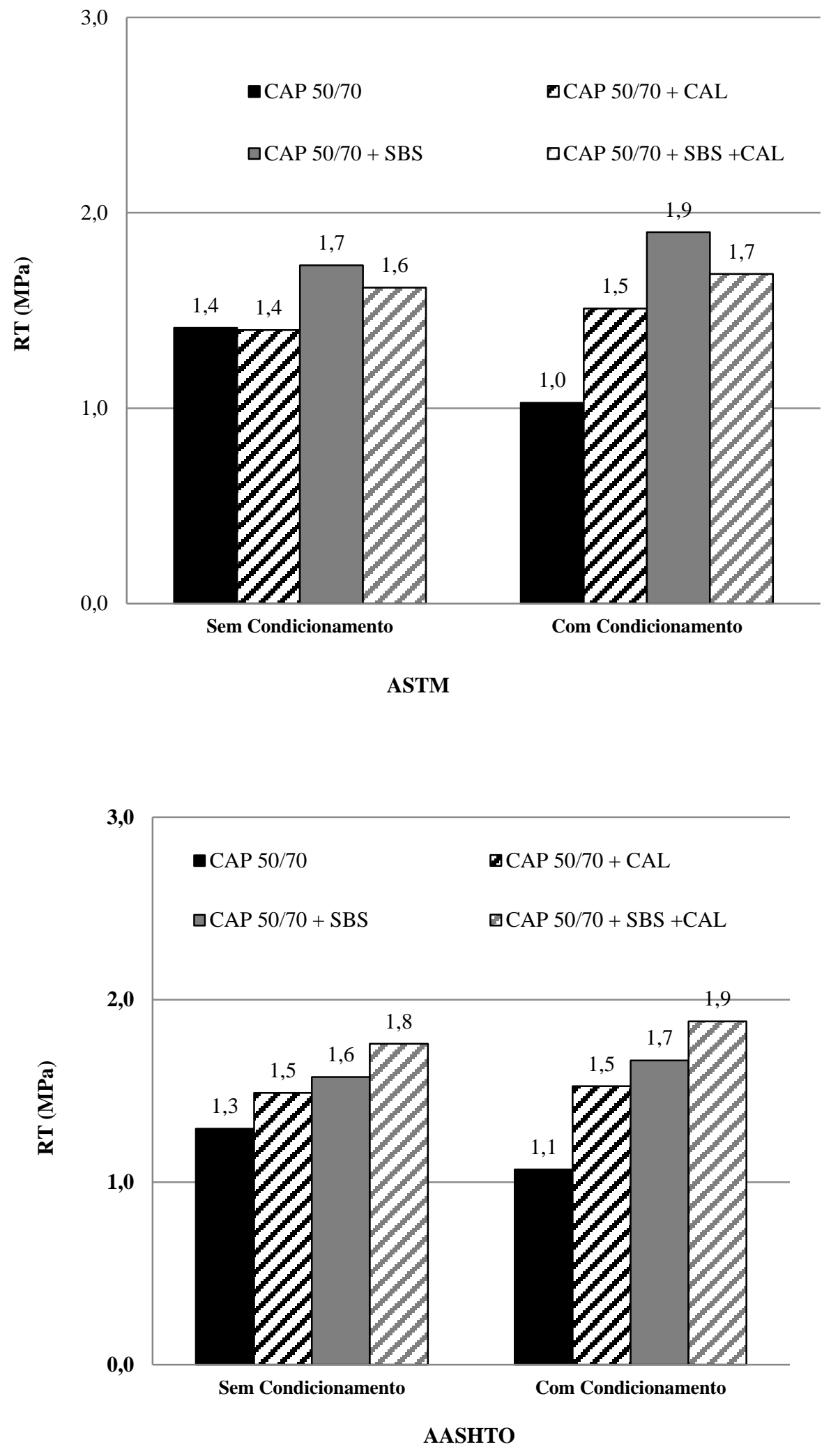

FIGURA 4.7: RT do grupo de controle e condicionado 
A figura 4.8 apresenta as relações de resistência à tração (RRT) das misturas testadas a partir dos métodos da ASTM e da AASHTO. É importante destacar que a norma da ASTM D 4867 preconiza que a mistura asfáltica é considerada sensível ao dano por umidade induzida quando a RRT é menor que $70 \%$. Por outro lado na norma da AASHTO T 283, para uma mistura asfáltica ser considerada suscetível ao dano por umidade induzida é necessário que a RRT seja inferior a $80 \%$ (para o caso das misturas terem sido dosadas e moldadas segundo o método Superpave). Portanto, de acordo com os resultados dos dois métodos, nenhuma mistura testada seria considerada suscetível ao dano por umidade.

No entanto, os valores de RRT das misturas com CAP 50/70 de ambos os métodos se encontram no limiar dos valores limites. Como já discutido, os valores de RT podem ter incorporados erros experimentais e o fato de os resultados de RRT estarem somente 3\% acima do valor limite (de ambos os métodos) é uma constatação que preocupa.

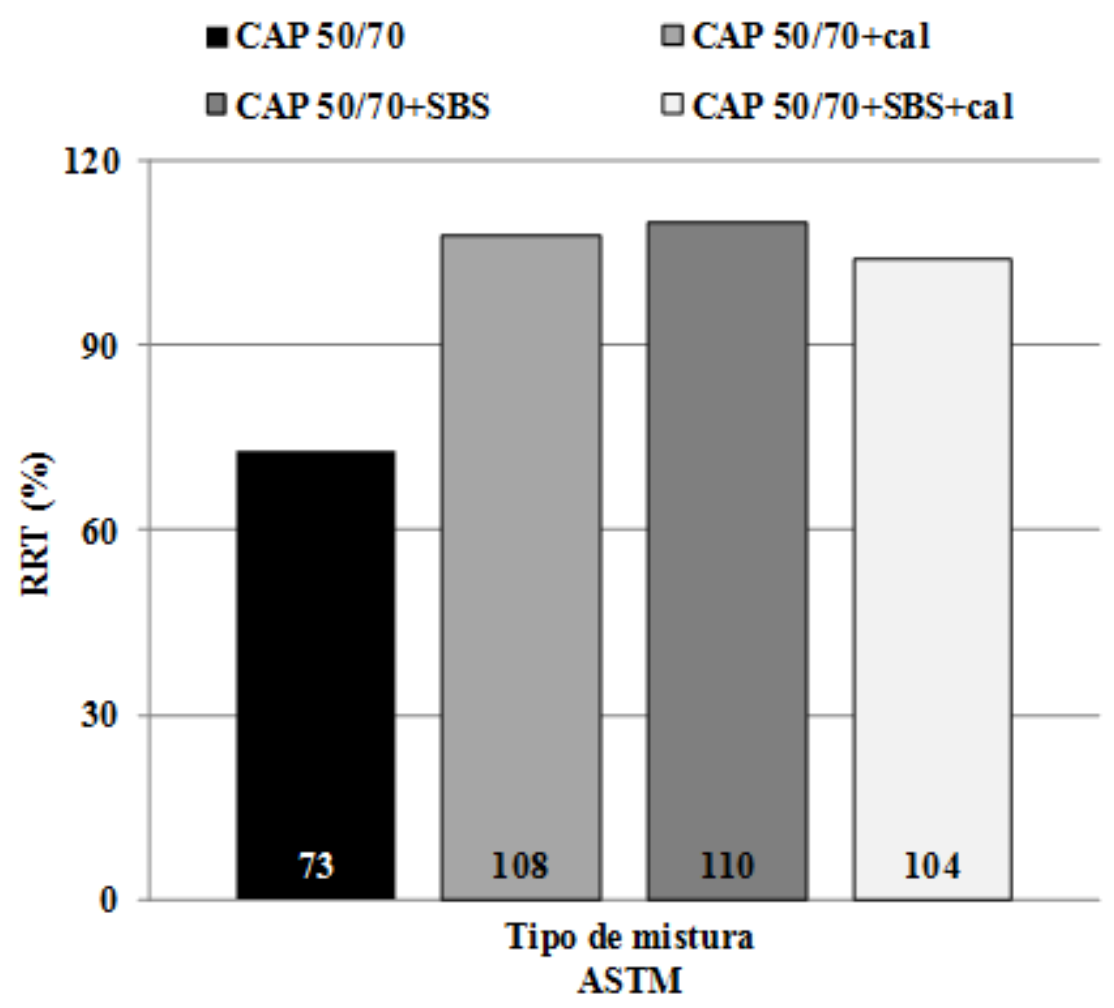




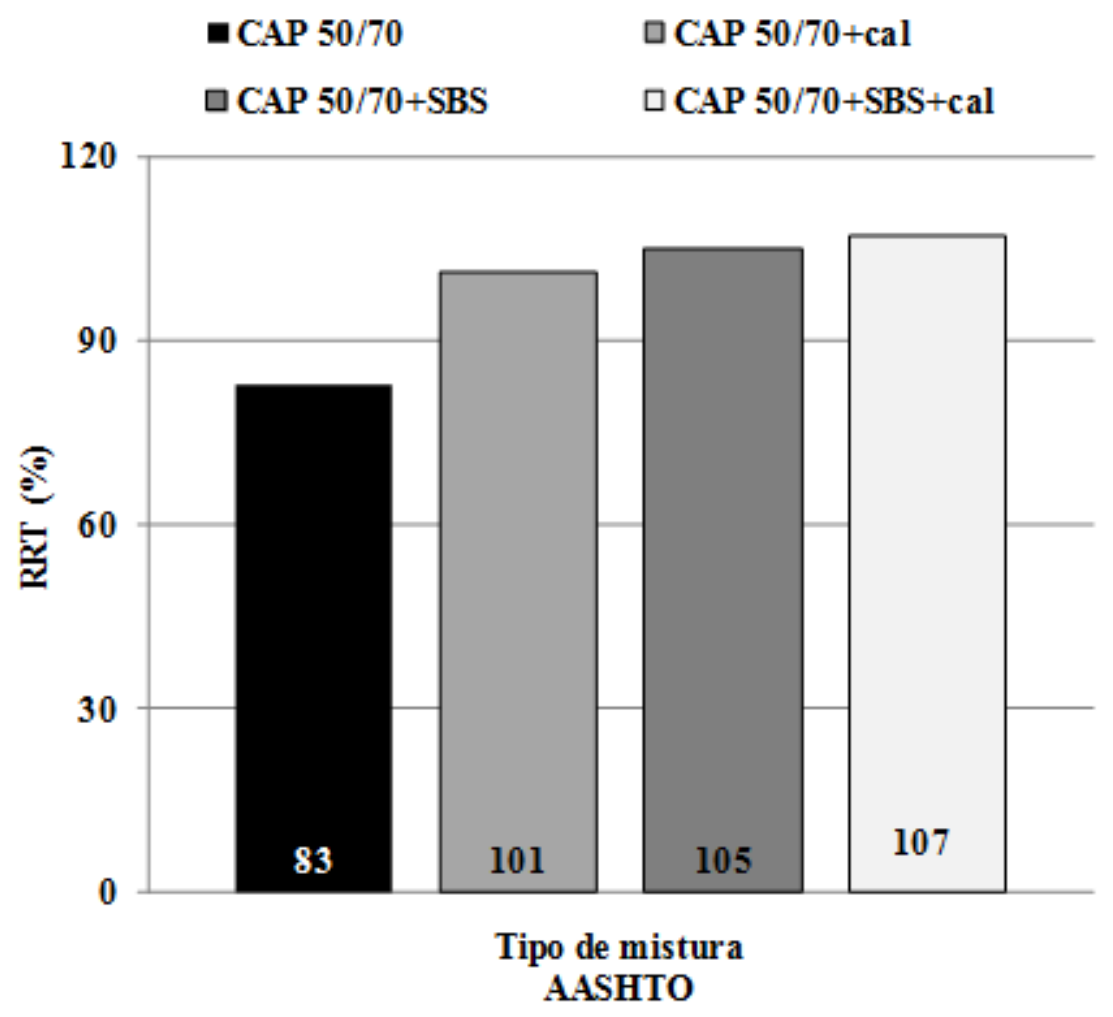

FIGURA 4.8: RRT das misturas testadas

A figura 4.8 permite algumas observações com relação ao efeito das variáveis, por exemplo:

- o modo de produção da mistura não contribuiu para produzir misturas de propriedades originais diferentes e, após o condicionamento, as tendências de comportamento são semelhantes;

- a modificação do asfalto com o polímero SBS tornou a mistura mais resistente à ação da água; e

- a adição de cal na mistura com CAP 50/70 tornou a mistura mais resistente à ação da água.

Uma importante constatação a partir da apreciação dos resultados dos ensaios ASTM D 4867 e AASHTO T 283 foi que esses procedimentos permitem acessar o efeito da mudança das variáveis relacionadas aos materiais, por exemplo, mudança do tipo de asfalto e presença ou não de cal, sendo, por isso, apto para a avaliação (i) da viabilidade dos materiais empregados em misturas ou (ii) da eficiência de aditivos melhoradores de adesividade. 
No entanto, não foi possível constatar se um ensaio é melhor que outro quanto à adequação da previsão da suscetibilidade ao dano por umidade em curto ou longo prazo, pois os resultados apresentaram as mesmas tendências, restando ainda a dúvida se os procedimentos de produção das misturas asfálticas são realmente simuladores dos envelhecimentos em curto e em longo prazo.

\subsection{Avaliação visual}

Conforme recomendado em norma, após o ensaio de resistência foram feitas algumas observações visuais nas superfícies de ruptura dos CPs, com o intuito de verificar a ocorrência de quebra de agregado, descolamento da película asfáltica e outros observações pertinentes. No Anexo II encontram compiladas as planilha de ensaio, onde constam os resultados de propriedades volumétricas e mecânicas, registros fotográficos e comentários sobre impressões e avaliações visuais.

Com o registro fotográfico identificam-se os danos provocados pelo condicionamento dos corpos-de-prova. A figura 4.9 apresenta algumas fotos das superfícies de ruptura dos CPs de misturas com CAP 50/70 sem e com cal, para os dois modos de preparo (ASTM e AASHTO).

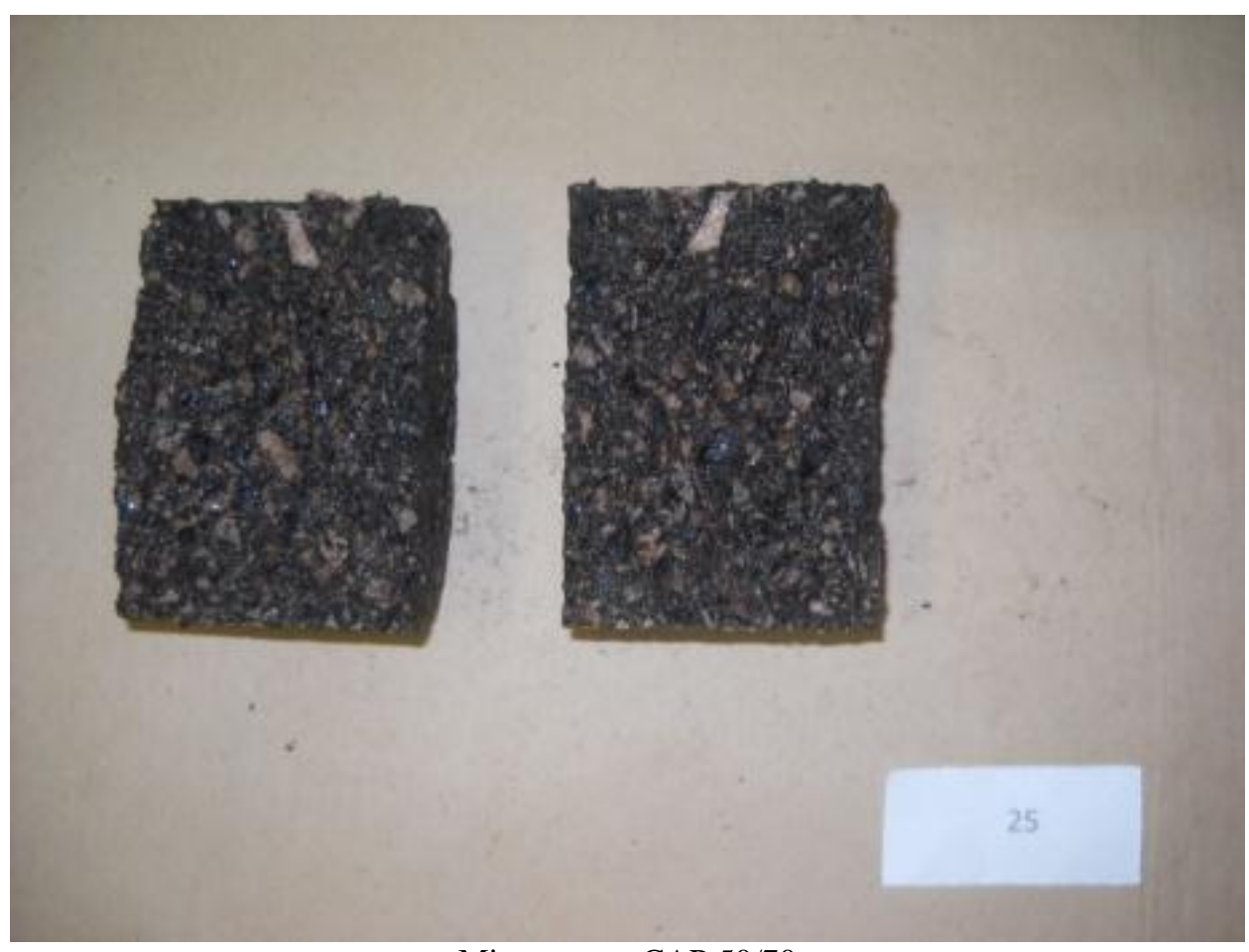

Mistura com CAP 50/70 
Modo de produção: ASTM

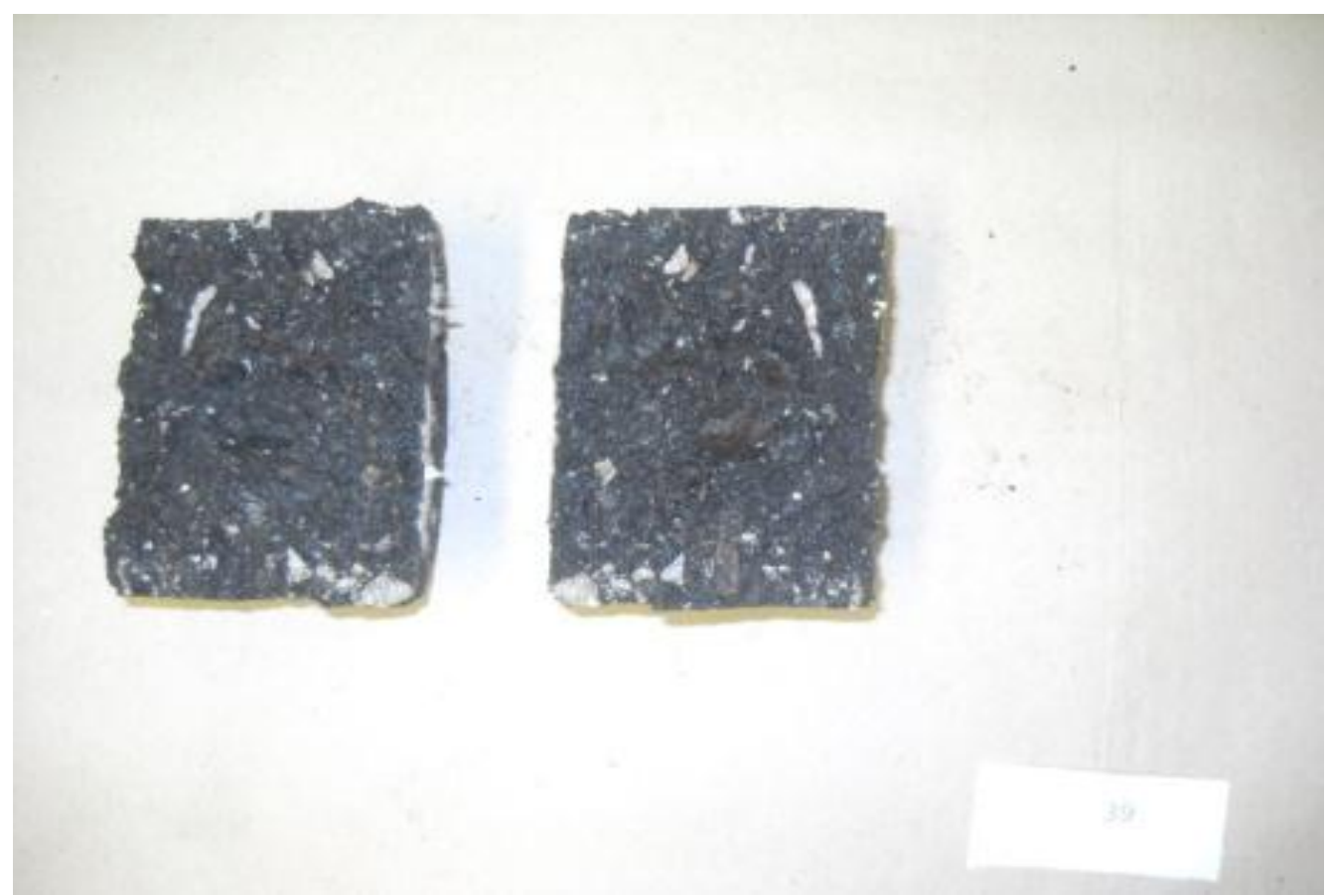

Mistura com CAP 50/70 + cal

Modo de produção: ASTM

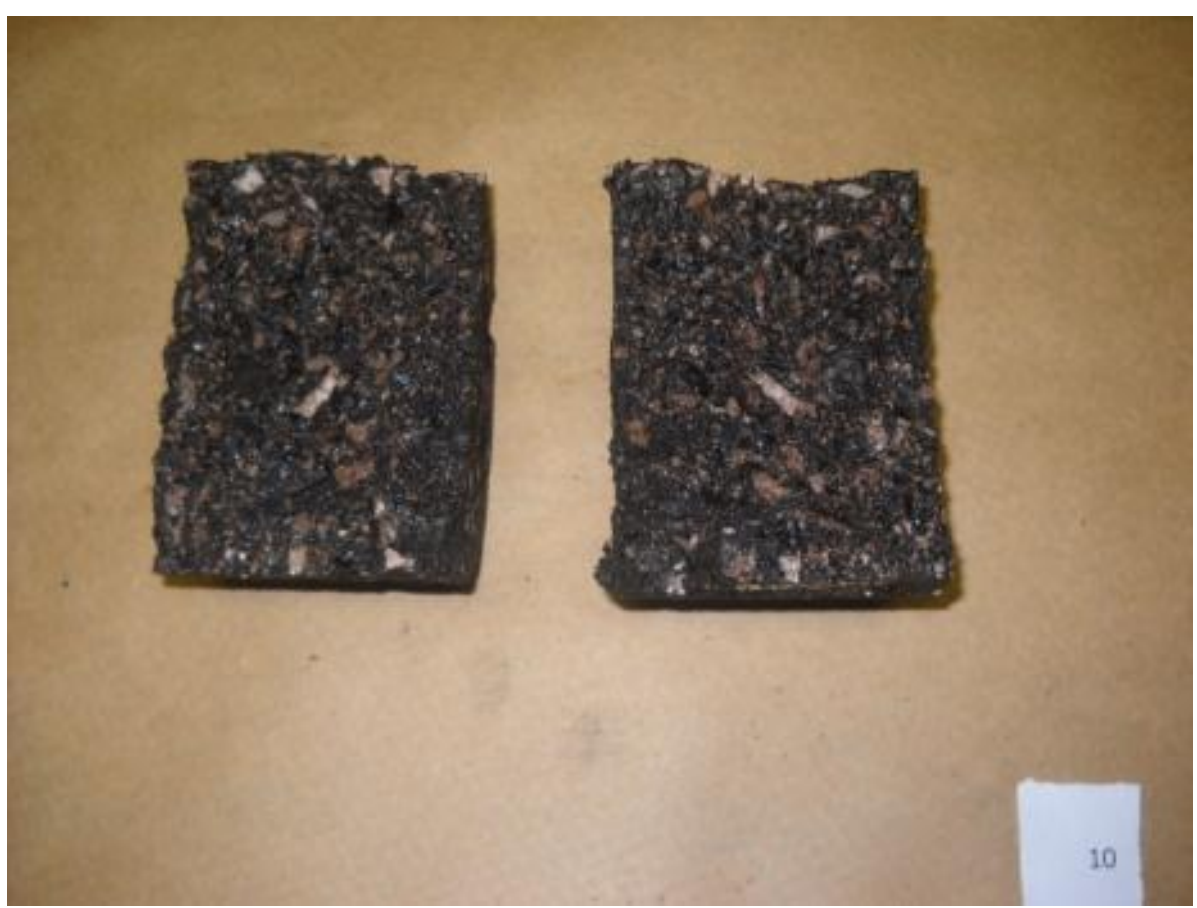

Mistura com CAP 50/70

Modo de produção: AASHTO 


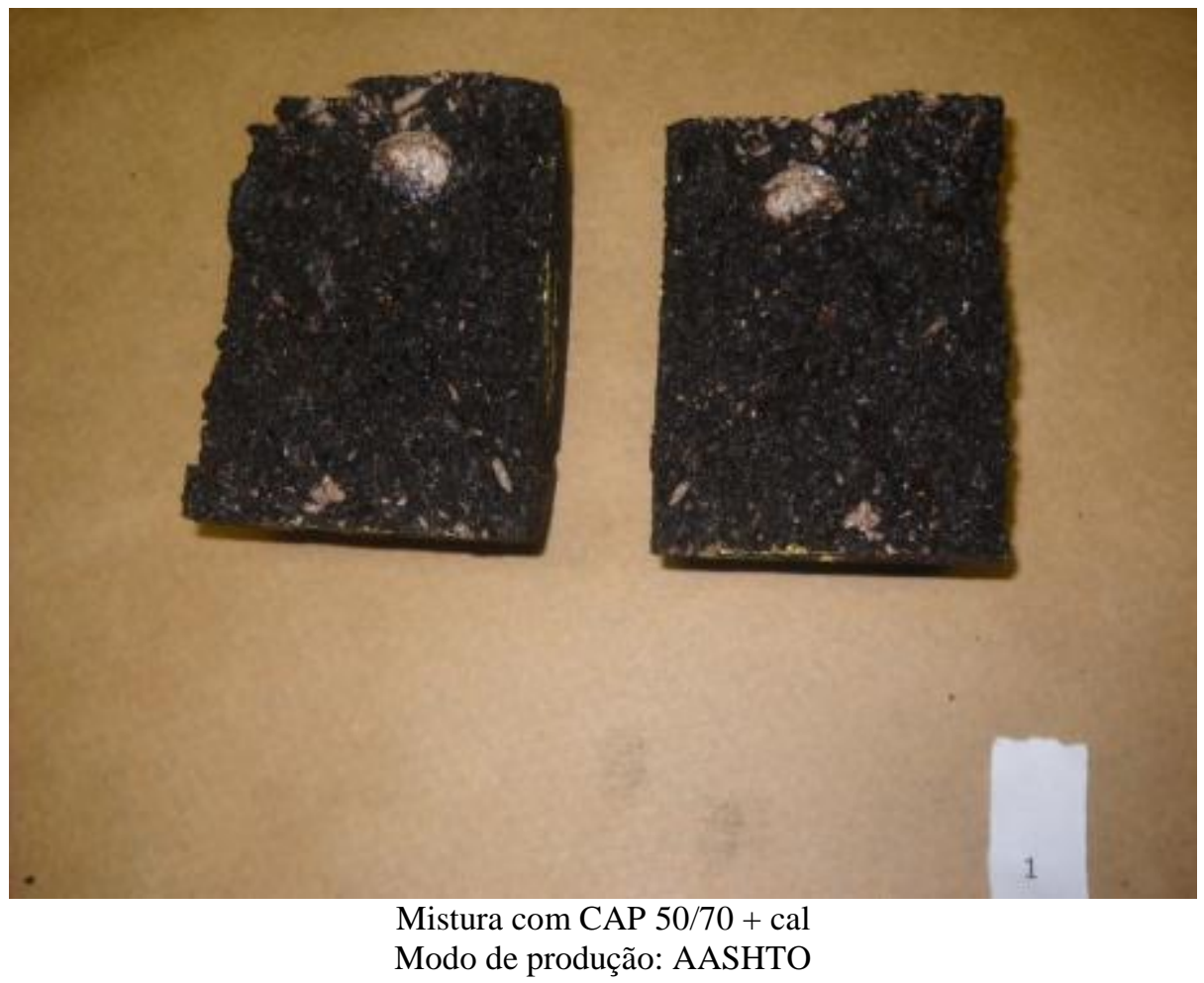

FIGURA 4.9: Registro fotográfico do plano de ruptura de CPs

As misturas que se aproximaram do valor limite para serem consideradas suscetíveis ao dano por umidade induzida foram as misturas com CAP 50/70, produzidas a partir dos métodos da ASTM e da AASHTO. Ainda em relação à figura 4.9, pode-se observar que na superfície de ruptura dos CPs são observados descolamentos e quebra de agregados localizada (frizo de aplicação de carga). Com a adição de cal, a mistura deixa de perder propriedade em função do condicionamento e na superfície de ruptura do $\mathrm{CP}$, passam a ser observados agregados quebrados, mostrando que a cal atuou aumentando a coesão da mistura asfáltica.

\subsection{Apreciação estatística dos resultados}

O tratamento estatístico dos resultados de ensaio foi desenvolvido com auxílio do software MiniTab Versão 14 e teve por objetivo observar o efeito e a intensidade dos efeitos das variáveis nas misturas asfálticas. Para a análise dos dados foi utilizada a ferramenta Planejamento de Experimentos (DOE), que permite identificar a variável significante ou não. 
Para isso são confrontados os valores de $p$-value com dado nível de significância (adotado $0,05)$, e os valores $F$ com dado nível de significância (adotado 4).

Assim sendo, as variáveis que foram consideradas significantes foram as que apresentaram valores de $\mathrm{P}<0,05$ e F>4 e, oportunamente, são apresentados a seguir os gráficos de efeitos principais e de interação das variáveis. É importante destacar que esse tratamento estatístico trabalha com a o valor médio de todas as respostas, podendo eventualmente ocorrer algum problema de interpretação.

Então, a análise da variância (ANOVA) foi feita para os resultados de RT e MR das misturas asfálticas antes do condicionamento e de RT das misturas asfálticas após o condicionamento. No anexo 3 são apresentados os relatórios gerados no MiniTab, com a ANOVA e os gráficos de efeitos principais e de interação de algumas das tentativas de modelação.

A figura 4.10 mostra o gráfico dos efeitos principais sobre MR, observando-se a inclinação da curva pode-se pensar, por exemplo, que o fator asfalto poderia ser um fator influente no valor de MR, mas são valores muito próximos. Dos dados do relatório (Anexo II - Relatório: Significância, efeitos principais e de interação de propriedades originais das misturas testadas) observa-se que nenhum dos fatores apresentou $\mathrm{F}>4$, como a condição de aceitação da significância é simultânea, conclui-se que nenhum dos efeitos, principais e/ou de interação são significantes para os valores de $\mathrm{MR}_{\text {original. }}$ Em função disso, não foram apresentados os gráficos dos defeitos de interação. 


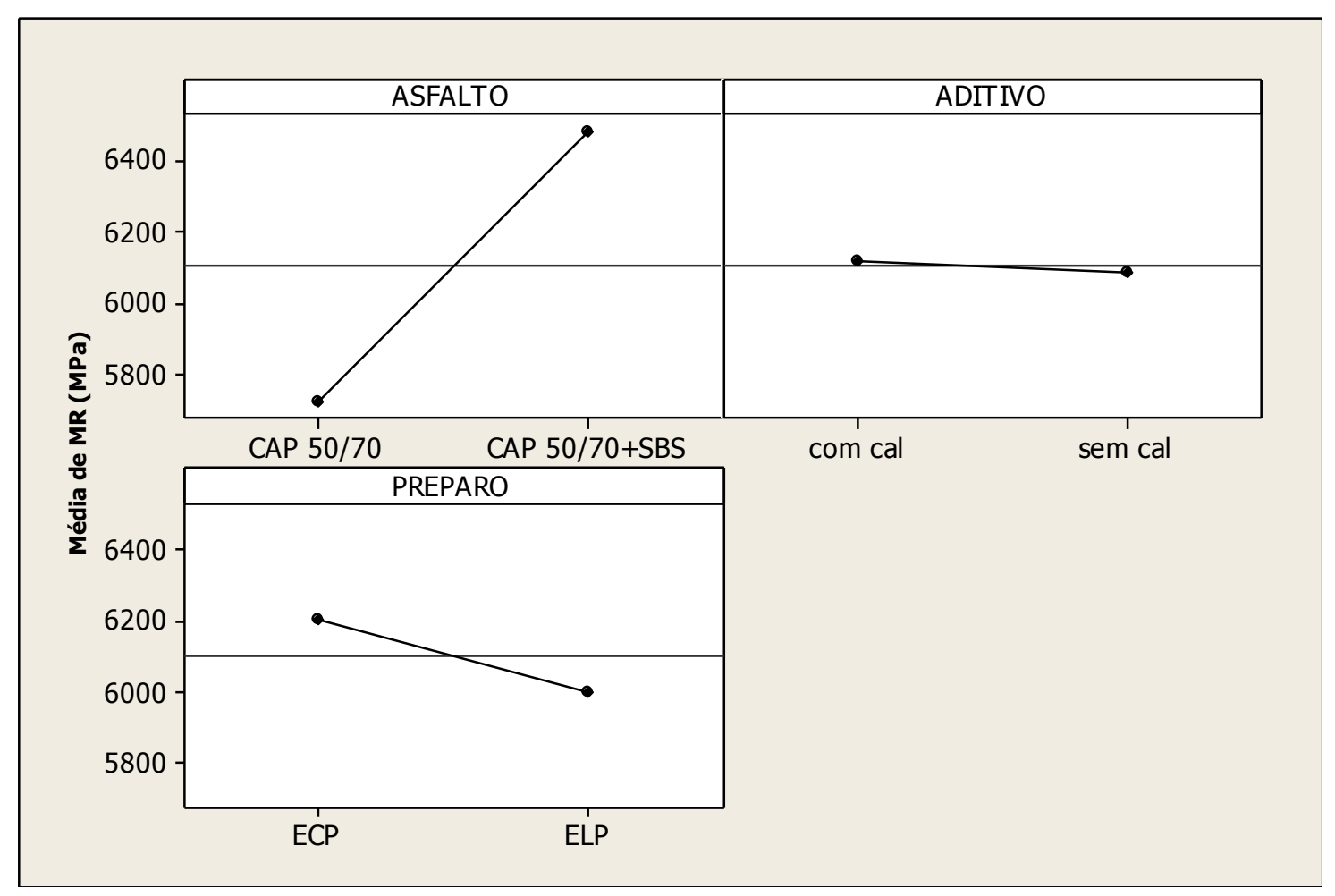

FIGURA 4.10: Efeitos principais das variáveis no valor médio de MR

A figura 4.11 mostra o gráfico dos efeitos principais sobre $\mathrm{RT}_{\text {original, }}$ nela se observa que a inclinação da curva de variação de valores médios de RT relacionada ao fator asfalto é a mais acentuada. Ao se recorrer ao relatório (Anexo III), constata-se que o fator significante nos valores de $\mathrm{RT}$ foi o tipo de asfalto, apresentando $\mathrm{F}=62,52$ e $\mathrm{P}=0,000$, e a interação dos efeitos do fator asfalto e do fator preparo, sendo $\mathrm{F}=13,08$ e $\mathrm{P}=0,002$. Para melhor visualizar o efeito de interação, a figura 4.12, mostra o gráfico de interação dos fatores sobre $\mathrm{RT}_{\text {original, }}$, 


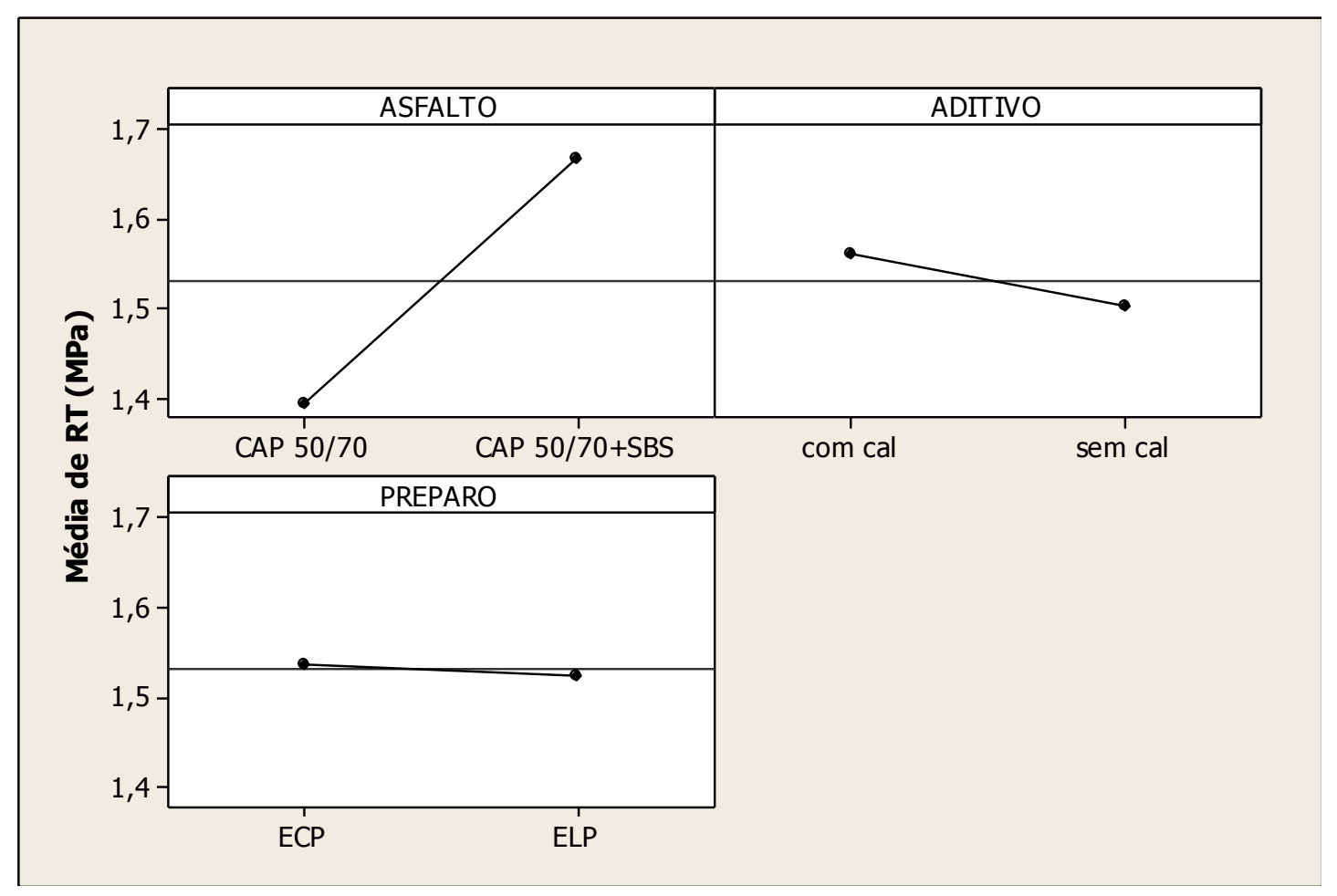

FIGURA 4.11: Efeitos principais das variáveis no valor médio de $\mathrm{RT}_{\text {original }}$

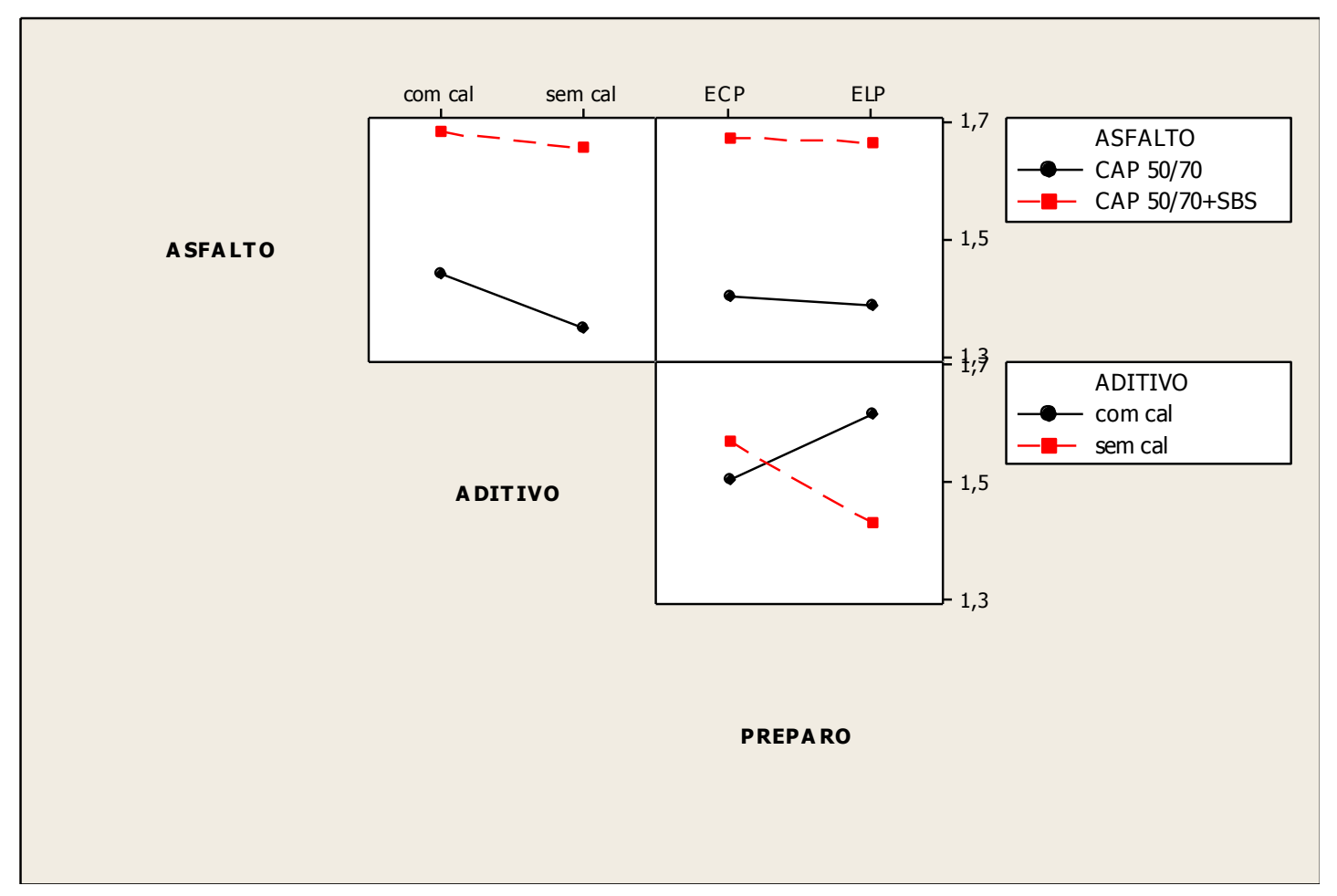

FIGURA 4.12: Efeitos de interações das variáveis no valor médio de $\mathrm{RT}_{\text {original }}$ 
A partir do tratamento estatístico foi possível confirmar o que se observou das análises de efeitos isolados apresentadas nos itens 4.2.1 e 4.2.3, além disso, foram ajustados modelos de previsão de RT em função das variáveis do programa experimental. São apresentados alguns dos modelos, um para $\mathrm{RT}_{\text {original. }} \mathrm{O}$ modelo apresentado não considera interações de nenhuma ordem.

$$
\mathrm{RT}_{\text {original }}=1,5316-0,13667 \cdot \mathrm{a}+0,03 \cdot \mathrm{b}+0,00583 \cdot \mathrm{c}
$$

Onde:

a é o tipo de asfalto, que varia nos níveis CAP 50/70 = 1 ou CAP 50/70+SBS = -1;

b é o tipo de aditivo, que varia nos níveis sem cal = -1 ou com cal = -;

c é o modo de preparo, que varia nos níveis $\mathrm{ECP}=1$ ou $\mathrm{ELP}=-1$.

Foram também avaliadas a significância e os efeitos principais e de interação para a RT após o condicionamento. Nas figuras 4.14 e 4.15 são apresentados os referidos gráficos, onde se observa que o condicionamento (nos níveis com e sem) foi inserido como variável. Essa foi a alternativa para evitar a utilização de valores médios de relação de resistência à tração (RRT) na modelação.

As figuras 4.13 e 4.14 mostram os gráficos dos efeitos principais e de interação sobre $\mathrm{RT}_{\text {pós cond. }}$. 


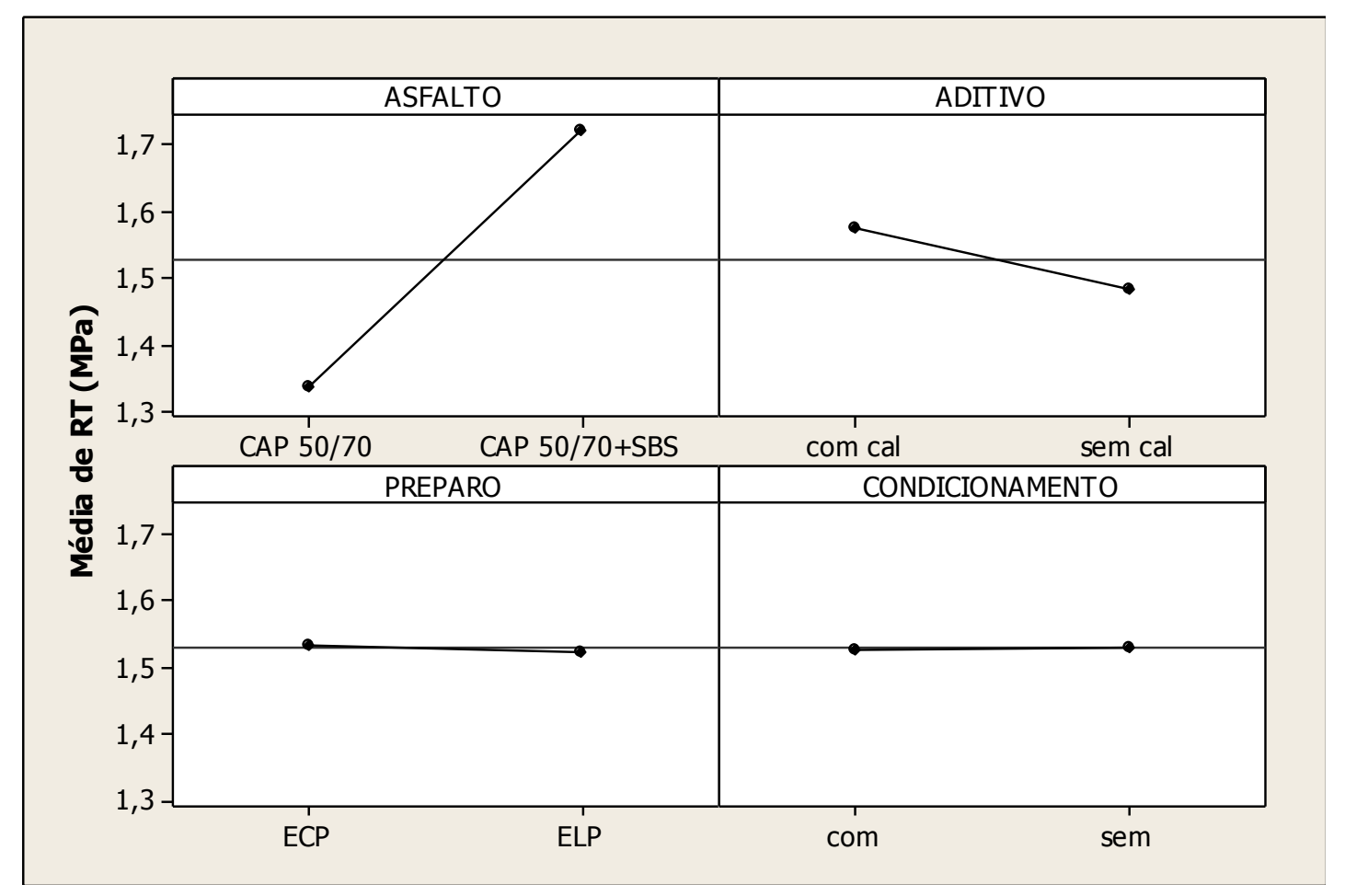

FIGURA 4.13: Efeitos principais das variáveis no valor médio de RT após o condicionamento

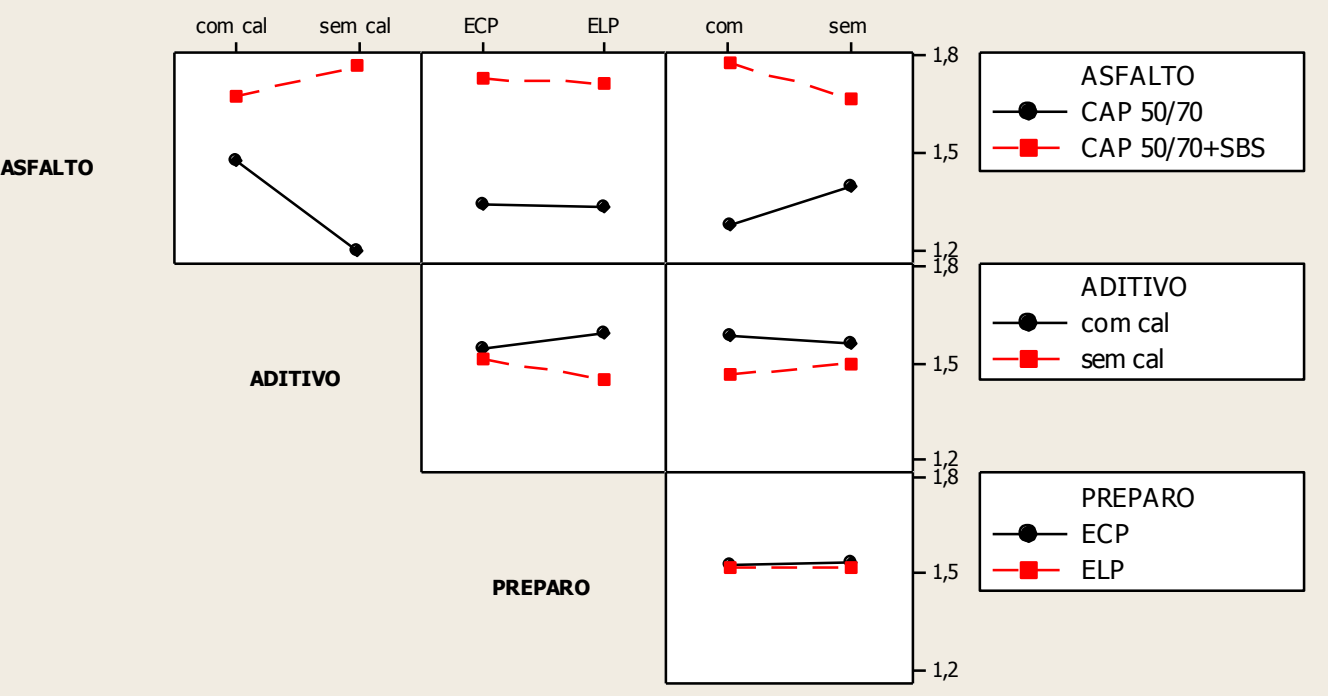

CONDICIONAMENTO

FIGURA 4.14: Efeitos de interações das variáveis no valor médio de RT após o condicionamento 
Da figura 4.13 se observa que as inclinações das curvas de variação de valores médios de RT relacionadas aos fatores asfalto e aditivo são mais acentuadas. A partir do relatório (Anexo II), constata-se que os fatores significantes nos valores de RT foram quatro: o tipo de asfalto ( $\mathrm{F}=90,74$ e $\mathrm{P}=0,000)$, aditivo $(\mathrm{F}=5,02$ e $\mathrm{P}=0,031)$ e a interação dos efeitos dos fatores asfalto e aditivo $(\mathrm{F}=20,73$ e $\mathrm{P}=0,000)$ e asfalto e condicionamento $(\mathrm{F}=7,92$ e $\mathrm{P}=0,008)$. Uma vez mais, para melhor visualizar os efeitos de interações, a figura 4.14, mostra o gráfico de

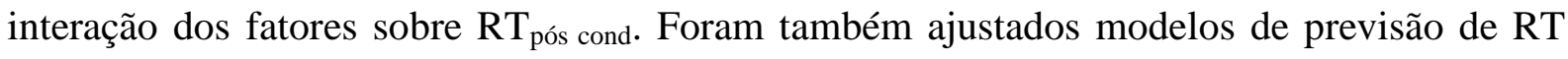
após o condicionamento em função das quatro variáveis de entrada. A seguir, na expressão

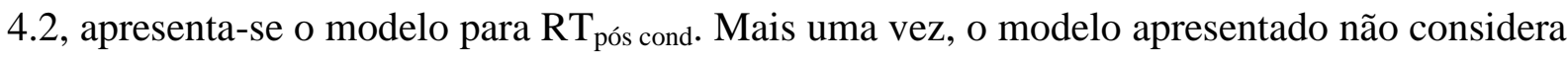
interações de nenhuma ordem.

$$
\mathrm{RT}_{\text {pós cond }}=1,5316-0,13667 \cdot \mathrm{a}+0,03 \cdot \mathrm{b}+0,00583 \cdot \mathrm{c}-0.00271 . \mathrm{d}
$$

Onde:

a é o tipo de asfalto, que varia nos níveis CAP 50/70 = 1 ou CAP 50/70+SBS = -1;

b é o tipo de aditivo, que varia nos níveis sem cal $=-1$ ou com cal $=1$;

c é o modo de preparo, que varia nos níveis $\mathrm{ECP}=1$ ou ELP $=-1$;

d é o condicionamento, que varia nos níveis sem $=1$ ou com $=-1$.

Os modelos lineares se basearam em variáveis qualitativas e em resultados experimentais, por isso, os coeficientes de regressão obtidos não foram muito altos: $67.91 \%$ para $\mathrm{RT}_{\text {original }}$ e a $58.39 \%$ para $\mathrm{RT}_{\text {pós cond. }}$ Se fossem consideradas interações de segunda ordem, os modelos teriam apresentado coeficientes maiores, em média. 


\section{CONCLUSÕES}

Esta pesquisa teve por objetivo entender melhor os efeitos de alguns fatores na suscetibilidade térmica e ao dano por umidade de misturas asfálticas densas à luz dos ensaios ASTM D 4867 e AASHTO T 283. Os fatores considerados no programa experimental foram: o tipo de ligante, o uso de aditivo, o tipo de preparo de misturas asfálticas.

Foram produzidas misturas asfálticas moldadas combinando os fatores mencionados que variaram em dois níveis, sendo que cada condição experimental foi treplicada. Os ensaios ASTM D 4867 e AASHTO T 283 foram escolhidos por terem por objetivo de avaliar a suscetibilidade ao dano por umidade. No entanto, o método da ASTM tornou-se conhecido por avaliar a sensibilidade à ação da água em curto prazo e o método da AASHTO em longo prazo. Os resultados foram analisados considerando o efeito das variáveis nas propriedades originais e após um ciclo térmico (congelamento-descongelamento) onde se pode constatar que:

\section{Quanto à absorção de asfalto pelo agregado}

- a simulação de envelhecimento em longo prazo do método da AASHTO levou a aumentos, da ordem de $300 \%$, das taxas de absorção de asfalto pelo agregado; 
- o modo de preparo foi o fator de efeito mais intenso na absorção de asfalto pelo agregado, seguido pelo tipo de asfalto e por último pela adição de cal;

- as misturas com asfalto modificado (CAP 50/70+SBS) apresentaram taxas de absorção de asfalto $40 \%$ maiores que as taxas das misturas com asfalto convencional (CAP 50/70);

- a cal atuou reduzindo a absorção de asfalto pelo agregado em cerca de $20 \%$ em relação às misturas sem cal.

\section{Quanto às propriedades originais das misturas asfálticas}

- nenhum dos fatores experimentais mostrou-se significante na variação de MR a $25^{\circ} \mathrm{C}$;

- o tipo de asfalto e a interação dos efeitos dos fatores asfalto e modo de preparo foram considerados importantes na variação de RT a $25^{\circ} \mathrm{C}$;

- na avaliação da suscetibilidade térmica das misturas, a principal variável responsável pela mudança de MR foi a temperatura e as misturas com CAP 50/70+SBS foram menos suscetíveis a temperatura que as com CAP 50/70,

Quanto à suscetibilidade ao dano por umidade das misturas asfálticas

- o modo de produção da mistura não contribuiu para produzir misturas mais suscetíveis ao dano por umidade, pois as misturas apresentaram as mesmas tendências de comportamento;

- a modificação do asfalto com o polímero SBS tornou a mistura mais resistente à ação da água; 
- a adição de cal manteve ou aumentou resistência à ação da água das misturas testadas.

Deve-se ressaltar que esses procedimentos permitiram acessar o efeito da mudança das variáveis relacionadas aos materiais mas não quanto à adequação da previsão da suscetibilidade ao dano por umidade em curto ou longo prazo, restando ainda a dúvida se os modos de preparo (ASTM e AASHTO) conseguem simular os envelhecimentos em curto e em longo prazo. 


\section{REFERÊNCIAS BIBLIOGRÁFICAS}

AASHTO T 283 (2002) - Resistance Of Compacted Asphalt Mixtures To Moisture-Induced Damage.

ASTM (1998) Test Method 04867, Effect ofmoisture on Asphalt Concrete Paving Mixtures. Publication in FHWA-RD-97-098.

AZEVEDO, P. N. e FILHO, A. F. S. (2009) - Asfalto Modificado com Polímero SBS. Universidade Católica de Salvador, UCSal Salvador - BA, 2009.

BALBO, J. T. (2007) - Pavimentação Asfáltica: Materiais, Projetos e Restauração.

BUNCHER, M. (2005) - Polyphosphoric Acid Modification of Asphalt. Asphalt Magazine. Fali, p. 38-40.

DNER - DEPARTAMENTO NACIONAL DE ESTRADAS DE RODAGEM. ME 035 (1994). Agregados: determinação da absorção e da densidade de agregado graúdo. Rio de Janeiro, 1999.

DNER - DEPARTAMENTO NACIONAL DE ESTRADAS DE RODAGEM. ME 078 (1994). Agregado graúdo - adesividade a ligante betuminoso. Departamento Nacional de Estradas de Rodagem, Rio de Janeiro.

DNER - DEPARTAMENTO NACIONAL DE ESTRADAS DE RODAGEM. ME 079 (1994). Agregado - adesividade a ligante betuminoso. Departamento Nacional de Estradas de Rodagem, Rio de Janeiro.

FHWA. Distress identification manual for the long-term pavement performance program. Federal Highway Administration. U.S. Department of Transportation $4^{\circ}$ Edition Revised. 154 p. Mclean, 2003. 
FURLAN, A.P. Considerações acerca da adesão e da suceptibilidade à umidade de misturas asfálticas densas à luz de algumas propriedades mecânicas. Tese (Doutorado). Universidade de São Paulo, EESC/USP, São Carlos, SP, 2006.

GOUVEIA, L. T., FURLAN, A. P., PARREIRA, A. B., FERNANDES JUNIOR, J. L., FABBRI, G. T. P., Considerações acerca da absorção de asfalto pelos agregados e sua influência na suscetibilidade à umidade. Anais do XVIII Congresso Nacional de Pesquisa e Ensino em Transporte, Associação Nacional de Pesquisa e Ensino em Transportes (ANPET), Florianópolis, SC, 2004.

HICKS, G. H. (1991) - Moisture damage in asphalt concrete- NCHRP Report 175. National Cooperative Highway Research.

KENNEDY, T. W.; McGennis, R. B.; Roberts, F. L. (1983 a) - Investigation of Moisture Damage to Asphalt Concrete and Affect on Field Performance - A Case Study. Transportation Research Record 911,p.158. Washinton, DC.

KENNEDY, T. W.; ROBERTS, F. L.; LEE, K. W. (1983 b) - Evalution of Moisture Effects on Asphalt Concrete Mixtures - Transportation Research Record 911, p. 134 - 143. Washington, DC.

KIM, Y. R.;. KHOSLA, N. P. KIM, N. (1992). Effects of aggregate type and gradation on fatigue and permanent deformation of asphalt concrete. Effects of Aggregates and Mineral Fillers on Asphalt Mixture Performance. Special Technical Publication STP 1147, American Society f Materials (ASTM), p. 310-328. Meininger, R. C., editor, Philadelphia.

LEITE, L. F. M., BITTENCOURT, C. P., NASCIMENTO, L. A. H., Efeito do ácido polifosfórico no desempenho dos ligantes rodoviários. Anais do XVIII Congresso Nacional de Pesquisa e Ensino em Transporte, Associação Nacional de Pesquisa e Ensino em Transportes (ANPET), Florianópolis, SC, 2004.

LESUEUR, D., LITTLE, D. N. AND EPPS, J. A. (1998). Effect of Hydrated Lime on the Rheology, Frature and Aging of Bitumen and Asphalt Mixtures, Paper Presented at Lhoist HMA Symposium, Dusseldorf, Germany.

LIBERATORI, L. A.; Constantino, R. S. (2006) - Melhoradores de adesividade para misturas asfálticas - Estado da Arte - $18^{\circ}$ Encontro de Asfalto - Rio de Janeiro RJ. 
LITTLE, D. N.; EPPS, J.A. (2001). The benefits of hydrated lime in hot mix asphalt, prepared for National Lime Association - The Versatile Chemical.

LOTTMAN, R. P. (1978) - Predicting Moisture-Induced Damage to Asphalt Concrete - Field Evaluation Phase. National Cooperative Higway Research Program, Transportation Research Board. UI Project 677- K297. p. 32 - 33.

LOTTMAN, R. P. (1982a) - NCHRP Report 192: Predicting Moisture-Induced Damage to Asphaltic Concrete. - Transportation Research Board, National Research Council. Washington, DC.

LOTTMAN, R. P. (1982b) - Laboratory Test Method for Predicting Moisture-Induced Damage to Asphalt Concrete. - Transportation Research Record 843, p. 88 - 95. Washington, DC.

MAJIDZADEH, K. e BROVOLD, F. N. (1968). State of the art: Effect of water on bitumenaggregate mixtures, Highway Research Board, Special Report No. 98, 77p.

MANUAL DO ASFALTO. Instituto do Asfalto. Série do Manual Nº 4 (MS-4), 1989.

MARTIN, J.V.; BAUMGARDNER, G. A new method to produce polymer asphalt with crumb rubber and polyphosphoric acid, combining recycling and performance. Asphalt Rubber - Proceedings, Brazili, Brazil, p.903-930, 2006.

MERCADO, E. A. (2007) - Influence of Fundamental Material Properties and Air Void Structure on Moisture Damage of Asphalt Mixes. - Texas A\&M University - 2007

ROBERTS, F. L.; KANDHAL, P. S.; BROWN, E. R.; LEE, D. Y.; KENNEDY, T. W. (1991) Hot Mix Asphalt Material, Mixture Design and Constrution. $1^{\circ}$ ed. NAPA Research and Education Foundation, National Center for Asphalt Tecnology - NCAT. Lanham, Maryland, EUA.

SOLAIMANIAN, M.; Kennedy, T. W. (2000) - Precision of the Moisture Susceptibility Test - Method Tex 531-C. Research Report 4909-1F. Center for Transportation Research, University ofTexas at Austin.

TAIRA, C.; FURLAN, A.P.; FABBRI, G.T.P. (2003). Avaliação do Efeito do Asfalto Modificado com Polímero nas Propriedades Mecânicas de Misturas Asfálticas Densas. XVII Congresso de Pesquisa e Ensino em Transportes ANPET, 2003 Rio de Janeiro, RJ.

TAYLOR, M.A.; KHOSLA, N.P. (1983) - Stripping on asphalt pavement: State ofthe art, TRR 911. 
TERREL, R. L.; AL-SWAILMI, S. (1993) - Role of Pessimum Voids Concept in Understanding Moisture Damage to Asphalt Concrete Mixtures - Transportation Research Record 1386, p. 31 - 37. Washington, DC.

TUNNICLIFF, D. G.; ROOT, R. E. (1984) - NCHRP Report 274: Use of Antistripping Additives in Asphalt ConcreteMixtures. - Transportation research Council, Washington, DC.

YOON, H. H.; TARRER, A. R. (1988). Effect of aggregate properties on stripping. Transportation Research Record 1171, p. 37-43. Washington, D.C. 
ANEXO I - PROPRIEDADES MECÂNICAS E PROPRIEDADE DE DANO POR UMIDADE 


\begin{tabular}{|c|c|c|c|c|c|c|c|}
\hline & $\mathbf{C P}$ & Composição & $\begin{array}{l}\text { Vv } \\
(\%)\end{array}$ & $\begin{array}{l}\text { MR }_{10} \text { TOTAL } \\
\text { NCHRP }\end{array}$ & $\begin{array}{c}\text { MR }_{10} \text { INSTANTANEO REAL } \\
\text { NCHRP }\end{array}$ & $\mathbf{R R}_{10}(\%)$ & $\operatorname{ATRASO}_{10}\left(10^{-2} \mathrm{~S}\right)$ \\
\hline \multirow{12}{*}{$\stackrel{0}{\stackrel{0}{3}}$} & 2 & CAP 50/70 + Cal & 7,7 & 10559 & 13790 & 23,4 & 4,1 \\
\hline & 5 & CAP 50/70 + Cal & 7,8 & 16509 & 20609 & 19,9 & 4,0 \\
\hline & 6 & CAP 50/70 + Cal & 7,8 & 15559 & 19549 & 20,4 & 4,1 \\
\hline & 8 & CAP 50/70 & 8,2 & 11641 & 15316 & 24,0 & 4,1 \\
\hline & 10 & CAP 50/70 & 8,4 & 13126 & 17254 & 23,9 & 4,1 \\
\hline & 11 & CAP 50/70 & 8,2 & 13088 & 17093 & 23,4 & 4,1 \\
\hline & 3 sty & CAP 50/70 + SBS + Cal & 7,0 & 10048 & 13246 & 24,1 & 4,0 \\
\hline & 4 sty & CAP 50/70 + SBS + Cal & 6,5 & 9528 & 12729 & 25,2 & 4,1 \\
\hline & 5 sty & CAP 50/70 + SBS + Cal & 6,7 & 9678 & 12539 & 22,8 & 4,0 \\
\hline & 9 sty & CAP 50/70 + SBS & 8,3 & 10321 & 13301 & 22,4 & 4,2 \\
\hline & 10 sty & CAP 50/70 + SBS & 8,2 & 10038 & 13241 & 24,2 & 4,2 \\
\hline & 11 sty & CAP 50/70 + SBS & 8,3 & 10331 & 13843 & 25,4 & 4,3 \\
\hline \multirow{12}{*}{$\sum_{i}$} & 25 & CAP 50/70 & 7,0 & 10015 & 12718 & 21,3 & 4,2 \\
\hline & 27 & CAP 50/70 & 6,8 & 16590 & 20239 & 18,0 & 3,8 \\
\hline & 29 & CAP 50/70 & 7,0 & 17930 & 22395 & 19,9 & 4,4 \\
\hline & 37 & CAP 50/70 + Cal & 6,6 & 16508 & 20387 & 19,0 & 4,1 \\
\hline & 40 & CAP 50/70 + Cal & 6,7 & 14608 & 17832 & 18,1 & 4,2 \\
\hline & 41 & CAP 50/70 + Cal & 6,7 & 13011 & 15997 & 18,7 & 4,1 \\
\hline & 49 & CAP 50/70 + SBS & 7,0 & 11392 & 14040 & 18,9 & 4,1 \\
\hline & 52 & CAP 50/70 + SBS & 6,7 & 12977 & 15906 & 18,4 & 4,1 \\
\hline & 54 & CAP 50/70 + SBS & 7,0 & 13034 & 15506 & 15,9 & 4,1 \\
\hline & 62 & CAP 50/70 + SBS + Cal & 6,7 & 12973 & 16186 & 19,9 & 4,3 \\
\hline & 65 & CAP 50/70 + SBS + Cal & 6,8 & 10946 & 13675 & 20,0 & 4,0 \\
\hline & 66 & $\mathrm{CAP} 50 / 70+\mathrm{SBS}+\mathrm{Cal}$ & 6,2 & 11048 & 13808 & 20,0 & 4,2 \\
\hline
\end{tabular}




\begin{tabular}{|c|c|c|c|c|c|c|c|}
\hline & $\mathbf{C P}$ & Composição & $\begin{array}{l}\text { Vv } \\
(\%)\end{array}$ & $\begin{array}{l}\text { MR25 TOTAL } \\
\text { NCHRP }\end{array}$ & $\begin{array}{c}\text { MR }_{25} \text { INSTANTANEO REAL } \\
\text { NCHRP }\end{array}$ & $\mathbf{R R}_{25}(\%)$ & $\operatorname{ATRASO}_{25}\left(10^{-2} \mathrm{~S}\right)$ \\
\hline \multirow{12}{*}{$\stackrel{0}{\stackrel{0}{2}}$} & 2 & CAP 50/70 + Cal & 7,7 & 7316 & 10379 & 29,52 & 4,7 \\
\hline & 5 & CAP 50/70 + Cal & 7,8 & 6759 & 9664 & 30,06 & 4,6 \\
\hline & 6 & CAP 50/70 + Cal & 7,8 & 5093 & 7337 & 30,58 & 4,6 \\
\hline & 9 & CAP 50/70 & 8,2 & 4131 & 5933 & 30,36 & 4,5 \\
\hline & 10 & CAP 50/70 & 8,4 & 4664 & 6713 & 30,52 & 4,6 \\
\hline & 12 & CAP 50/70 & 8,1 & 5506 & 8011 & 31,27 & 4,7 \\
\hline & 1 sty & CAP 50/70 + SBS + Cal & 7,2 & 5139 & 6937 & 25,93 & 4,5 \\
\hline & 2 sty & $\mathrm{CAP} 50 / 70+\mathrm{SBS}+\mathrm{Cal}$ & 6,7 & 6439 & 8610 & 25,22 & 4,7 \\
\hline & 5 sty & CAP 50/70 + SBS + Cal & 6,7 & 6210 & 8702 & 28,63 & 4,3 \\
\hline & 8 sty & CAP 50/70 + SBS & 8,3 & 4817 & 6701 & 28,12 & 4,5 \\
\hline & 9 sty & CAP 50/70 + SBS & 8,3 & 6414 & 8603 & 25,44 & 4,5 \\
\hline & 10 sty & CAP 50/70 + SBS & 8,2 & 5498 & 7819 & 29,68 & 4,6 \\
\hline \multirow{12}{*}{$\sum_{i}$} & 31 & CAP 50/70 & 6,8 & 5081 & 6979 & 27,19 & 4,5 \\
\hline & 32 & CAP 50/70 & 7,2 & 5793 & 8201 & 29,36 & 4,7 \\
\hline & 33 & CAP 50/70 & 7,0 & 5369 & 7404 & 27,49 & 4,6 \\
\hline & 40 & CAP 50/70 + Cal & 6,7 & 6520 & 8850 & 26,32 & 4,5 \\
\hline & 41 & CAP 50/70 + Cal & 6,6 & 7481 & 10426 & 28,25 & 4,7 \\
\hline & 45 & CAP 50/70 + Cal & 6,4 & 6579 & 9031 & 27,15 & 4,5 \\
\hline & 52 & CAP $50 / 70+$ SBS & 7,1 & 6148 & 8350 & 26,37 & 4,6 \\
\hline & 55 & CAP 50/70 + SBS & 7,1 & 5838 & 7937 & 26,45 & 4,5 \\
\hline & 57 & CAP 50/70 + SBS & 6,3 & 5085 & 6849 & 25,76 & 4,6 \\
\hline & 65 & CAP $50 / 70+\mathrm{SBS}+\mathrm{Cal}$ & 6,5 & 5721 & 7996 & 28,45 & 4,6 \\
\hline & 66 & CAP 50/70 + SBS + Cal & 6,7 & 4968 & 7090 & 29,93 & 4,7 \\
\hline & 67 & CAP 50/70 + SBS + Cal & 6,9 & 5606 & 7848 & 28,57 & 4,6 \\
\hline
\end{tabular}




\begin{tabular}{|c|c|c|c|c|c|c|c|}
\hline & $\mathbf{C P}$ & Composição & $\begin{array}{l}\mathbf{V v} \\
(\%)\end{array}$ & $\begin{array}{l}\text { MR } 40 \text { TOTAL } \\
\text { NCHRP }\end{array}$ & $\begin{array}{c}\text { MR }_{40} \text { INSTANTANEO REAL } \\
\text { NCHRP }\end{array}$ & $\mathbf{R R}_{\mathbf{4 0}}(\%)$ & $\operatorname{ATRASO}_{40}\left(10^{-2} \mathrm{~S}\right)$ \\
\hline \multirow{12}{*}{$\stackrel{0}{i}$} & 1 & CAP 50/70 + Cal & 7,7 & 1872 & 2331 & 19,71 & 5,00 \\
\hline & 5 & CAP 50/70 + Cal & 7,8 & 2229 & 3359 & 33,64 & 5,10 \\
\hline & 6 & CAP 50/70 + Cal & 7,8 & 1133 & 1658 & 31,67 & 4,90 \\
\hline & 7 & CAP 50/70 & 8,6 & 1075 & 1490 & 27,86 & 4,90 \\
\hline & 8 & CAP 50/70 & 8,2 & 972 & 1251 & 22,29 & 5,00 \\
\hline & 9 & CAP 50/70 & 8,2 & 1146 & 1500 & 23,56 & 5,10 \\
\hline & 1 sty & CAP 50/70 + SBS + Cal & 7,2 & 2447 & 3332 & 26,55 & 5,00 \\
\hline & 2 sty & CAP 50/70 + SBS + Cal & 6,7 & 1740 & 2301 & 24,37 & 4,90 \\
\hline & 3 sty & CAP 50/70 + SBS + Cal & 7,0 & 2793 & 3869 & 27,82 & 5,20 \\
\hline & 7 sty & CAP 50/70 + SBS & 8,4 & 1565 & 1883 & 16,9 & 4,80 \\
\hline & 11 sty & CAP 50/70 + SBS & 8,3 & 1657 & 2259 & 26,63 & 5,20 \\
\hline & 12 sty & CAP 50/70 + SBS & 8,2 & 1399 & 1841 & 24,04 & 4,70 \\
\hline \multirow{12}{*}{$\sum_{i=1}^{\infty}$} & 33 & CAP 50/70 & 7,2 & 2029 & 2366 & 14,25 & 5,30 \\
\hline & 34 & CAP 50/70 & 7,0 & 1896 & 2021 & 6,16 & 5,00 \\
\hline & 35 & CAP 50/70 & 6,7 & 2091 & 2709 & 22,81 & 5,00 \\
\hline & 44 & CAP 50/70 + Cal & 6,7 & 2122 & 3012 & 29,54 & 5,10 \\
\hline & 45 & CAP 50/70 + Cal & 6,6 & 2171 & 3152 & 31,1 & 5,20 \\
\hline & 47 & CAP 50/70 + Cal & 6,4 & 2078 & 2757 & 24,63 & 5,10 \\
\hline & 55 & CAP 50/70 + SBS & 7,1 & 1907 & 2710 & 29,61 & 4,70 \\
\hline & 59 & CAP 50/70 + SBS & 7,1 & 2048 & 2742 & 25,33 & 4,80 \\
\hline & 60 & CAP 50/70 + SBS & 7,0 & 2081 & 3013 & 30,94 & 5,20 \\
\hline & 67 & CAP 50/70 + SBS + Cal & 6,5 & 1985 & 2790 & 28,84 & 5,10 \\
\hline & 69 & CAP 50/70 + SBS + Cal & 6,7 & 1985 & 2811 & 29,4 & 4,90 \\
\hline & 70 & CAP 50/70 + SBS + Cal & 6,9 & 1909 & 2687 & 28,96 & 4,90 \\
\hline
\end{tabular}




\begin{tabular}{|c|c|c|c|c|c|c|c|c|}
\hline & $\mathbf{N}^{\circ}$ & $\mathbf{C P}$ & Composiçãa & $\mathbf{V v}$ & $\begin{array}{c}\text { G sat. } \\
(\%)\end{array}$ & $\begin{array}{c}\mathbf{R T}_{\mathbf{G 1}} \\
(\mathbf{M P a})\end{array}$ & $\begin{array}{l}\mathbf{R T}_{\mathbf{G 2}} \\
(\mathrm{MPa})\end{array}$ & $\begin{array}{c}\text { RRT } \\
(\%)\end{array}$ \\
\hline \multirow{24}{*}{ AASHTO } & 1 & 1 & Convencional + Cal & 7,6 & - & 1,55 & - & \multirow{6}{*}{101} \\
\hline & 2 & 2 & Convencional + Cal & 7,7 & - & 1,54 & - & \\
\hline & 3 & 3 & Convencional $+\mathrm{Cal}$ & 7,9 & 79,05 & - & 1,44 & \\
\hline & 4 & 4 & Convencional $+\mathrm{Cal}$ & 7,9 & 72,22 & - & 1,45 & \\
\hline & 5 & 5 & Convencional $+\mathrm{Cal}$ & 7,8 & 75,36 & - & 1,62 & \\
\hline & 6 & 6 & Convencional $+\mathrm{Cal}$ & 7,8 & - & 1,37 & - & \\
\hline & 7 & 7 & Convencional & 8,6 & 77,08 & - & 1,18 & \multirow{6}{*}{83} \\
\hline & 8 & 8 & Convencional & 8,1 & 76,39 & - & 0,99 & \\
\hline & 9 & 9 & Convencional & 8,1 & - & 1,32 & - & \\
\hline & 10 & 10 & Convencional & 8,3 & 76,41 & - & 1,02 & \\
\hline & 11 & 11 & Convencional & 8,1 & - & 1,32 & - & \\
\hline & 12 & 12 & Convencional & 8,1 & - & 1,22 & - & \\
\hline & 13 & 1 sty & Modificado + Cal & 7,2 & 70,57 & - & 1,74 & \multirow{6}{*}{107} \\
\hline & 14 & 2 sty & Modificado + Cal & 6,7 & - & 1,71 & - & \\
\hline & 15 & 3 sty & Modificado + Cal & 7,0 & 78,26 & - & 1,81 & \\
\hline & 16 & 4 sty & Modificado + Cal & 6,5 & - & 1,75 & - & \\
\hline & 17 & 5 sty & Modificado + Cal & 6,7 & - & 1,79 & - & \\
\hline & 18 & 6 sty & Modificado + Cal & 6,8 & 70,47 & - & 2,09 & \\
\hline & 19 & 7 sty & Modificado & 8,3 & 76,44 & - & 1,58 & \multirow{6}{*}{105} \\
\hline & 20 & 8 sty & Modificado & 8,2 & 71,62 & - & 1,74 & \\
\hline & 21 & 9 sty & Modificado & 8,3 & 74,18 & - & 1,65 & \\
\hline & 22 & 10 sty & Modificado & 8,2 & - & 1,59 & - & \\
\hline & 23 & 11 sty & Modificado & 8,2 & - & 1,62 & - & \\
\hline & 24 & 12 sty & Modificado & 8,1 & - & 1,53 & - & \\
\hline
\end{tabular}




\begin{tabular}{|c|c|c|c|c|c|c|c|c|}
\hline & $\mathbf{N}^{\circ}$ & $\mathbf{C P}$ & Composição & $\mathbf{V v}$ & $\begin{array}{c}\text { G sat. } \\
(\%)\end{array}$ & $\begin{array}{c}\mathbf{R T}_{\mathbf{G 1}} \\
(\mathbf{M P a})\end{array}$ & $\begin{array}{c}\mathbf{R T}_{\mathbf{G 2}} \\
(\mathbf{M P a})\end{array}$ & $\begin{array}{c}\text { RRT } \\
(\%)\end{array}$ \\
\hline \multirow{24}{*}{ ASTM } & 25 & 25 & Convencional & 6,9 & 73,96 & - & 0,76 & \multirow{6}{*}{73} \\
\hline & 26 & 26 & Convencional & 6,4 & - & 1,45 & - & \\
\hline & 27 & 27 & Convencional & 6,8 & - & 1,46 & - & \\
\hline & 28 & 28 & Convencional & 6,6 & - & 1,32 & - & \\
\hline & 29 & 29 & Convencional & 6,9 & 77,48 & - & 1,01 & \\
\hline & 30 & 30 & Convencional & 7,1 & 78,40 & - & 1,31 & \\
\hline & 31 & 37 & Convencional + Cal & 6,6 & - & 1,33 & & \multirow{6}{*}{108} \\
\hline & 32 & 38 & Convencional + Cal & 6,7 & 73,61 & - & 1,52 & \\
\hline & 33 & 39 & Convencional + Cal & 6,8 & 70,29 & - & 1,52 & \\
\hline & 34 & 40 & Convencional + Cal & 6,7 & 71,02 & - & 1,50 & \\
\hline & 35 & 41 & Convencional + Cal & 6,7 & - & 1,29 & - & \\
\hline & 36 & 42 & Convencional $+\mathrm{Cal}$ & 6,4 & - & 1,57 & - & \\
\hline & 37 & 49 & Modificado & 7,0 & - & 1,61 & - & \multirow{6}{*}{110} \\
\hline & 38 & 50 & Modificado & 7,0 & 70,23 & - & 1,89 & \\
\hline & 39 & 51 & Modificado & 6,9 & - & 1,83 & - & \\
\hline & 40 & 52 & Modificado & 6,6 & - & 1,75 & - & \\
\hline & 41 & 53 & Modificado & 7,2 & 71,02 & - & 1,94 & \\
\hline & 42 & 54 & Modificado & 6,9 & 70,13 & - & 1,87 & \\
\hline & 43 & 61 & Modificado + Cal & 6,2 & - & 1,58 & - & \multirow{6}{*}{104} \\
\hline & 44 & 62 & Modificado + Cal & 6,7 & 72,89 & - & 1,62 & \\
\hline & 45 & 63 & Modificado + Cal & 6,6 & - & 1,65 & - & \\
\hline & 46 & 64 & Modificado + Cal & 6,9 & 70,42 & - & 1,74 & \\
\hline & 47 & 65 & Modificado + Cal & 6,7 & 70,07 & - & 1,69 & \\
\hline & 48 & 66 & Modificado + Cal & 6,2 & - & 1,61 & - & \\
\hline
\end{tabular}




\section{ANEXO II}

Relatório: Significância, efeitos principais e de interacão de propriedades originais das misturas testadas 
Relatório Anova Minitab

Significância, efeitos principais e de interação de propriedades originais das misturas testadas

Modelo Linear geral: MR (MPa); RT (MPa) versus ASFALTO; ADITIVO; ...

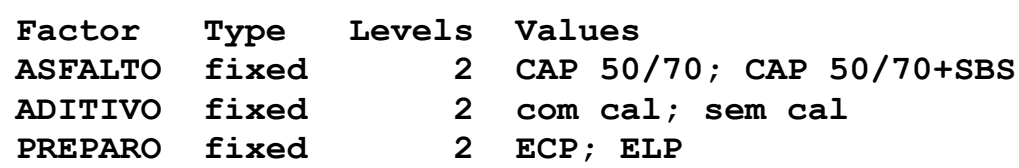

Análise de Variância para MR (MPa), usando soma do quadrados ajustados para testes

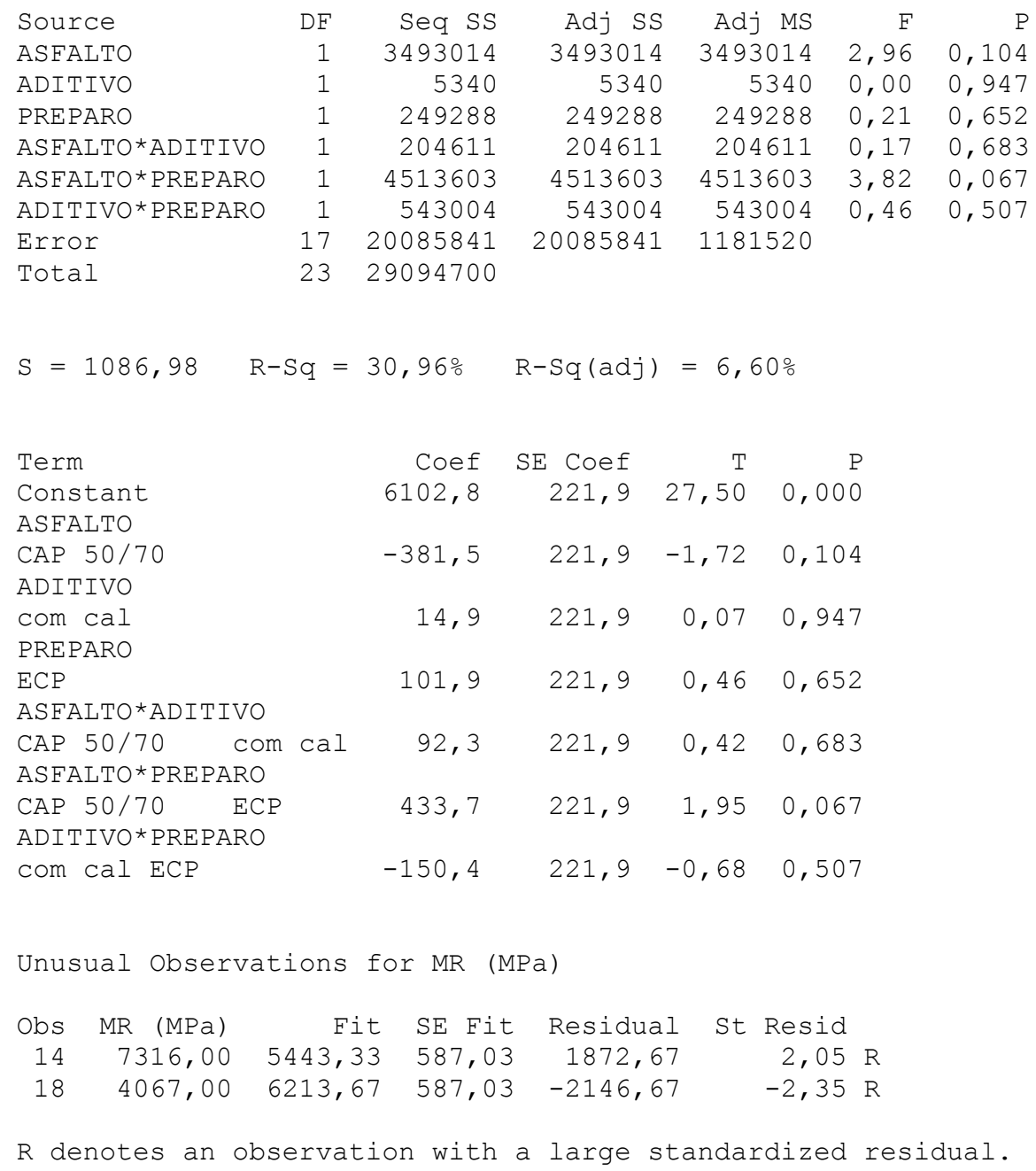

Análise de Variância para RT (MPa), usando soma do quadrados ajustados para testes $\begin{array}{lrrrrrr}\text { Source } & \text { DF } & \text { Seq SS } & \text { Adj SS } & \text { Adj MS } & \text { F } & \text { P } \\ \text { ASFALTO } & 1 & 0,448267 & 0,448267 & 0,448267 & 62,52 & 0,000\end{array}$ 


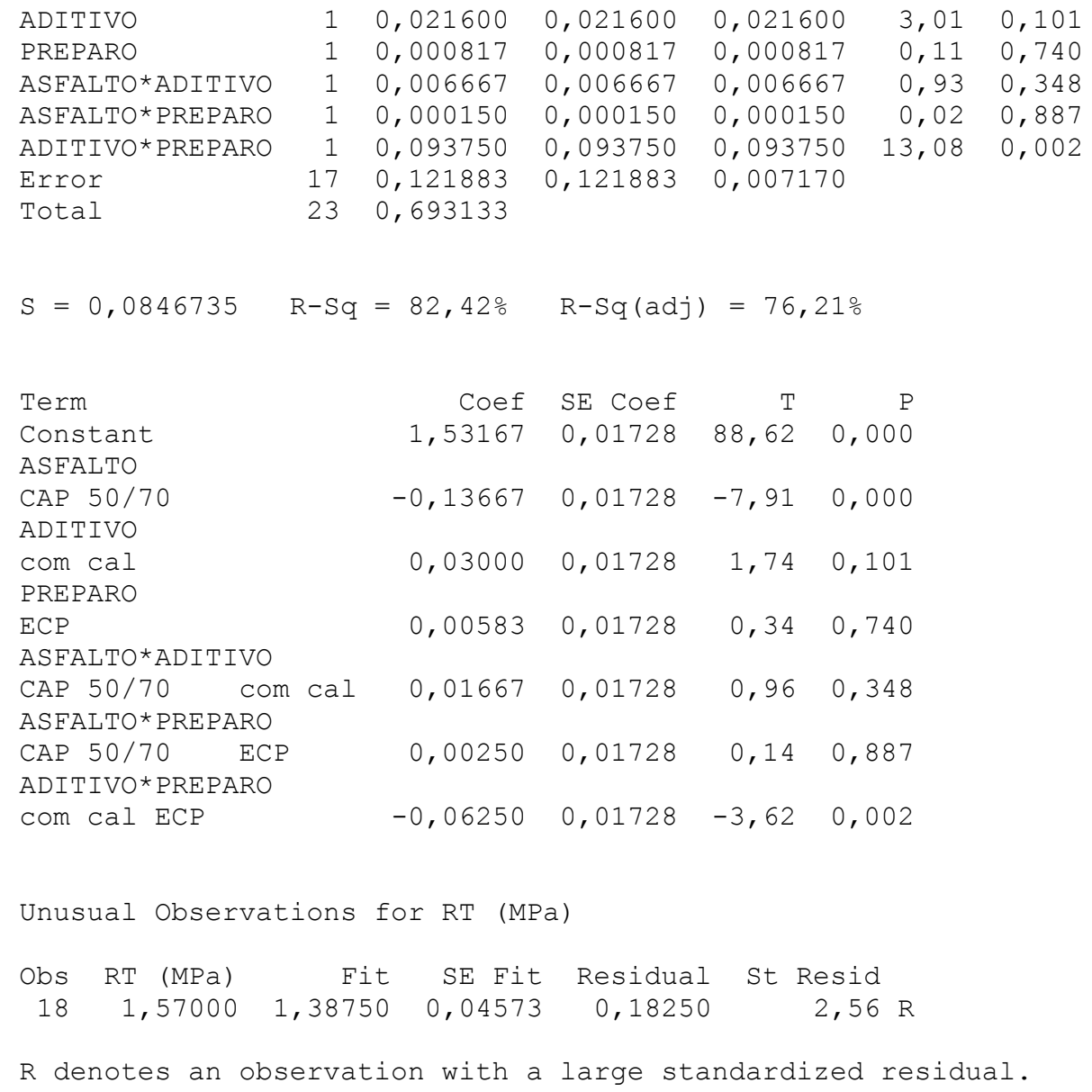

Média mínimos quadrados

$\begin{array}{lrrrr} & --- \text { MR } & \text { (MPa) }---- & ---R T & \text { (MPa) }-- \\ \text { ASFALTO } & \text { Mean } & \text { SE Mean } & \text { Mean } & \text { SE Mean } \\ \text { CAP } 50 / 70 & 5721,25 & 313,783 & 1,40 & 0,024 \\ \text { CAP 50/70+SBS } & 6484,25 & 313,783 & 1,67 & 0,024 \\ \text { ADITIVO } & & & & \\ \text { COm cal } & 6117,67 & 313,783 & 1,56 & 0,024 \\ \text { sem cal } & 6087,83 & 313,783 & 1,50 & 0,024 \\ \text { PREPARO } & & & & \\ \text { ECP } & 6204,67 & 313,783 & 1,54 & 0,024 \\ \text { ELP } & 6000,83 & 313,783 & 1,53 & 0,024\end{array}$



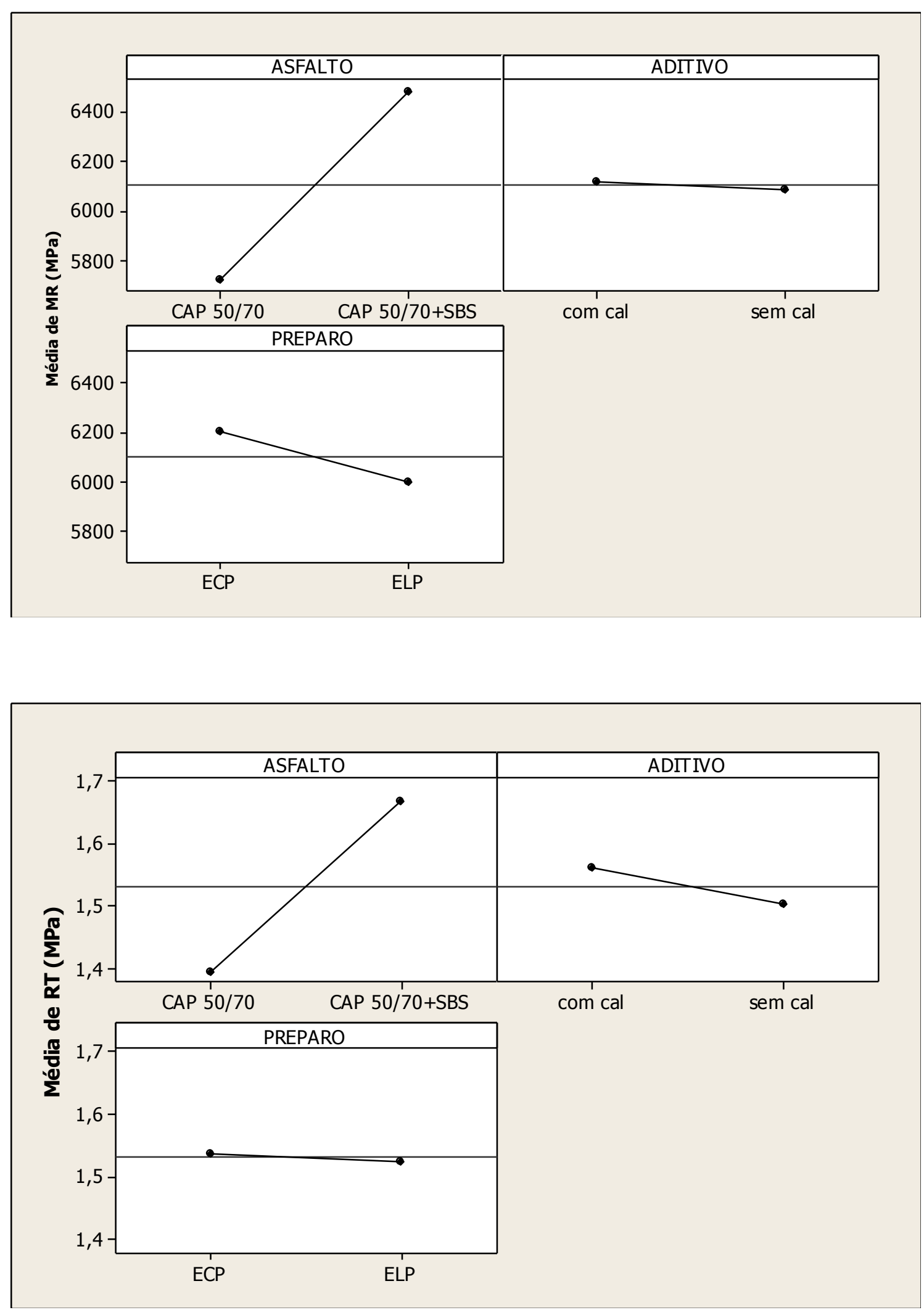


\title{
Relatório Anova Minitab
}

Significância, efeitos principais e de interação de
propriedades após condicionamento das misturas testadas

\author{
Modelo linear geral: RT (MPa) versus ASFALTO; ADITIVO; ...

$\begin{array}{llrl}\text { Factor } & \text { Type } & \text { Levels } & \text { Values } \\ \text { ASFALTO } & \text { fixed } & 2 & \text { CAP } 50 / 70 ; \text { CAP } 50 / 70+\text { SBS } \\ \text { ADITIVO } & \text { fixed } & 2 \text { COm Cal; sem cal } \\ \text { PREPARO } & \text { fixed } & 2 \text { ECP; ELP } \\ \text { CONDICIONAMENTO } & \text { fixed } & 2 \text { Com; sem }\end{array}$

\section{Análise de Variância para RT (MPa), usando soma do quadrados ajustados para testes}

$\begin{array}{lrrrrrr}\text { SourCe } & \text { DF } & \text { Seq SS } & \text { Adj SS } & \text { Adj MS } & \text { F } & \text { P } \\ \text { ASFALTO } & 1 & 1,80575 & 1,80575 & 1,80575 & 90,74 & 0,000 \\ \text { ADITIVO } & 1 & 0,09992 & 0,09992 & 0,09992 & 5,02 & 0,031 \\ \text { PREPARO } & 1 & 0,00092 & 0,00092 & 0,00092 & 0,05 & 0,831 \\ \text { CONDICIONAMENTO } & 1 & 0,00035 & 0,00035 & 0,00035 & 0,02 & 0,895 \\ \text { ASFALTO*ADITIVO } & 1 & 0,41255 & 0,41255 & 0,41255 & 20,73 & 0,000 \\ \text { ASFALTO*PREPARO } & 1 & 0,00060 & 0,00060 & 0,00060 & 0,03 & 0,863 \\ \text { ASFALTO*CONDICIONAMENTO } & 1 & 0,15755 & 0,15755 & 0,15755 & 7,92 & 0,008 \\ \text { ADITIVO*PREPARO } & 1 & 0,04025 & 0,04025 & 0,04025 & 2,02 & 0,163 \\ \text { ADITIVO*CONDICIONAMENTO } & 1 & 0,01172 & 0,01172 & 0,01172 & 0,59 & 0,448 \\ \text { PREPARO*CONDICIONAMENTO } & 1 & 0,00010 & 0,00010 & 0,00010 & 0,01 & 0,943 \\ \text { ErrOr } & 37 & 0,73633 & 0,73633 & 0,01990 & & \\ \text { TotaI } & 47 & 3,26605 & & & & \end{array}$

$\mathrm{S}=0,141070 \quad \mathrm{R}-\mathrm{Sq}=77,46 \% \mathrm{R}-\mathrm{Sq}(\operatorname{adj})=71,36 \%$

\begin{tabular}{|c|c|c|c|c|}
\hline Term & Coef & SE Coef & $\mathrm{T}$ & \\
\hline $\begin{array}{l}\text { Constant } \\
\text { ASFALTO }\end{array}$ & & 0,02036 & 75,09 & 0,000 \\
\hline $\begin{array}{l}\text { CAP } 50 / 70 \\
\text { ADITIVO }\end{array}$ & $-0,19396$ & 0,02036 & $-9,53$ & 0,000 \\
\hline $\begin{array}{l}\text { om cal } \\
\text { REPARO }\end{array}$ & 0,04562 & 0,02036 & 2,24 & 0,031 \\
\hline $\begin{array}{l}\text { CP } \\
\text { ONDICIONAME }\end{array}$ & 0,00437 & 0,02036 & 0,21 & 0,831 \\
\hline $\begin{array}{l}\text { om } \\
\text { SFALTO*ADITIVO }\end{array}$ & $-0,00271$ & 0,02036 & $-0,13$ & 0,895 \\
\hline $\begin{array}{l}\text { AP 50/70 com cal } \\
\text { SFALTO*PREPARO }\end{array}$ & 0,09271 & 0,02036 & 4,55 & 0,000 \\
\hline $\begin{array}{l}\text { AP } 50 / 70 \quad \text { ECP } \\
\text { SEALTO*CONDICIONAME }\end{array}$ & $-0,00354$ & 0,02036 & $-0,17$ & 0,863 \\
\hline $\begin{array}{l}\text { AP } 50 / 70 \quad \text { COM } \\
\text { DITIVO*PREPARO }\end{array}$ & $-0,05729$ & 0,02036 & $-2,81$ & 0,008 \\
\hline $\begin{array}{l}\text { m Cal ECP } \\
\text { ITIVO*CONDICIONAME }\end{array}$ & $-0,02896$ & 0,02036 & $-1,42$ & 0,163 \\
\hline $\begin{array}{l}\text { m cal com } \\
\text { REPARO*CONDICIONAME }\end{array}$ & 0,01562 & 0,02036 & 0,77 & 0,448 \\
\hline com & $-0,00146$ & 036 & $-0,07$ & 0,94 \\
\hline
\end{tabular}


Unusual Observations for $\mathrm{RT}$ (MPa)

$\begin{array}{rrrrrr}\text { Obs } & \text { RT (MPa) } & \text { Fit } & \text { SE Fit } & \text { Residual } & \text { St Resid } \\ 25 & 0,76000 & 1,14937 & 0,06753 & -0,38937 & -3,14 \mathrm{R} \\ 47 & 2,08000 & 1,77354 & 0,06753 & 0,30646 & 2,47 \mathrm{R}\end{array}$

$\mathrm{R}$ denotes an observation with a large standardized residual.

Média mínimos quadrados para RT (MPa)

$\begin{array}{lrr}\text { ASFALTO } & \text { Mean } & \text { SE Mean } \\ \text { CAP 50/70 } & 1,335 & 0,02880 \\ \text { CAP 50/70+SBS } & 1,723 & 0,02880 \\ \text { ADITIVO } & & \\ \text { COm cal } & 1,575 & 0,02880 \\ \text { sem cal } & 1,483 & 0,02880 \\ \text { PREPARO } & & \\ \text { ECP } & 1,533 & 0,02880 \\ \text { ELP } & 1,525 & 0,02880 \\ \text { CONDICIONAME } & & \\ \text { COm } & 1,526 & 0,02880 \\ \text { sem } & 1,532 & 0,02880\end{array}$

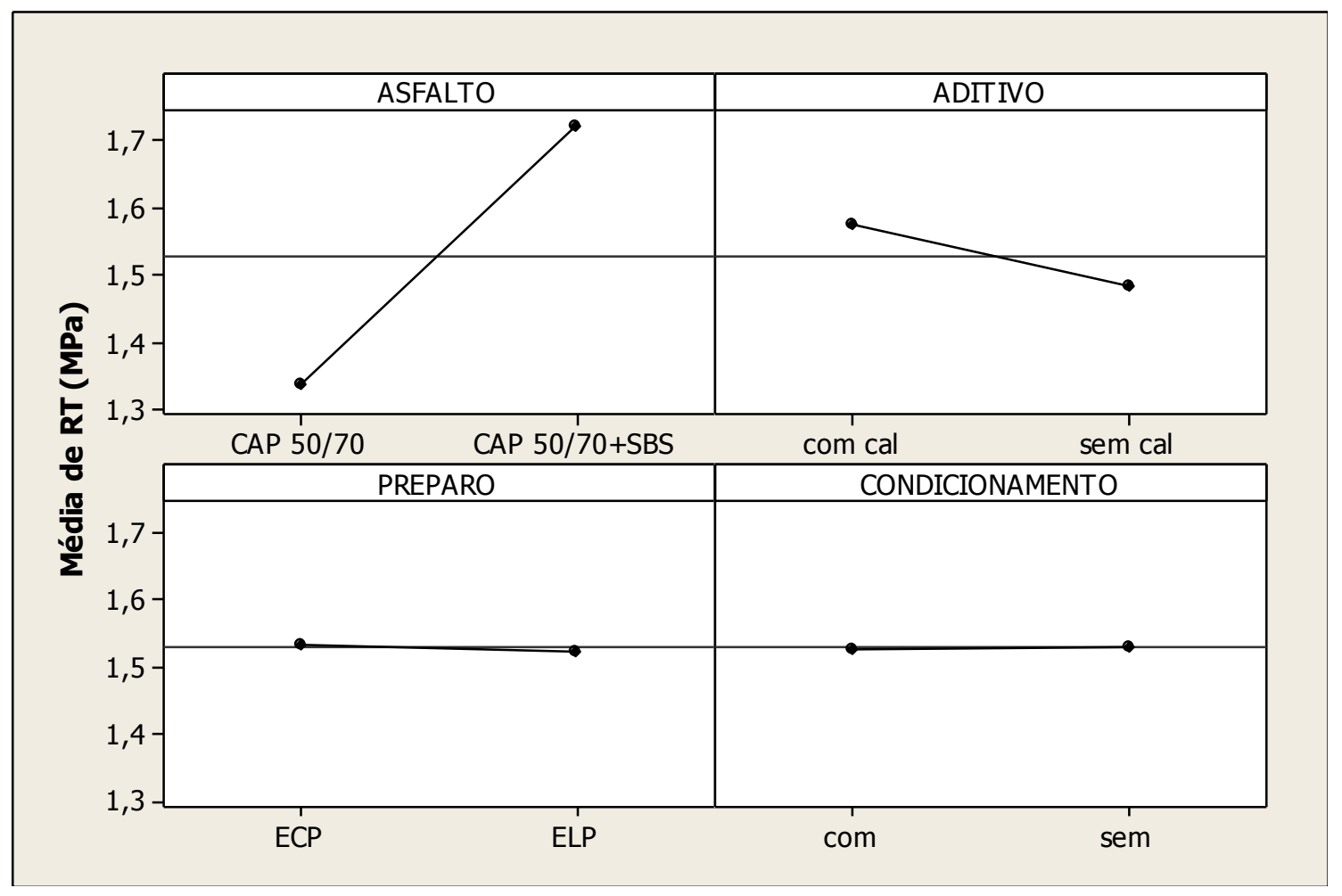




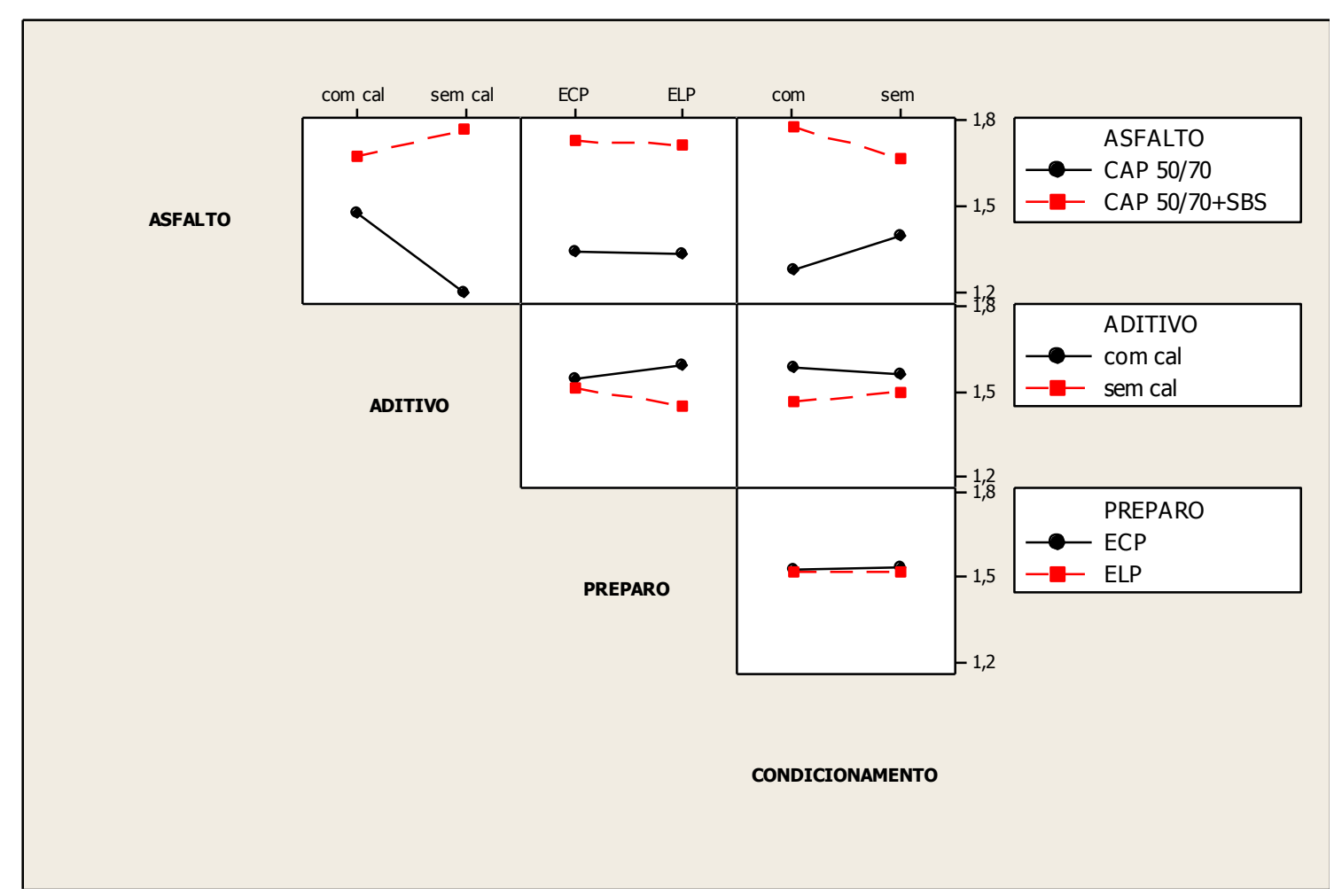

